\title{
CONTRIBUTION TO A BIBLIOGRAPHY OF RECENT TEXAS MAMMALS 1981-1990
}

J. Knox Jones, Jr., Stephen Demarais, and Chris T. McAllister

Special Publications, The Ml'seuil

TEXAS TECH UNIVERSITY

NUMBER 38 



\title{
CONTRIBUTION TO A BIBLIOGRAPHY OF RECENT TEXAS MAMMALS, 1981-1990
}

\author{
J. Knox Jones, Jr., Stephen Demarais, \\ and Chris T. McAllister
}




\title{
Special Publications, The Museum \\ TEXAS TECH UNIVERSITY \\ NUMBER 38
}

\author{
J. Knox Jones, Jr. \\ Series Editor
}

\section{Published 5 May 1995 \\ Copyright 1995 Texas Tech University Press}

All rights reserved. No portion of this book may be reproduced in any form or by any means, including electronic storage and retrieval systems, except by explicit, prior written permission of the publisher.

Special Publications of The Museum are numbered serially and published on an irregular basis, Institutions interested in exchanging publications should address the Exchange Librarian at Texas Tech University.

ISSN 0149-1768

ISBN 0-89672-351-8

Texas Tech University Press

P. O. Box 41037

Lubbock, Texas 79409-1037 USA 


\section{Contents}

INTRODUCTION $\quad 5$

General REFERENCES

Biodiversity, Faunal Studies, Regional Lists, AND ZoOgEOGRAPHY 7

$\begin{array}{lr}\text { DIDELPHIMORPHIA (MARSUPIALIA) } & 10\end{array}$

$\begin{array}{lr}\text { INSECTIVORA } & 10 \\ \text { CHIROPTERA } & 10\end{array}$

$\begin{array}{lr}\text { CHIROPTERA } & 10\end{array}$

XeNARTHRA (EDENTATA) 12

LAGOMORPHA $\quad 12$

RODENTIA $\quad 13$

$\begin{array}{lr}\text { Cetacea } & 21 \\ \text { CarnivOra } & 22\end{array}$

CARnivora $\quad 22$

$\begin{array}{lr}\text { SIRENIA } & 27\end{array}$

ARTIODACTYLA $\quad 28$

PARASITES AND DISEASES $\quad 56$

OTHER STUDIES $\quad 63$

Literature Cited $\quad 64$ 



\section{INTRODUCTION}

Raun (1962), Jones and Homan (1976), and Jones et al. (1985) have prepared bibliographies for the Recent mammals of Texas that cover the time period through the year 1980. The current contribution includes works published in the 10 years 1981 through 1990, and thus provides, with the three papers cited above, an index through the close of the last decade to the literature on modern mammals of Texas, a biologically important state that bridges the vast region between deciduous and conferous forests of the southeastern United States and the arid and mountainous Southwest. That the relevant literature on Texas continues to increase each year is attested to by the 21 pages covering the 1961-1970 list as compared to the size of the present undertaking.

In preparing a bibliography of this sort, certain decisions must be made a priori as to what kinds of material will and will not be included. As a general rule, we did not include processed literature (that is, literature produced directly from typescript) unless we felt the contribution to be of a level of significance that interested mammalogists should be aware of it. All citations to such works are labeled as "processed." Secondly, we did not include material actually published after the end of 1990 (if we could establish that fact) even if it appeared in a volume labeled as "1990" or earlier. And thirdly, we did not canvass nontechnical sources except the serial publication Texas Parks and Wildlife, from which the more important semitechnical articles on mammals were admitted to the list.

Other organizational features of import are: 1) publications listed, excepting some included in the section entitled General References, are only those in which there is a clear reference to Texas (although we did cite numbers of Mammalian Species, published by the American Society of Mammalogists and intended as concise summaries of the biology of individual species of mammals, that pertain to taxa occurring in Texas); 2) citations to the serial literature include only volume number and pagination unless individual numbers of volumes were separately paged; 3 ) references dealing with fossil mammals were excluded unless Recent material also was recorded or used in comparisons with fossil specimens; 4) citations ordinarily appear exactly as published (with the exception that only proper nouns are capitalized), but an occasional punctuation mark has been added or other minor change made in the interest of clarity or proper English usage.

As in the earlier bibliographies by Jones and Homan (op. cit.) and Jones et al. (op. cit.), this one is organized in 13 sections: one including general references; one encompassing biodiversity and faunal studies and related works; nine sections headed by a mammalian ordinal name; one on parasites and diseases; and a terminal section for miscellaneous contributions in which Texas mammals are mentioned. Because the bibliography is relatively short, we have not attempted to cross-list references, but have entered them in what we considered to be the section most appropriate to the subject matter. For example, a paper involving distributional notes on two or 
more species belonging to different orders has been treated as a "regional list," whereas a similar one involving comments on several species of Rodentia will appear in the section headed by that ordinal name. A publication on ectoparasites of white-tailed deer will be found in the section dealing with parasites and diseases, not included under Artiodactyla. A few papers on feral domesticated mammals, such as several dealing with brucellosis infections or home ranges after supplemental feeding in wild swine, were knowingly excluded. Virtually all titles have been checked personally by one or more of the authors; the few not seen were taken from citations found in other works. Despite all efforts, some publications that might have been included possibly have been overlooked. A few omitted from earlier compilations are listed here.

We are grateful to several colleagues and students for assisting us in preparation of this manuscript. Most importantly, we should mention E. J. Edmunds, R. W. Manning, F. B. Stangl, Jr., and K. T. Wilkins. 


\section{General References}

ANDERSON, S., AND J. K. JONES, JR. 1984. Orders and families of Recent mammals of the world. John Wiley \& Sons, New York, xii +686 pp.

ARMSTRONG, D. M., J. R. ChOATE, AND J. K. JONES, JR. 1986. Distributional patterns of mammals of the plains states. Occas. Papers Mus., Texas Tech Univ., 105:1-27.

Baccus, J. T. (ed.). 1982. Texas wildlife resources and land use. Texas Chap. Wildlife Soc., 199 pp.

CAIRE, W., J. D. TYlER, B. P. Glass, AND MARES. 1989. Mammals of Oklahoma. Univ. Oklahoma Press, Norman, xiii +567 pp.

Chapman, J. A., And G. A. Feldhamer (eds.). 1982. Wild mammals of North America. The Johns Hopkins Univ. Press, Baltimore, xiii +1147 pp.

DeBlase, A. F., AND R. E. MARTIN. 1980. A manual of mammalogy with keys to families of the world. Wm. C. Brown Co., Dubuque, Iowa, xii + 436 pp. [dated 1981 but first distributed in December 1980].

FindLeY, J. S. 1987. The natural history of New Mexican mammals. Univ. New Mexico Press, Albuquerque, xii $+164 \mathrm{pp}$.

HaLl, E. R. 1981. Mammals of North America. John Wiley \& Sons, New York, 2nd ed., 1:xviii + $1-600+90,2: \mathrm{viii}+601-1181+90$.

HofFMeISTER, D. F. 1986. Mammals of Arizona. Univ. Arizona Press, Tucson, xx +602 pp.

JoNeS, J. K., JR., D. M. ARMSTRONG, AND J. R. ChOATE. 1985. Guide to mammals of the plains states. Univ. Nebraska Press, Lincoln, xix $+371 \mathrm{pp}$.

JoNES, J. K., JR., C. J. YounG, AND D. J. SChmidLY. 1985. Contribution to a bibliography of Recent Texas mammals, 1971-1980. Occas. Papers Mus., Texas Tech Univ., 95:1-44.

Jones, J. K., JR., D. C. Carter, H. H. Genoways, R. S. Hoffmann, and D. W. Rice. 1982. Revised checklist of North American mammals north of Mexico, 1982. Occas. Papers Mus., Texas Tech Univ., 80:1-22.

Jones, J. K., JR., D. C. Carter, H. H. Genoways, R. S. Hoffmann, D. W. Rice, and C. Jones. 1986. Revised checklist of North American mammals north of Mexico, 1986. Occas. Papers Mus., Texas Tech Univ., 107:1-22.

NovaK, M., J. A. BAKER, M. E. OBbARD, AND B. MALLOCH (eds.). 1987. Wild furbearer management and conservation in North America. Ministry Nat. Res. Ontario, xviii $+1150 \mathrm{pp}$.

NowaK, R. M., AND J. L. PARADISO. 1983. Walker's mammals of the world. Johns Hopkins Univ. Press., Baltimore, 4th ed., 1:x liv + 1-568 + x l vii- 1 xi and 2: viii + 569-1362 + xi-xxv.

OWEN, R. D., AND G. D. SCHNELL. 1989. Oklahoma immunology: an annotated bibliography and checklist. Univ. Oklahoma Press, Norman, $x+230 \mathrm{pp}$.

SCHMIDLY, D. J., AND J. K. JONES, JR. 1984. Holotypes of Recent mammals in Texas natural history collections. Occas. Papers Mus., Texas Tech Univ., 92:1-13.

Vaughan, T. A. 1986. Mammalogy. Saunders College Publishing, Philadelphia, 3rd ed., vii + $576 \mathrm{pp}$.

\section{Biodiversity, Faunal Studies, Regional Lists, and Zoogeography}

BAKER, R. H. 1990. Future prospects for depletion of mammalian populations in the Chihuahuan Desert region. Pp. 71-79, in Third symposium on resources of the Chihuahuan Desert region (A. M. Powell et al., eds.), Chihuahuan Desert Res. Inst., Alpine, Texas, viii + 191 pp.

BASKIN, C., AND A. ChANEY. 1985. Vertebrate populations in ungrazed and grazed oak mottes. Caesar Kleberg Res. Prog. Wildlife Ecol., Ann. Rept. Texas Agric. Exp. Sta., p. 10.

Bolen, E. G., L. M. SMITH, AND H. L. SChramm, JR. 1989. Playa lakes: prairie wetlands of the Southern High Plains. Bioscience, 39:615-623. 
Chapman, B. R., AND S. G. SPEnCER. 1987. Distributional records for six Texas mammals. Texas J. Sci., 39:379-380.

ChOATE, L. L., AND J. K. JONES, JR. 1989. Systematics, biogeographical relationships, and natural history of mammals on the Llano Estacado, Texas and New Mexico. Welder Wildlife Found. Biennial Rept., p. 12.

Cleveland, A. G., J. T. Baccus, And E. G. Zimmerman. 1984. Distributional records and notes for nine species of mammals in eastern Texas. Texas J. Sci., 35:323-326.

DALQUEST, W. W., AND N. V. HoRNER. 1984. Mammals of north-central Texas. Midwestern Univ. Press, Wichita Falls, Texas, 261 pp.

DALQUeST, W. W., AND F. B. STANGL, JR. 1984. Late Pleistocene and early Recent mammals from Fowlkes Cave, southern Culberson County, Texas. Pp. 432-455, in Contributions in Quaternary vertebrate paleontology ... (H. H. Genoways and M. R. Dawson, eds.), Spec. Publ. Carnegie Mus. Nat. Hist., 8:v + 1-538.

- 1986. Post-Pleistocene mammals of the Apache Mountains, Culberson County, Texas, with comments on zoogeography of the Trans-Pecos Front Range. Occas. Papers Mus., Texas Tech Univ., 104:1-35.

DAlquest, W. W., F. B. StANGL, JR., AND J. K. JoneS, JR. 1990. Mammalian zoogeography of a Rocky Mountain-Great Plains interface in New Mexico, Oklahoma, and Texas. Spec. Publ. Mus., Texas Tech Univ., 34:1-78.

DiCKSON, J. G., AND J. H. Williamson. 1988. Small mammals in streamside management zones in pine plantations. Pp. 375-378, in Management of amphibians, reptiles, and small mammals in North America (R. C. Szaro, K. E. Severson, and D. R. Patton, tech. coordinators), USDA Forest Serv., Gen. Tech. Rept., RM-166:1-458.

FleEt, R. R., AND J. G. Dickson. 1984. Small mammals in two adjacent forest stands in East Texas. Proc. Workshop Manag. Nongame Species Ecol. Communities (W. C. McComb, ed.), Univ. Kentucky, Lexington, pp. 264-269.

Garner, H. W., T. G. JoY, K. D. Huckabee, AND R. M. PitTs. 1990. Additional distributional records of mammals along the boundary of the Kansan-Texan biotic provinces in northcentral Texas. Texas J. Sci., 42:308-310.

GoETZE, J. R., AND L. L. ChOATE. 1987. Distributional notes on four species of Texas mammals. Texas J. Sci., 39:380-381.

Graham, R. W., H. A. Semken, JR., AND M. A. Graham (eds.). 1987. Late Quaternary mammalian biogeography and environments of the Great Plains and prairies. Sci. Papers Illinois State Mus, , 22:xiv + 1-491.

Grant, W. E., P. E. CARothers, AND L. A. GidLEY. 1985. Small mammal community structure in the postoak savanna of east-central Texas. J. Mamm., 66:589-594.

Gust, D. A., AND D. J. SChMidLY. 1986. Small mammal populations on reclaimed strip-mined areas in Freestone County, Texas. J. Mamm., 67:214-217.

Guthery, F. S. 1981. Playa basins and resident wildlife in the Texas Panhandle. Proc. Playa Lake Symp., U.S. Fish Wildlife Serv., pp. 47-51.

HARRIS, A. H. 1990. Fossil evidence bearing on southwestern mammalian biogeography. J. Mamm., 71:219-229.

Hollander, R. R., C. Jones, J. K. Jones, JR., AND R. W. Manning. 1990. Preliminary analysis of the effects of the Pecos River on geographic distribution of small mammals in western Texas. J. Big Bend Stud., 2:97-107.

Hollander, R. R., C. Jones, R. W. Manning, AND J. K. Jones, JR. 1987. Distributional notes on some mammals from the Edwards Plateau and adjacent areas of south-central Texas. Occas. Papers Mus., Texas Tech Univ., 110:1-10. 
Hollander, R. R., J. K. Jones, JR., R. W. MANNING, AND C. Jones. 1987. Noteworthy records of mammals from the Texas Panhandle. Texas J. Sci., 39:97-102.

JAHRSDOERFER, S. E., AND D. M. LESLIE, JR. 1980. Tamaulipan brushland in the lower Rio Grande Valley of South Texas: description, human impacts, management options. Biol. Rept., U. S. Fish Wildlife Serv., 88(36):viii + 1-63.

JoNES, C., R. D. SUTTKUS, AND M. A. Bogan. 1987. Notes on some mammals of north-central Texas. Occas. Papers Mus., Texas Tech Univ., 115:1-21.

JONES, J. K., JR., C. JONES, AND D. J. SCHMIDLY. 1988. Annotated checklist of Recent land mammals of Texas. Occas. Papers Mus., Texas Tech Univ., 119:1-26.

JONES, J. K., JR., R. W. MANNING, R. R. HollandER, AND C. Jones. 1987. Annotated checklist of Recent mammals of northwestern Texas. Occas. Papers Mus., Texas Tech Univ., 111:1-14.

JONES, J. K., JR., R. W. MANNING, C. JONES, AND R. R. HollandeR. 1988. Mammals of the northern Texas Panhandle. Occas. Papers Mus., Texas Tech Univ., 126:1-54.

Lehouerou, H. N., R. A. Bingham, AND H. Jensen. 1984. Survey of wildlife habitat in South Texas. Caesar Kleberg Res. Prog. Wildlife Ecol., Ann. Rept. Texas Agric. Exp. Sta., pp. 3-4.

LUNDELIUS, E. L., JR. 1984. A late Pleistocene mammalian fauna from Cueva Quebrada, Val Verde County, Texas. Pp. 456-481, in Contributions in Quaternary vertebrate paleontology ... (H. H. Genoways and M. R. Dawson, eds.), Spec. Publ. Carnegie Mus. Nat. Hist., 8:v + 1-538.

NAGENDRAN, M., AND L. D. FLAKE. 1985. Impact of grazing systems on rodent and cottontail rabbit populations. Welder Wildlife Found. Biennial Rept., p. 9.

OWEN, J. G. 1990. Patterns of mammalian species richness in relation to temperature, productivity, and variance in elevation. J. Mamm., 71:i-13.

Pesaturo, R. J., J. K. Jones, JR., R. W. Manning, And C. Jones. 1990. Mammals of the Muleshoe Sandhills, Bailey, Hale, and Lamb counties Texas. Occas. Papers Mus., Texas Tech Univ., 136:1-32.

PITTS, R. M. 1982. Breeding period of the least shrew (Cryptotis parva (Say)) and new localities of some cricetid rodents in Texas. Texas J. Sci., 34:192.

SChmidLy, D. J. 1983. Texas mammals east of the Balcones Fault Zone. Texas A\&M Univ. Press, College Station, $x$ viii $+400 \mathrm{pp}$.

1984a. The furbearers of Texas. Bull. Texas Parks Wildlife Dept., 111:viii +1-55.

1984b. Texas mammals: diversity and geographic distribution. Pp. 13-25, in Protection of Texas natural diversity: an introduction for natural resource planners and managers (E. G. Carls and J. Neal, eds.), Bull. Texas Agric. Exp. Sta., College Station, MP-1557:iii +60 .

Severinghaus, W. D., and W. D. Goran. 1982. Notes on the distribution of some birds and mammals in central Texas. Texas J. Sci., 34:92-94.

Simpson, L. A., AND T. C. MAxwell. 1989. The mammal fauna of Coke County, Texas. Texas J. Sci., 41:177-192.

STANGL, F. B., JR., S. KaSPER, AND T. S. SChAFER. 1989. Noteworthy range extensions and marginal distributional records for five species of Texas mammals. Texas J. Sci., 42:436-437.

Talbott-McCall, T., A. Tipton, and J. H. Rappole. 1987. Status review of terrestrial mammals in Texas. Caesar Kleberg Res. Prog. Wildlife Ecol., Ann. Rept. Texas Agric. Exp. Sta., p. 36.

VAN DEVENDER, T. R., G. L. BRADley, AND A. H. HaRRIS. 1987. Late Quaternary mammals from the Hueco Mountains, El Paso and Hudspeth counties, Texas. Southwestern Nat., 32:179-195. 
WAUER, R. H. 1986. Parks and other reserves as islands of protection with special reference to the Chihuahuan Desert. Pp. 150-158, in Invited papers from the second symposium on resources of the Chihuahuan Desert region (J. C. Barlow, A. M. Powell, and B. N. Timmermann, eds.), Chihuahuan Desert Res. Inst., Apline, Texas, vii + 172 pp.

Whiting, JR., R.M., AND R. R. FLEET. 1987. Bird and small mammal communities of loblollyshortleaf pine strands in east Texas. Proc. Southern Eval. Proj. Workshop, Long Beach, Mississippi, pp. 49-66.

WILKINS, K. T. 1982. Highways as barriers to rodent dispersal. Southwestern Nat., 27:459-460.

\section{DidelPhimorPhia (Marsupialia)}

Moore, D. A. 1984. A simple collection technique for blood collection in the oppossum (Didelphis virginiana). Lab. Anim. 18:52-54.

\section{INSECTIVORA}

CHOATE, L. L. 1990. First record of the mole, Scalopus aquaticus, on the Llano Estacado of western Texas. Texas J. Sci., 42:207.

Formanowicz, D. R., JR., P. J. Bradley, AND E. D. Brodie, JR. 1989. Food hoarding by the least shrew (Cryptotis parva): intersexual and prey type effects. Amer. Midland Nat., 122:26-33.

George, S. B., J. R. ChoATE, AND H. H. Genoways. 1981. Distribution and taxonomic status of Blarina hylophaga Elliot (Insectivora: Soricidae). Ann. Carnegie Mus., 50:493-513.

George, S. B., H. H. Genoways, J. R. ChOATE, AND R. J. BAKER. 1982. Karyotypic relationships within the short-tailed shrews, genus Blarina. J. Mamm., 63:639-645.

OWEN, R. D., AND M. J. Hamilton. 1986. Second record of Cryptotis parva (Soricidae: Insectivora) in New Mexico, with review of its status on the Llano Estacado. Southwestern Nat., 31:403-405.

PitTs, R. M., AND M. J. Smolen. 1988. Record of Cryptotis parva from Brown County, Texas. Texas J. Sci., 40:113-114.

YATES, T. L., and I. F. Greenbaum. 1982. Biochemical systematics of North American moles (Insectivoria: Talpidae). J. Mamm., 63:368-374.

\section{Chiroptera}

ARroyo-C., J., R. R. Hollander, AND J. K. JoneS, JR. 1987. Choeronycteris mexicana. Mamm. Species, 291:1-5.

BAKER, R. J., J. C. PATton, H. H. Genoways, AND J. W. Bickham. 1988. Genic studies of Lasiurus (Chiroptera: Vespertilionidae). Occas. Papers Mus., Texas Tech Univ., 117:1-15.

BICKHAM, J. W. 1987. Chromosomal variation among seven species of lasiurine bats (Chiroptera: Vespertilionidae). J. Mamm., 68:837-842.

BURNETT, C. D. 1983. Geographic and secondary sexual variation in the morphology of Eptesicus fuscus. Ann. Carnegie Mus., 52:139-162.

Chapman, S. S., AND B. R. Chapman. 1990. Bats from the coastal region of southern Texas. Texas J. Sci., 42:13-22.

Dalquest, W. W., AND F. B. Stangl, JR. 1984. The taxonomic status of Myotis magnamolaris Choate and Hall. J. Mamm., 65:485-486.

Fitch, J. H., K. A. Shump, JR., AND A. U. Shump. 1981. Myotis velifer. Mamm. Species, 149:1-5.

FRAZE, R. K., AND K. T. WILKINS. 1990. Patterns of use of man-made roosts by Tadarida brasiliensis mexicana in Texas. Southwestern Nat., 35:261-267. 
FreEMAN, P. W. 1981. Correspondence of food habits and morphology in insectivorous bats. J. Mamm., 62:166-173.

FujITA, M. S., AND T. H. KUNZ. 1984. Pipistrellus subflavus. Mamm. Species, 228:1-6.

GELFAND, D. L., AND G. F. MCCRACKEN. 1986. Individual variation in the isolation calls of Mexican free-tailed bat pups (Tadarida brasiliensis mexicana). Anim. Behav., 34: 1078-1086.

Geluso, K. N., J. S. AltenBaCh, AND D. E. WILson. 1981. Organochlorine residues in young Mexican free-tailed bats from several roosts. Amer. Midland Nat., 105:249-257.

GENOWAYS, H. H., AND R. J. BAKER. 1988. Lasiurus blossevillii (Chiroptera: Vespertilionidae) in Texas. Texas J. Sci., 40:111-113.

GLASS, B. P. 1982. Seasonal movements of Mexican freetail bats Tadarida brasiliensis mexicana banded in the Great Plains. Southwestern Nat., 27:127-133.

Gustin, M. K. 1984. Scent recognition between mother and young Tadarida brasiliensis mexicana. Bat Res. News, 25:44.

Gustin, M. K., AND G. F. MCCRACKEN. 1987. Scent recognition between females and pups in the bat Tadarida brasiliensis mexicana. Anim. Behav., 35:13-19.

Hermanson, J. W., AND T. J. O’Shea. 1983. Antrozous pallidus. Mamm. Species, 213:1-8.

HOLLANDER, R. R., AND J. K. JONES, JR. 1987. A record of the western small-footed myotis, Myotis ciliolabrum, from the Texas Panhandle. Texas J. Sci., 39:198.

JaCKson, J. A., B. J. SChARdien, C. D. CoOley, AND B. E. Rowe. 1982. Cave myotis roosting in barn swallow nests. Southwestern Nat., 27:462-463.

JoNES, C., AND R. W. MANNING. 1989. Myotis austroriparius. Mamm. Species, 332:1-3.

JONES, J. K., JR., AND R. W. MANNING. 1990. Additional comments on big brown bats (Eptesicus fuscus) from northwestern Texas. Southwestern Nat., 35:342-343.

Jones, J. K., JR., R. R. Hollander, AND R. W. MANning. 1987. The fringed myotis, Myotis thysanodes, in west-central Texas. Southwestern Nat., 32:149.

Kumiral, A., AND J. K. JoNes, JR. 1990. Nyctinomops femorosaccus. Mamm. Species, 349:1 -5.

KUNZ, T. H. 1982. Lasionycteris noctivagans. Mamm. Species, 172:1-5.

KunZ, T. H., AND R. A. MARTIN. 1982. Plecotus townsendii. Mamm. Species, 175:1-6.

KURTA, A., AND R. H. BAKER. 1990. Eptesicus fuscus. Mamm. Species, 356:1-10.

LEE, T. E. JR., 1987. Distributional record of Lasiurus seminolus (Chiroptera: Vespertilionidae). Texas J. Sci., 39:193.

MANNING, R. W., J. K. JONES, JR., AND C. JONES. 1989. Comments on distribution and variation in the big brown bat, Eptesicus fuscus, in Texas. Texas J. Sci., 41:95-101.

Manning, R. W., C. Jones, J. K. Jones, JR., ANd R. R. Hollander. 1988. Subspecific status of the pallid bat, Antrozous pallidus, in the Texas Panhandle and adjacent areas. Occas. Papers Mus., Texas Tech Univ., 118:1-5.

MANNing, R. W., J. K. Jones, JR., R. R. Hollander, AND C. Jones. 1987. Notes on distribution and natural history of some bats on the Edwards Plateau and in adjacent areas of Texas. Texas J. Sci., 39:279-285.

Martin, C. O., AND D. J. SChmidly. 1982. Taxonomic review of the pallid bat, Antrozous pallidus (Le Conte). Spec. Publ. Mus., Texas Tech Univ., 18:1-48.

MCCRACKEN, G. F. 1984. Communal nursing in Mexican free-tailed bat maternity colonies. Science, 223:1090-1091.

MCCRACKen, G. F., AND M. K. GUSTIN. 1987. Batmom's daily nightmare. Nat. Hist., 96:66-72.

MILNER, J., C. JONES, AND J. K. JONES, JR. 1990. Nyctinomops macrotis. Mamm. Species, 351:1-4.

OWEn, R. D., R. K. ChEsSER, AND D. C. CARTER. 1990. The systematic status of Tadarida brasiliensis cynocephala and Antillean members of the Tadarida brasiliensis group, with comments on the generic name Rhizomops Legendre. Occas. Papers Mus., Texas Tech Univ., 133:1-18. 
PITTS, R. M., AND J. J. SChARNINGHAUSEN. 1986. Use of cliff swallow and barn swallow nests by cave bat, Myotis velifer, and the free-tailed bat, Tadarida brasiliensis. Texas J. Sci., 38:265-266.

SCARBRough, D. L. 1989. Big free-tailed bat, Tadarida macrotis (Gray, 1839), from Brazos County, Texas. Texas J. Sci., 41:109.

SHUMP, K. A., JR., AND A. U. ShUMP. 1982a. Lasiurus borealis. Mamm. Species, 183:1-6. 1982b. Lasiurus cinereus. Mamm. Species, 185:1-5.

SPENCER, S. G., P. C. Choucair, AND B. R. Chapman. 1988. Northward expansion of the southern yellow bat, Lasiurus ega, in Texas. Southwestern Nat., 33:493.

TUTTLE, M. D. 1989. Texas bats: a resource in peril. Texas Parks and Wildlife, 47(4):2-7.

WARNER, R. M., AND N. J. CZAPLEWSKI. 1984. Myotis volans. Mamm. Species, 224:1-4.

WILKINS, K. T. 1987. Lasiurus seminolus. Mamm. Species, 280:1-5. 1989. Tadarida brasiliensis. Mamm. Species, 331:1-10.

ZEHNER, W. 1985. First record of Pipistrellus subflavus (Chiroptera: Vespertilionidae) on Padre Island, Texas. Southwestern Nat., 30:306-307.

\section{Xenarthra (Edentata)}

MCBEE, K., AND R. J. BAKER. 1982. Dasypus novemcinctus. Mamm. Species, 162:1-9.

MCDONOUGH, C., AND W. J. HAMILTON, III, 1989. Behavior and ecology of nine-banded armadillos in South Texas. Welder Wildlife Found. Biennial Rept., p. 16.

MONTGOMERY, G. G. (ed.). 1985. The evolution and ecology of armadillos, sloths, and vermalinguas, Smithsonian Inst. Press, Washington, 451 pp.

SMITH, L. L., AND R. W. Doughty. 1984. The amazing armadillo .... Univ. Texas Press, Austin, xi $+134 \mathrm{pp}$.

\section{LAGOMORPHA}

Chapman, J. A., And G. A. Feldhamer. 1981. Sylvilagus aquaticus. Mamm. Species, 151:1-4.

DALQUEST, W. W., F. B. STANGL, JR., AND J. V. GRIMES. 1989. The third lower molar of the cottontail, genus Sylvilagus, and its value in the discrimination of three species. Amer. Midland Nat., 121:293-301.

Henke, S. E., AND S. Demarais. 1990. Capturing jackrabbits by drive corral on grasslands in West Texas. Wildlife Soc. Bull., 18:31-33.

HULBERT, R. C., JR. 1984. Latest Pleistocene and Holocene leporid faunas from Texas: their composition, distribution and climatic implications. Southwestern Nat., 29:197-210.

RogowITZ, G. L., AND M. L. WOLFE. 1985. The bioenergetics of white-tailed jackrabbits. Welder Wildlife Found. Biennial Rept., p. 14.

1987. Thermorefugation in the white-tailed jackrabbit. Welder Wildlife Found. Biennial Rept., p. 10.

SCRIBNER, K. T., AND L. J. KRYSL. 1982. Summer foods of the Audubon's cottontail (Sylvilagus auduboni: Leporidae) on Texas Panhandle playa basins. Southwestern Nat., 27:460-463.

SCRIBNER, K. T., AND R. J. WARREN. 1981a. Annual fluctuations in playa lake cottontail rabbit populations. Research Highlights-1981, Noxious Brush and Weed Control, Texas Tech Univ., 12:46-47.

1981b. Morphologic and electrophoretic characteristics of two West Texas cottontail rabbit species. Research Highlights-1981, Noxious Brush and Weed Control, Texas Tech Univ., 12:47-48.

1982. Population ecology and genetics of two sympatric cottontail species in the Texas Panhandle. Caesar Kleberg Found. Wildlife Conserv., Ann. Rept., Texas Tech Univ., 3:5-6. 
1983. Population ecology and genetics of two sympatric cottontail species in the the Texas Panhandle. Caesar Kleberg Found. Wildlife Conserv., Ann. Rept., Texas Tech Univ., 4:22-23.

1986. Electrophoretic and morphologic comparisons of Sylvilagus floridanus and $S$. audubonii in Texas. Southwestern Nat., 31:65-71.

1990. Seasonal demography and movements of cottontail rabbits on isolated playa basins. J. Wildlife Manag., 54:403-409.

SCRIBNER, D. T., F. K. ChESSER, AND R. J. WARREN. 1982. Spatial and temporal genetic variability of the eastern cottontail on West Texas playa basins. Research Highlights-1982, Noxious Brush and Weed Control, Texas Tech Univ., 13:51.

1983. Spatial and temporal genetic variability of the eastern cottontail on West Texas playa basins. J. Mamm., 64:287-294.

\section{RODENTIA}

Arnold, M. L., L. W. Robiins, R. K. Chesser, And J. C. PATton. 1983. Phylogenetic relationships among six species of Reithrodontomys. J. Mamm., 64:128-132.

Austin, T. A., AND J. A. KitChENS. 1986. Expansion of Baiomys taylori into Hardeman County, Texas. Southwestern Nat., 31:547-548.

Baccus, J. T., AND J. K. HoRTON. 1984. Habitat utilization by Peromyscus pectoralis in central Texas. Pp. 7-26, in Festschrift for Walter W. Dalquest in honor of his sixty-sixth birthday (N. V. Horner, ed.), Dept. Biology, Midwestern State Univ., Wichita Falls, Texas, xx $+163 \mathrm{pp}$.

BAKER, R. H. 1989. The Texas beaver: described from Colorado County. Nesbitt Mem. Lib. J., I:24-27.

BAKER, R. J., AND H. A. WICHMAN. 1990. Retrotransposon mys is concentrated on the sex chromosomes: implications for copy number containment. Evolution, 44:283-288.

BAKER, R. J., R. K. ChESSER, B. F. KoOP, AND R. A. HoYT. 1983. Adaptive nature of chromosomal rearrangement: differential fitness in pocket gophers. Genetica, 61:161-164.

Baker, R. J., L. W. Robbins, F. B. Stangl, JR., AND E. C. BiRney. 1983. Chromosomal evidence for a major subdivision in Peromyscus leucopus. J. Mamm., 64:356-359.

Baker, R. J., S. K. Davis, R. D. Bradley, M. J. Hamilton, and R. A. VAN Den Bussche. 1989. Ribosomal-DNA, mitochondrial-DNA, chromosomal, and allozymic studies on a contact zone in the pocket gopher, Geomys. Evolution, 43:63-75.

Baumgardner, G. D. 1989. Refinement of the type locality and distribution of Dipodomys compactus sennetti (J. A. Allen, 1891). Texas J. Sci., 41:103-104.

BAUMGaRDNER, G. D., AND D. J. SCHMidLY. 1981. Systematics of the southern races of two species of kangaroo rats (Dipodomys compactus and D. ordii). Occas. Papers Mus., Texas Tech Univ., 73:1-27.

1985. Microhabitat relationships of kangaroo rats (Dipodomys compactus and D. ordii) in southern Texas. Southwestern Nat., 30:315-317.

BEST, T. L. 1987. Sexual dimorphism and morphometric variation in the Texas kangaroo rat (Dipodomys elator Merriam 1894). Southwestern Nat., 32:53-59.

1988. Dipodomys spectabilis. Mamm. Species, 311:1-10.

Best, T. L., C. L. Lewis, K. CAESAR, AND A. S. Titus. 1990. Ammospermophilus interpres. Mamm. Species, 365:1-6.

Bıскнам, J. W. 1983. Sibling species. Pp. 96-106, in Genetics and conservation ... (C. M. Schonewald-Cox, S. M. Chambers, B. MacBryde, and W. L. Thomas, eds.), Benjamin/Cummings Publ. Co., Inc., London. 722 pp. 
1990. Flow cytometry as a technique to monitor the effects of environmental genotoxins on wildlife populations. Pp. 97-108, in In situ evaluations of biological hazards of environmental pollutants (S. S. Sandhu et al., eds.), Plenum Press, New York, 277 pp.

Bohlin, R. G., AND E. G. Zimmerman. 1982. Genic differentiation in two chromosome races of the Geomys bursarius complex. J. Mamm., 63:218-228.

BRAUN, J. K. 1988. Systematics and biogeography of the southern flying squirrel, Glaucomys volans. J. Mamm., 69:422-426.

BRAUN, J. K., AND M. A. MARES. 1989. Neotoma micropus. Mamm. Species, 330:1-9.

BURTON, D. W., AND J. W. BICKHAM. 1989. Heterochromatin variation and DNA content conservatism in Geomys attwateri and G. breviceps (Rodentia: Geomyidae). J. Mamm., 70:580591.

Calhoun, S. W., M. D. Engstrom, and I. F. Greenbaum. 1989. Biochemical variation in pygmy mice (Baiomys). J. Mamm., 70:374-381.

CAmeron, G. N., AND W. B. KinCAID. 1982. Species removal effects on movements of Sigmodon hispidus and Reithrodontomys fulvescens. Amer. Midland Nat., 108:60-67.

Cameron, G. N., AND P. A. MCClure. 1990. Geographic variation in life history traits of the hispid cotton rat (Sigmodon hispidus). Pp. 33-64, in Evolution of life histories of mammals ... (M. S. Boyce, ed.), Yale Univ. Press, New Haven, Connecticut, xvi + 373 pp.

Cameron, G. N., and S. R. Spencer. 1981. Sigmodon hispidus. Mamm. Species, 158:1-9.

- 1983 . Field growth rates and dynamics of body mass for rodents on the Texas coastal prairie. J. Mamm., 64:656-665.

1985. Assessment of space-use patterns in the hispid cotton rat (Sigmodon hispidus). Oecologia, 68:133-139.

Cameron, G. N., S. R. Spencer, B. D. Eshelman, L. R. Williams, and M. J. Gregory. 1988. Activity and burrow structure of Attwater's pocket gopher (Geomys attwateri). J. Mamm., 69:667-677.

CARLeton, M. D. 1989. Systematics and evolution. Pp. 7-141, in Advances in the study of Peromyscus (Rodentia) (G. L. Kirkland, Jr., and J. N. Layne, eds.), Texas Tech Univ. Press, Lubbock, $367 \mathrm{pp}$.

CArter, D. C., W. D. Webster, J. K. Jones, JR., C. Jones, and R. D. SuttKus. 1985. Dipodomys elator. Mamm. Species, 232:1-3.

ChOATE, L. L., AND J. K. JONES, JR. 1989. Notes on reproduction in the hispid pocket mouse, Chaetodipus hispidus, in Texas. Texas J. Sci., 41:432-433.

ChOATE, L. L., J. K. Jones, JR., R. W. MANNing, AND C. JonES. 1990. Westward ho: continued dispersal of the pygmy mouse, Baiomys taylori, on the Llano Estacado and in adjacent areas of Texas. Occas. Papers Mus., Texas Tech Univ., 134:1-8.

Cleveland, A. G. 1986. First record of Baiomys taylori north of the Red River. Southwestern Nat., 31:547.

Cornely, J. E., D. J. Schmidly, H. H. Genoways, and R. J. Baker. 1981. Mice of the genus Peromyscus in Guadalupe Mountains National Park, Texas. Occas. Papers Mus., Texas Tech Univ., 74: 1-35.

COTHRAN, E. G. 1983. Morphologic relationships of the hybridizing ground squirrels Spermophilus mexicanus and S. tridecemlineatus. J. Mamm., 64:591-602.

COTHRAN, E. G., AND R. L. HONEYCUTT. 1984. Chromosomal differentiation of hybridizing ground squirrels (Spermophilus mexicanus and S. tridecemlineatus). J. Mamm., 65:118-122.

Cothran, E. G., AND E. G. Zimmerman. 1985. Electrophoretic analysis of the contact zone between Geomys breviceps and Geomys bursarius. J. Mamm., 66:489-497. 
Dalquest, W. W., AND R. M. CARPENTER. 1986. Dental characters of some fossil and Recent kangaroo rats, with description of a new species of Pleistocene Dipodomys. Texas J. Sci., 38:251-263.

DALQueST, W. W., AND F. B. STANGL, JR. 1983. Identification of seven species of Peromyscus from Trans-Pecos Texas by characters of the lower jaws. Occas. Papers Mus., Texas Tech Univ., 90:1-12.

DAVIDOW-HENRY, B. R., AND J. K. JONES, JR. 1988. Notes on reproduction and postjuvenile molt in two genera of pocket gophers, Cratogeomys and Thomomys, in Texas. Texas J. Sci., 40:259-261.

DaVidow-HenRY, B. R., J. K. JoNeS, JR., AND R. R. Hollander. 1989. Cratogeomys castanops. Mamm. Species, 338:1-6.

DERTING, T. L., AND P. A. MCCLURE. 1989. Intraspecific variation in metabolic rate and its relationship with productivity in the cotton rat, Sigmodon hispidus. J. Mamm., 70:520-531.

DOERR, S. M., AND F. W. JUDD. 1984. Reproductive ecology of the pocket gopher, Geomys personatus, in South Texas. Texas J. Sci., 36:129-138.

DOWLER, R. C. 1989. Cytogenetic studies of three chromosomal races of pocket gophers (Geomys bursarius complex) at hybrid zones. J. Mamm., 70:253-266.

ELDER, F. F. B., AND M. R. LEE. 1985. The chromosomes of Sigmodon ochrognathus and S. fulviventer suggest a realignment of Sigmodon species group. J. Mamm., 66:511-518.

ENGSTROM, M. D., AND J. W. Bickham. 1982. Chromosome banding and phylogenetics of the golden mouse, Ochrotomys nuttalli. Genetica, 59:119-126.

ENGSTROM, M. D., D. J. SCHMIDLY, AND P. K. FoX. 1982. Nongeographic variation and discrimination of species within the Peromyscus leucopus species group (Mammalia: Cricetinae) in eastern Texas. Texas J. Sci., 34:149-162.

Engstrom, M. D., R. C. Dowler, D. S. Rogers, D. J. SChmidly, AND J. W. BiCKham. 1981. Chromosomal variation within four species of harvest mice (Reithrodontomys). J. Mamm., 62:159-164.

Eshelman, B. D., AND G. N. CAMERon. 1987. Baiomys taylori. Mamm. Species, 285:1-7.

ETHEREDGE, D. R., M. D. ENGSTROM, AND R. C. STONE, JR. 1989. Habitat discrimination between sympatric populations of Peromyscus attwateri and Peromyscus pectoralis in westcentral Texas. J. Mamm., 70:300-307.

Feldman, J. F., AND C. J. PhILliPS. 1984. Comparative retinal pigment epithelium and photoreceptor ultrastructure in nocturnal and fossorial rodents: the eastern woodrat, Neotoma floridana, and the plains pocket gopher, Geomys bursarius. J. Mamm., 65:231-245.

Fuller, B., M. R. LeE, AND L. R. MAXsON. 1984. Albumin evolution in Peromyscus and Sigmodon. J. Mamm., 65:466-473.

Garrison, T. E., AND T. L. Best. 1990. Dipodomys ordii. Mamm. Species, 353:1-10.

GoETZE, J. R., AND F. B. STANGL, JR. 1989. Spring molt in the Mexican ground squirrel, Spermophilus mexicanus (Rodentia: Sciuridae). Texas J. Sci., 41:430-431.

Gregory, M. J., AND G. N. CAMERON. 1988. Examination of socially induced dispersal in Sigmodon hispidus. J. Mamm., 69:251-260.

1989. Scent communication and its association with dominance behavior in the hispid cotton rat (Sigmodon hispidus). J. Mamm., 70:10-17.

Gregory, M. J., G. N. CAmeron, L. M. Combs, AND L. R. Williams. 1987. Agonistic behavior in Attwater's pocket gopher, Geomys attwateri. Southwestern Nat., 32:143-146.

GuETzow, D. D., ANDF. W. JUDD. 1981. Postnatal growth and development in a subtropical population of Peromyscus leucopus texanus. Southwestern Nat., 26:183-191.

GUTHERY, F. S., AND N. H. HERBERT. 1983. Attributes of capture-recapture data for Sigmodon hispidus. Southwestern Nat., 28:108-111. 
Hamilton, M. J., R. K. ChesSER, AND T. L. Best. 1987. Genetic variation in the Texas kangaroo rat, Dipodomys elator Merriam. J. Mamm., 68:775-781.

HAMILTON, M. J., R. L. HONEYCUTT, AND R. J. BAKER. 1990. Intragenomic movement, sequency amplification and concerted evolution in statelite DNA in harvest mice, Reithrodontomys: evidence from in situ hybridization. Chromosoma, 99:321-329.

HiCKMAN, G. C. 1984. Behavior of North American geomyids during surface movement and construction of earth mounds. Spec. Publ. Mus., Texas Tech Univ., 22:165-186.

Hoffmeister, D. H. 1981. Peromyscus truei. Mamm. Species, 161:1-5.

HOLLANDER, R. R. 1990. Biosystematics of the yellow-faced pocket gopher, Cratogeomys castanops (Rodentia: Geomyidae) in the United States. Spec. Publ. Mus., Texas Tech Univ., 33:1-62.

HollaNDER, R. R., B. N. HICKS, AND J. F. SCUDDAY. 1990. Distributional records of the yellownosed cotton rat, Sigmodon ochrognathus Bailey, in Texas. Texas J. Sci., 42:101-102.

HONEYCUTT, R. L., AND S. L. WILliams. 1982. Genic differentiation in pocket gophers of the genus Pappogeomys, with comments on intergeneric relationships in the subfamily Geomyinae. J. Mamm., 63:208-217.

Hood, C. S., L. W. Robbins, R. J. BaKeR, and H. S. Shellhammer. 1984. Chromosomal studies and evolutionary relationships of an endangered species, Reithrodontomys raviventris. J. Mamm., 65:655-667.

HUMPHREY, S. R., AND H. W. SETZER. 1989. Geographic variation and taxonomic revision of rice rats (Oryzomys palustris and $O$. argentatus) of the United States. J. Mamm., 70:557-570.

HUNTLEY, J. C. 1983. Squirrel den tree management reducing incompatibility with timer production in upland hardwoods. Proc. Second Biennial Southern Silvicultural Res. Conf., USDA For. Serv., Gen. Tech. Rept. SE-24, pp. 488-495.

1986. Wilderness areas: impact on gray and fox squirrels. Wilderness and natural areas in the Eastern United States ... (D. L. Kulhavy and R. N. Conner, eds.), Stephen F. Austin State University, Nacogdoches, Texas, pp. 54-61.

Janecek, L. L. 1990. Genic variation in the Peromyscus truei group (Rodentia: Cricetidae). J. Mamm., 71:301-308.

JOHNSON, K. 1981. Social organization in a colony of rock squirrels (Spermophilus variegatus, Sciuridae). Southwestern Nat., 26:237-242.

Jones, C., M. A. Bogan, AND L. M. MounT. 1988. Status of the Texas kangaroo rat (Dipodomys elator). Texas J. Sci., 40:249-258.

JONES, J. K., JR., AND R. W. MANNING. 1989. The northern pygmy mouse, Baiomys taylori, on the Texas Llano Estacado. Texas J. Sci., 41:110.

JUDD, F. W., AND G. CARPENTER. 1984. Annual variation in the lipid cycle of a subtropical population of Peromyscus leucopus. Pp. 77-86, in Festschrift for Walter W. Dalquest in honor of his sixty-sixth birthday (N. V. Horner, ed.), Dept. Biology, Midwestern State Univ., Wichita Falls, Texas, $x x+163 \mathrm{pp}$.

JUDD, F. W., G. CARPENTER, AND M. WAGNER. 1984. Variation in reproduction of a subtropical population of Peromyscus leucopus. Spec. Publ. Mus., Texas Tech Univ., 22:125-135.

KARGES, J. P., AND O. S. PARKER. 1984. Distribution of the Mexican spiny pocket mouse (Liomys irroratus: Heteromyidae) in Texas. Southwestern Nat., 29:229-230.

KilPatrick, C. W. 1984. Molecular evolution of the Texas mouse, Peromyscus attwateri. Pp. 87 96, in Festschrift for Walter W. Dalquest in honor of his sixty-six th birthday (N. V. Horner, ed.), Dept. Biology, Midwestern State Univ., Wichita Falls, Texas, $x x+163$ pp.

KINCAID, W. B., AND G. N. CAMERON. 1982a. Effects of species removal on resource utilization in a Texas rodent community. J. Mamm., 63:229-235. 
1982b. Dietary variation in three sympatric rodents on the Texas coastal prairie. J. Mamm., 63:668-672.

1985. Interactions of cotton rats with a patchy environment: dietary responses and habitat selection. Ecology, 66:1769-1783.

KinCaid, W. B., G. N. Cameron, AND B. A. CARnes. 1983. Patterns of habitat utilization in sympatric rodents on the Texas coastal prairie. Ecology, 64:1471-1480.

KOOP, B. F., R. J. BAKER, AND T. J. MASCARELLO. 1985. Cladistical analysis of chromosomal evolution within the genus Neotoma. Occas. Papers Mus., Texas Tech Univ., 96:1-9.

KOOP, B. F., R. J. BAKER, M. W. HAIDUK, AND M. D. ENGSTROM. 1984. Cladistical analysis of primitive G-band sequences for the karyotype of the ancestor of the Cricetidae complex of rodents. Genetics, 64:199-208.

LACKey, J. A., D. G. HuCKaby, AND B. G. ORMiston. 1985. Peromyscus leucopus. Mamm. Species, 247:1-10.

LEE, H. K., AND R. J. BAKER. 1987. Cladistical analysis of chromosomal evolution in pocket gophers of the Cratogeomys castanops complex (Rodentia: Geomyidae). Occas. Papers Mus., Texas Tech Univ., 114:1-15.

LEE, T. E., JR., AND L. A. RuEDAS. 1989. Distributional records of the northern rice rat, Oryzomy's palustris (Rodentia: Cricetidae). Texas J. Sci., 41:336-337.

LENINGTON, S., P. FRANKS, AND J. WILliamS. 1988. Distribution of $t$-haplotypes in natural populations of wild house mice. J. Mamm., 69:489-499.

LEVICK, J. P. 1982. Maternal response to neonate vocalizations in Ord's kangaroo rat (Dipodomys ordii). Southwestern Nat., 27:122-123.

Loven, J. E. 1985. Reported beaver damage and control methods used in Texas. Proc. Great Plains Wildlife Damage Control Workshop, 7:145-151.

LOUGHRY, W. J. 1989. Discrimination of snakes by two populations of black-tailed prairie dogs. J. Mamm., 70:627-630.

MACEDO, R. H., AND M. A. MARES. 1988. Neotoma albigula. Mamm. Species, 310:1-7.

MANNING, R. W., AND J. K. JONES, JR. 1988. A specimen of the prairie vole, Microtus ochrogaster, from the northern Texas Panhandle. Texas J. Sci., 40:463-464.

MARTIN, R. E. 1984. Analysis of behavioral patterns in populations of silky pocket mice, genus Perognathus (Rodentia: Heteromyidae). Spec. Publ. Mus., Texas Tech Univ., 22:187-213.

Matocha, K. G. 1982. The reproductive cycle of the Mexican ground squirrel (Spermophilus mexicanus) in southern Texas. P. vii, in South Texas fauna-a symposium honoring Dr. Allan H. Chaney (B. R. Chapman and J. W. Tunnell, Jr., eds.), Caesar Kleberg Wildlife Res. Inst., Kingsville, Texas, viii +97 pp.

1984. Variation of the trill calls of three species of Spermophilus. Spec. Publ. Mus., Texas Tech Univ., 22:215-223.

MCALPINE, S. 1988. Preliminary results of biomass partitioning in three Chihuahuan Desert rodent communities. Contrib. Papers Second Symp. Resources Chihuahuan Desert region ..., Chihuahuan Desert Res. Inst., Alpine, Texas, 15:1-7 (processed).

MCAllister, C. T. 1989. The Texas mouse, Peromyscus attwateri (Rodentia: Cricetidae), in Hood and Johnson counties, Texas. Texas J. Sci., 41:329-330.

MCBeE, K., AND J. W. Bickham. 1988. Petrochemical-related DNA damage in wild rodents detected by flow cytometry. Bull. Environm. Contam. Toxicol., 40:343-349 (processed).

McBee, K., J. W. Bickham, K. W. Brown, AND K. C. Donnelly. 1987. Chromosomal abertations in native small mammals (Peromyscus leucopus and Sigmodon hispidus) at a petrochemical waste disposal site: I. Standard karyology. Arch. Environ. Contam. Toxicol., 16:681-688. 
McCullough, D. A., AND R. K. CHESSER. 1987. Genetic variation among populations of the Mexican prairie dog. J. Mamm., 68:555-560.

McCullough, D. A., R. K. ChesSER, AND R. D. OWEN. 1987. Immunological systematics of prairie dogs. J. Mamm., 68:561-568.

Mullican, T. R., AND J. T. BAcCuS. 1990. Horizontal and vertical movements of the whiteankled mouse (Peromyscus pectoralis) in central Texas. J. Mamm., 71:378-381.

MURIE, J. O., AND G. R. MiChENER (eds.). 1984. The biology of ground-dwelling squirrels. Univ. Nebraska Press, Lincoln, xvi $+459 \mathrm{pp}$.

NELSON, K., R. J. BAKER, AND R. L. HoNEYCUTT. 1987. Mitochrondrial DNA and protein differentiation between hybridizing cytotypes of the white-footed mouse, Peromyscus leucopus. Evolution, 41:864-872.

Nelson, K., R. J. Baker, H. S. Shellhammer, AND R. K. Chesser. 1984. Test of alternative hypothesis concerning the origin of Reithrodontomys raviventris: genetic analysis. J. Mamm., 65:668-673.

OAKS, E. C., P. J. Young, G. L. Kirkland, JR., AND D. F. SChmidT. 1987. Spermophilus variegatus. Mamm. Species, 272:1-8.

OWEN, J. G. 1989. Population and geographic variation of Peromyscus leucopus in relation to climatic factors. J. Mamm., 70:98-109.

OWEN, R. D., AND K. MCBEE. 1990. Analysis of asymmetry and morphometric variation in natural populations of chromosome-damaged mice. Texas J. Sci., 42:319-332.

PARKER, S. 1982. Geographic distribution and taxonomic status of rice rats (genus Oryzomys) in Texas. P. viii, in South Texas fauna-a symposium honoring Dr. Allan H. Chaney (B. R. Chapman and J. W. Tunnell, Jr., eds.), Caesar Kleberg Wildlife Res. Inst., Kingsville, Texas, viii $+97 \mathrm{pp}$.

Patton, J. C., R. J. BAKER, AND J. C. Avise. 1981. Phenetic and cladistic analysis of biochemical evolution in peromyscine rodents. Pp. 288-308, in Mammalian population genetics (M. H. Smith and J. Joule, eds.), Univ. Georgia Press, Athens, xii + 380 pp. (processed).

Paulson, D. D. 1988. Chaetodipus hispidus. Mamm. Species, 320:1-4.

PITTS, R. M. 1978. Carnivorous behavior in pygmy mice (Baiomys taylori). Bios., 49:107-108.

PITTS, R. M., AND H. W. GARNER. 1988. An observation of allomaternal nursing among captive Baiomy's taylori. Southwestern Nat., 33:496-497.

PitTs, R. M., AND G. F. KING. 1988. A new locality of record for the eastern harvest mouse (Reithrodontomy's humulis) in northeastern Texas. Texas J. Sci., 40:461-462.

PITTS, R. M., AND M. J. SMOLEN. 1988. Records extending the breeding season of the whitethroated woodrat, Neotoma albigula, in southwestern Texas. Texas J. Sci., 40:462-463. 1989. Status of Baiomys taylori in Texas, with new localities of record in the southern part of the state. Texas J. Sci., 41:85-88.

PUTERA, J. A., AND W. E. GRANT. 1985. Influence of behavioral interactions on spacial segregation of sympatric Sigmodon, Baiomys, and Reithrodontomys populations. J. Mamm., 66:380-384.

QumsiYeh, M. B., C. SANChez-H, S. K. Davis, J. C. Patton, AND R. J. BaKeR. 1988. Chromosomal evolution in Geomys as revealed by G-and C-band analysis. Southwestern Nat., 33:1-13.

REED, K. M., AND J. R. ChOATE. 1986. Geographic variation in the plains pocket mouse (Perognathus flavescens) on the Great Plains. Texas J. Sci., 38:227-240.

ROGERS, D. S. 1990. Genic evolution, historical biogeography, and systematic relationships among spiny pocket mice (subfamily Heteromyinae). J. Mamm., 71:668-685. 
ROGERS, D. S., AND D. J. SCHMIDLY. 1981. Geographic variation in the white-throated woodrat (Neotoma albigula) from New Mexico, Texas, and northern Mexico. Southwestern Nat., 26:167-181.

RobBINS, L. W. 1981. Sex chromosome polymorphisms in Reithrodontomys montanus (Rodentia: Cricetidae). Southwestern Nat., 26:201-202.

ROBBINS, L. W., AND R. J. BAKER. 1981. An assessment of the nature of chromosomal rearrangements in 18 species of Peromyscus (Rodentia: Cricetidae). Cytogenet. Cell Genet., 31:194-202.

Robbins, L. W., M. H. Smith, M. C. Wooten, AND R. K. SElander. 1985. Biochemical polymorphism and its relationship to chromosomal and morphological variation in Peromyscus leucopus and Peromyscus gossypinus. J. Mamm., 66:498-510.

RYLANDER, M. K. 1981. Brain volume and cell density in two kangaroo rats, Dipodomys merriami and D. ordii. Texas J. Sci., 33:39-41.

Segers, J. C., AND B. R. Chapman. 1984. Ecology of the spotted ground squirrel, Spermophilus spilosoma (Merriam), on Padre Island, Texas. Spec. Publ. Mus., Texas Tech Univ., 22:105-112.

ShIPLEY, M. M., F. B. STANGL, JR., R. L. CATE, AND C. S. Hood. 1990. Immunoelectrophoretic relationships among four species of wooodrats (Cricetidae: Neotoma). Southwestern Nat., 35:173-176.

SMITH, J. 1982. Home range activity and habitat preference of Peromyscus leucopus. Pp. 1-18, in South Texas fauna-a symposium honoring Dr. Allan H. Chaney (B. R. Chapman and J. W. Tunnell, Jr., eds.), Caesar Kleberg Wildlife Res. Inst., Kingsville, Texas, viii + 97 pp.

SMrTh, S. A. 1990. Cytosystematic evidence against monophyly of the Peromyscus boy/ii species group (Rodentia: Cricetidae). J. Mamm., 71:654-667.

SMITH, T. S., S. A. SMITH, AND D. J. SChmidLY. Impact of fire ant (Solenopsis invicta) density on northern pygmy mice (Baiomys taylori). Southwestern Nat., 35:158-162.

SMOLEN, M. J. 1981. Microtus pinetorum. Mamm. Species, 147:1-7.

SPENCER, S. R., AND G. N. CAMERON. 1982. Reithrodontomys fulvescens. Mamm. Species, 174:1-7.

- 1983. Behavioral dominance and its relationship to habitat patch utilization by the hispid cotton rat (Sigmodon hispidus). Behav. Ecol. Sociobiol., 13:27-36.

1985. Response of the fulvous harvest mouse (Reithrodontomys fulvescens) to artificial habitat patchiness. Amer. Midland Nat., 114:135-144.

1988. Home range of the fulvous harvest mouse (Reithrodontomys fulvescens) on the Texas coastal prairie. Amer. Midland Nat., 120:250-257.

SPEnCER, S. R., G. N. CAMERON, AND W. B. KinCAID. 1982. Multiple captures of the fulvous harvest mouse (Reithrodontomys fulvescens). Amer. Midland Nat., 107:384-385.

SPEnCER, S. R., G. N. Cameron, B. D. Eshelman, L. C. CoOPER, AND L. R. Williams. 1985. Influence of pocket gopher mounds on a Texas coastal prairie. Oecologia, 66:111-115.

Stalling, D. T. 1990. Microtus ochrogaster. Mamm. Species, 355:I-9.

StANGL, F. B., JR. 1986. Aspects of a contact zone between two chromosomal races of Peromyscus leucopus (Rodentia: Cricetidae). J. Mamm., 67:465-473.

StANGL, F. B., JR., AND R. J. BAKer. 1984. A chromosomal subdivision in Peromyscus leucopus: implications for the subspecies concept as applied to mammals. Pp. 139-145, in Festschrift for Walter W. Dalquest in honor of his sixty-sixth birthday (N. V. Horner, ed.), Dept. Biology, Midwestern State Univ., Wichita Falls, Texas, $x x+163$ pp.

StanGl, F. B., JR., AND W. W. Dalquest. 1990. Discrimination of two species of cotton rats (Sigmodon) using characters of the first upper molar. Texas J. Sci., 42:333-338. 
StANGl, F. B., JR., AND J. V. Grimes. 1987. Phylogenetic implications of comparative pelage morphology in Aplodontidae and the Nearctic Sciuridae, with observations on seasonal pelage variation. Occas. Papers Mus., Texas Tech Univ., 112:1-21.

- 1990. Supernumerary hind foot on a specimen of the Texas mouse, Peromyscus attwateri (Rodentia: Cricetidae). Southwestern Nat., 35:371-373.

STANGL, F. B., JR., AND S. KASPER. 1987. Evidence of communal nesting and winter-kill in a population of Baiomys taylori from north-central Texas. Texas J. Sci., 39:292-293.

STANGL, F. B., JR., E. BARBERIDES, ANDJ. K. SPEIGHTS. 1989. Chromosomal banding study of the hispid pocket mouse, Chaetodipus hispidus (Rodentia: Heteromyidae). Texas J. Sci., 41:71-76.

StANGL, F. B., JR., J. V. GrimES, AND J. R. GoETZE. 1986. Characterization of seasonal pelage extremes in Spermophilus mexicanus (Rodentia: Sciuridae). Texas J. Sci., 38:147-152.

StanGl, F. B., JR., W. E. HindS, AND F. K. PASSMANN. 1989. Asymmetrical incisor wear in three species of pocket gophers (Rodentia: Geomyidae). Prairie Nat., 21:169-173.

STANGL, F, B., JR., B. F. KoOP, AND C. S. HoOD. 1983. Occurrence of Baiomys taylori (Rodentia: Cricetidae) on the Texas High Plains. Occas. Papers Mus., Texas Tech Univ., 85:1-4.

STEIN, B. R. 1988. Morphology and allometry in several genera of semiaquatic rodents (Ondatra, Nectomys, and Oryzomys). J. Mamm., 69:500-511.

STRONG, P. I. V., AND J. A. BISSONETTE. 1988. Ecological implications of living in desert riparian habitats: beaver. Contrib. Papers Second Symp. Resources Chihuahuan Desert region ...., Chihuahuan Desert Res., Inst., Alpine, Texas, 17:1-7 (processed).

SUllivan, R. M., D. J. HAFNER, AND T. L. YATES. 1986. Genetics of a contact zone between three chromosomal forms of the grasshopper mouse (genus Onychomys): a reassessment. J. Mamm., 67:640-659.

TUCKER, P. K., AND D. J. SCHMIDLY. 1981. Studies of a contact zone among three chromosomal races of Geomys bursarius in East Texas. J. Mamm., 62:258-272.

TURNER, C. L., AND W. E. GRANT. 1987. Effect of removal of Sigmodon hispidus on microhabitat utilization by Baiomys taylori and Reithrodontomys fulvescens. J. Mamm., 68:80-85.

WADE, D. A., AND C. W. RAMSEY. 1986. Identifying and managing aquatic rodents in Texas: beaver, nutria and muskrats. Texas Agric. Ext. Serv., College Station, 46 pp.

WEBStER, W. D., AND J. K. JONES, JR. 1982. Reithrodontomys megalotis. Mamm. Species, 167:1-5. 1985. Nongeographic variation, reproduction, and demography in the Texas kangaroo rat, Dipodomys elator (Rodentia: Heteromyidae). Texas J. Sci., 37:51-61.

WILEY, R. W. 1984. Reproduction in the southern plains woodrat (Neotoma micropus) in western Texas. Spec. Publ. Mus., Texas Tech Univ., 22:137-164.

WILHELM, D. E., JR. 1982. Zoogeographic relationships of selected populations of Microtus mexicanus. Occas. Papers Mus., Texas Tech Univ., 75:1-30.

WILKINS, K. T. 1986. Reithrodontomys montanus. Mamm. Species, 257:1-5.

1990. Range extension and county records for two species of rodents in Texas. Texas J. Sci., 42:199-200.

WiLlging, B., AND R. SRAMEK. 1989. Urban beaver damage and control in Dallas-Fort Worth, Texas. Proc. Great Plains Wildlife Damage Control Workshop, 9:77-80 (processed).

Williams, L. R., AND G. N. CAMERON. 1984. Demography of dispersal in Attwater's pocket gopher (Geomys attwateri). J. Mamm., 65:67-75.

1985. Microgeographic variation in the demography of Attwater's pocket gopher and the relationship of demography to availability and utilization of resources. Welder Wildlife Found. Biennial Rept., p. 14.

1986a. Effects of removal of pocket gophers on a Texas coastal prairie. Amer. Midland Nat., 115:216-224. 
1986b. Food habits and dietary preferences of Attwater's pocket gopher, Geomys attwateri. J. Mamm., 67:489-496.

1990a. Dynamics of burrows of Attwater's pocket gopher (Geomys attwateri). J. Mamm., 71:433-438.

$1990 \mathrm{~b}$. Intraspecific response to variation in food resources by Attwater's pocket gopher. Ecology, 71:797-810.

Williams, L. R., G. N. Cameron, S. R. Spencer, B. D. Eshelman, and M. J. Gregory. 1986. Experimental analysis of the effects of pocket gopher mounds on Texas coastal prairie. J. Mamm., 67:672-679.

Williams, S. L. 1982. Geomys personatus. Mamm. Species, 170:1-5.

WOLFE, J. L. 1982. Oryzomys palustris. Mamm. Species, 176:1-5.

WRIGHT, M. 1982. Cycles and density of a Sigmodon hispidus population in South Texas. Pp. 1929, in South Texas fauna- a symposium honoring Dr. Allan H. Chaney (B. R. Chapman and J. W. Tunnell, Jr., eds.), Caesar Kleberg Wildlife Res. Inst., Kingsville, Texas, viii + $97 \mathrm{pp}$.

YounG, C. J., AND J. K. JONES, JR. 1982. Spermophilus mexicanus. Mamm. Species, 164:1-4.

Zimmerman, E. G. 1988. Temporal genetic variation in a population of the pocket gopher, Geomys bursarius. Genetica, 76:153-159.

ZIMMERMAN, E. G., AND N. A. GAYDEN. 1981. Analysis of genic heterogeneity among local populations of the pocket gopher, Geomys bursarius. Pp. 272-287, in Mammalian population genetics (M. H. Smith and J. Joule, eds.), Univ. Georgia Press, Athens, xii + 380 pp. (processed).

\section{Cetacea}

Barros, N. B., AND D. K. Odell. 1990. Food habits of bottlenose dolphins in the southeastern United States. Pp. 309-328, in The bottlenose dolphin (S. Leatherwood and R. R. Reeves, eds.), Academic Press, Inc., San Diego, xviii +653 pp.

Collum, L. A., AND T. H. FritTs. 1985. Sperm whales (Physeter catodon) in the Gulf of Mexico. Southwestern Nat., 30:101-104.

ELLIS, R. 1986. A guide to marine mammals of the Texas coast. Texas Parks Wildlife, 44(11):36-37.

JENNINGS, R. 1982. Pelagic sightings of Risso's dolphin, Grampus griseus, in the Gulf of Mexico and Atlantic Ocean adjacent to Florida. J. Mamm., 63:522-523.

MEAD, J. G. 1986. Twentieth-century records of right whales (Eubalaena glacialis) in the northwestern Atlantic Ocean. Pp. 109-119, in Right whales: past and present status (R. L. Brownell, P. B. Best., and J. H. Prescott, eds.), Rept. Internat. Whaling Comm., Spec. Issue, 10:vi + 1-289.

1989. Beaked whales of the genus Mesoplodon. Handbook Marine Mamm., 4:349-430.

MEAD, J. G., AND C. W. POTTER. 1990. Natural history of bottlenose dolphins along the central Atlantic Coast of the United States. Pp. 165-195, in The bottlenose dolphin (S. Leatherwood and R. R. Reeves, eds.), Academic Press, Inc., San Diego, xviii + 653 pp.

Perrin, W. F., E. D. Mitchell, J. G. Mead, D. K. Caldwell, and P. J. H. van Bree. 1981. Stenella clymene, a rediscovered tropical dolphin of the Atlantic. J. Mamm., 62:583-598.

SCHMidLy, D. J. 1981. Marine mammals of the southeastern United States coast and the Gulf of Mexico. U.S. Fish Wildlife Serv., Washington, D. C., viii + 165 pp. (processed).

SCOTT, G. P. 1990. Management-oriented research on bottlenose dolphins by the Southeast Fisheries Center. Pp. 623-639, in The bottlenose dolphin (S. Leatherwood and R. R. Reeves, eds.), Academic Press, Inc., San Diego, xviii + 653 pp. 
SHANE, S. H. 1990. Comparison of bottlenose dolpin behavior in Texas and Florida, with a critique of methods for studying dolphin behavior. Pp. 541-558, in The bottlenose dolphin (S. Leatherwood and R. R. Reeves, eds.), Academic Press, Inc., San Diego, xviii + 653 pp.

TARPLEY, R. J., AND S. R. MARWITZ. 1986. The mystery of stranded marine mammals. Texas Parks Wildlife, 44(1):32-35.

\section{CARnivora}

ANDELT, W. F. 1985. Behavioral ecology of coyotes in South Texas. Wildlife Monogr., 94:1-45.

ANDELT, W. F., AND S. H. ANDELT. 1984. Diet bias in scat deposition-rate surveys of coyote density. Wildlife Soc. Bull., 12:74-77.

ANDELT, W. F., C. E. HarRis, AND F. C. KNOWLton. 1985. Prior trap experience might bias coyote responses to scent stations. Southwestern Nat., 30:317-318.

ANDELt, W. F., J. G. KiE, F. F. KNowlton, AND K. Cardwell. 1987. Variation in seasonal diets associated with season and successional changes in vegetation. J. Wildlife Manag., 51:273-277.

BEAN, J. R. 1981. Indices of predator abundance in the westeru United States, 1981. U. S. Fish Wildlife Serv., Denver, 103 pp.

Bishop, T., AND M. E. TEwES. 1988. Landscape ecology of ocelots in the Rio Grande Valley. Caesar Kleberg Res. Prog. Wildlife Ecol., Ann. Rept. Texas Agric. Exp. Sta., p. 41.

1989. Ocelot use of corridors and habitat islands in South Texas. Caesar Kleberg Res. Prog. Wildlife Ecol., Ann. Rept. Texas Agric. Exp. Sta., p. 30.

1990. Ocelot use of corridors and habitat islands. Caesar Kleberg Res. Prog. Wildlife Ecol., Ann. Rept. Texas Agric. Exp. Sta., pp. 28-29.

Bluett, R. D., AND M. E. Tewes. 1988. Status and management needs of the bobcat in Texas. Caesar Kleberg Res. Prog. Wildlife Ecol., Ann. Rept. Texas Agric. Exp. Sta., p. 39.

BLuETT, R. D., L. L. LAACK, AND M. E. TEWES. 1989a. Overlap of bobcat and ocelot home ranges in South Texas. Caesar Kleberg Res. Prog. Wildlife Ecol., Ann. Rept. Texas Agric. Exp. Sta., pp. 31-32.

- 1989b. Home range and movement of bobcats in South Texas. Caesar Kleberg Res. Prog. Wildlife Ecol., Ann. Rept. Texas Agric. Exp. Sta., p. 32.

_ 1990a. Ecology of bobcats in South Texas. Caesar Kleberg Res. Prog. Wildlife Ecol., Ann. Rept. Texas Agric. Exp. Sta., pp. 27-28.

1990b. Competition between bobcats and ocelots. Caesar Kleberg Res. Prog. Wildlife Ecol., Ann. Rept. Texas Agric. Exp. Sta., p. 28.

Bluett, R. D., M. E. Tewes, AND B. C. Thompson. 1989. Geographic distribution of commercial bobcat harvests in Texas, 1978-1986. Texas J. Sci., 41:379-385.

Bluett, R. D., B. C. Thompson, AND M. E. Tewes. 1989. Status and management needs of the bobcat in Texas. Caesar Kleberg Res. Prog. Wildlife Ecol., Ann. Rept. Texas Agric. Exp. Sta., p. 32.

BRADLEY, L. C., AND D. B. FAGRE. 1988a. Coyote and bobcat responses to integrated ranch management practices in South Texas. J. Range Manag., 41:322-327.

1988b. Movements and habitat use by coyotes and bobcats on a ranch in southern Texas. Proc. Southeastern Assoc. Fish Wildlife Agencies, 42:411-430.

Brown, D. E. (ed.). 1983. The wolf in the Southwest.... Univ. Arizona Press, Tuscson, xii + 195 pp. Brown, D. E. 1985. The grizzly in the Southwest... Univ. Oklahoma Press, Norman, xix +274 pp. CASO, A., AND M. E. TEwES. 1990. Ecology of the jaguarundi in Tamaulipas, Mexico. Caesar Kleberg Res. Prog. Wildlife Ecol., Ann. Rept. Texas Agric. Exp. Sta., p. 28. 
CURRIER, M. J. P. 1983. Felis concolor. Mamm. Species, 200:1-7.

Davis, W. B. 1984. Cats of Texas. Texas Parks Wildlife Dept., Austin, 4 pp.

Dragoo, J. W., J. R. ChOATE, T. L. YateS, AND T. P. O'Farrell. 1990. Evolutionary and taxonomic relationships among North American arid-land foxes. J. Mamm., 71:318-332.

Dragoo, J. W., D. B. Frage, D. J. Schmidly, and L. B. Penry. 1989. First specimen of a hognosed skunk (Conepatus mesoleucus) from Bexar County, Texas. Texas J. Sci., 41:331333.

Eastland, W. G., AND S. L. Beasom. 1986a. Potential secondary hazards of compound 1080 to three mammalian scavengers. Wildlife Soc. Bull., 14:232-233.

1986b. Effects of ambient temperature on the 1080-LD 50 of raccoons. Wildlife Soc. Bull., 14:234-235.

ENGSTROM, M. D., AND T. C. MAXWELL. 1988. Records of mountain lion (Felis concolor) from the western Edwards Plateau of Texas. Texas J. Sci., 40:450-452.

EvereTt, D. D., AND M. Tewes. 1982. Study of endangered ocelot occurring in Texas. Caesar Kleberg Res. Prog. Wildlife Ecol., Ann. Rept. Texas Agric. Exp. Sta., p. 6.

1983. Study of the endangered ocelot occurring in Texas. Caesar Kleberg Res. Prog. Wildlife Ecol., Ann. Rept. Texas Agric. Exp. Sta., pp. 22-23.

EveretT, D. D., AND D. NAVARRo. 1983. Distribution, status, and ecology of the ocelot and jaguarundi in Texas. Caesar Kleberg Res. Prog. Wildlife Ecol., Ann. Rept. Texas Agric. Exp. Sta., p. 24.

Fagre, D., D. Martin, S. L. Beasom, J. Heffelfinger, S. Coughlin, and C. A. Deyoung. 1987. Evaluation of scent stations as a method to estimate coyote populations. Caesar Kleberg Res. Prog. Wildlife Ecol., Ann. Rept. Texas Agric. Exp. Sta., p. 20.

1988. Evaluation of scent stations as a method to estimate coyote populations. Caesar Kleberg Res. Prog. Wildlife Ecol., Ann. Rept. Texas Agric. Exp. Sta., p. 15.

1989. Evaluation of scent stations as a method to estimate coyote populations. Caesar Kleberg Res. Prog. Wildlife Ecol., Ann. Rept. Texas Agric. Exp. Sta., p. 34.

Fritzell, E. K., AND K. J. HAROLDSON. 1982. Urocyon cinereoargenteus. Mamm. Species, 189:1-8.

Guthrey, F. S., W. P. MEInZER, JR., S. L. BEasom, AND M. CARoline. 1984. Evaluation of placed baits for reducing coyote damage in Texas. J. Wildlife Manag., 48:621-626.

HAMMER, M., L. L. LAACK, AND M. E. TEWES. 1988. Food habits and prey availability of ocelots. Caesar Kleberg Res. Prog. Wildlife Ecol., Ann. Rept. Texas Agric. Exp. Sta., pp. 40-41.

HENKE, S. E., AND F. C. BRYANT. 1990. The effects of coyote control on predator-prey interactions. Research Highlights - 1990, Noxious Brush and Weed Control, Texas Tech Univ., 21:19.

Johnson, D. G., AND M. R. PELton. 1981. A survey of procedures to determine relative abundance of furbearers in the southeastern United States. Proc. Southeastern Assoc. Fish Wildlife Agencies, 35:261-272.

JoNES, J. K., JR., R. R. Hollander, AND D. A. MCCullough. 1985. Records of the spotted skunk and long-tailed weasel from the Llano Estacado of Texas. Texas J. Sci., 37:355-358.

JUEN, J., AND C. D. SIMPSON. 1981. Home range, movement, and denning sites of raccoons on the Texas High Plains. Research Highlights-1981, Noxious Brush and Weed Control. Texas Tech Univ., 12:48.

KENNEDY, M. L., AND S. L. LindSAY. 1984. Morphologic variation in the raccoon, Procyon lotor, and its relationship to genic and environmental variation. J. Mamm., 65:195-205.

KenNedy, M. L., P. L. LebERG, AND G. D. BaUmGardner. 1986. Morphologic variation in the coyote, Canis latrans, in the southern United States. Southwestern Nat., 31:139-148. 
KNowlton, F. F., L. A. WindBerg, AND C. E. WAHLgREN. 1986. Coyote vulnerability to several management techniques. Pp. 165-176, in Proc. 7th Great Plains Wildlife Damage Control Workshop (D. B. Fagre, ed.), Texas A\&M Univ., College Station, 203 pp.

KUBAN, J. F., AND G. G. SCHWARTZ. 1985. Nectar as a diet item of the ringtailed cat. Southwestern Nat., 30:311-312.

LaACK, L. L., AND J. H. RaPPOLE. 1985. Ecology of the ocelot in South Texas. Caesar Kleberg Res. Prog. Wildlife Ecol., Ann. Rept. Texas Agric. Exp. Sta., p. 36.

1986. Tracking ocelots with fluorescent pigments. Caesar Kleberg Res. Prog. Wildlife Ecol., Ann. Rept. Texas Agric. Exp. Sta., p. 34.

1987. Ecology of the ocelot in South Texas. Caesar Kleberg Res. Prog. Wildlife Ecol., Ann. Rept. Texas Agric. Exp. Sta., p. 35.

LAACK, L. L., AND M. E. TEWES. 1988a. Utility of translocation for the ocelot recovery program. Caesar Kleberg Res. Prog. Wildlife Ecol., Ann. Rept. Texas Agric. Exp. Sta., p. 40.

$1988 b$. Genetic variability of a fragmented ocelot population. Caesar Kleberg Res. Prog. Wildlife Ecol., Ann. Rept. Texas Agric. Exp. Sta., p. 41.

1989. Utility of translocation for the ocelot recovery program. Caesar Kleberg Res. Prog. Wildlife Ecol., Ann. Rept. Texas Agric. Exp. Sta., p. 29.

1990. Utility of translocation for the ocelot recovery program. Caesar Kleberg Res. Prog. Wildlife Ecol., Ann. Rept. Texas Agric. Exp. Sta., pp. 29-30.

LAACK, L. L., M. E. TEWES, AND J. H. Rappole. 1989. Den ecology of ocelots. Caesar Kleberg Res. Prog. Wildlife Ecol., Ann. Rept. Texas Agric. Exp. Sta., pp. 29-30.

1990. Den ecology and adult-subadult interactions of ocelots. Caesar Kleberg Res. Prog. Wildlife Ecol., Ann. Rept. Texas Agric. Exp. Sta., p. 29.

Leopold, B. D., AND P. R. Krausman. 1986. Diets of 3 predators in Big Bend National Park, Texas. J. Wildlife Manag., 50:290-295.

LinharT, S. B. 1981. Field evaluation of techniques for reducing coyote predation on livestock. Proc. Worldwide Furbearer Conf. (J. A. Chapman and D. Pursley, eds.), 1:1826-1838 (processed).

LinHART, S. B., G. J. DASCH, AND F. J. TURKOWSKI. 1981. The steel leg-hold trap: techniques for reducing foot injury and increasing selectivity. Proc. Worldwide Furbearer Conf. (J. A. Chapman and D. Pursley, eds.), 1:1560-1578 (processed).

Linhart, S. B., F. S. Blom, G. D. DASCh, AND R. M. EngEMAN. 1988. Field evaluation of padded jaw coyote traps: effectiveness and foot injury. Proc. Vert. Pest Conf. (A. C. Crabb and R. E. Marsh, eds.), Univ. California, Davis., 13:226-229.

Linhart, S. B., G. J. DASCh, C. B. MALE, AND R. M. ENGEMAN. 1986. Efficiency of unpadded steel foothold traps for capturing coyotes. Wildlife Soc. Bull, 14:212-218.

LYDEARD, C., AND M. L. KENNEDY. 1988. Morphologic assessment of recently founded populations of the coyote, Canis latrans, in Tennessee. J. Mamm., 69:773-781.

MARTIN, D. J., AND D. B. FAGRE. 1988. Field evaluation of a synthetic coyote attractant. Wildlife Soc. Bull., 16:390-396.

MCCRACKEN, G. F., M. K. GuSTIN, AND M. I. MCKAMEY. 1986. Raccoons catch Mexican freetailed bats "on the wing." Bat Res. News, 27:21-22.

Meinzer, W. P., JR., F. S. Guthery, S. L. Beasom, and M. Caroline. 1982. Effectiveness of place baits for coyote damage control. Research Highlights-1982, Noxious Brush and Weed Control, Texas Tech Univ., 13:52.

MANNING, R. W., J. K. JONES, JR., AND R. R. Hollander. 1986. Northern limits of distribution of the hognosed skunk, Conepatus mesoleucus, in Texas. Texas J. Sci., 38:289-291.

NASS, R. D., G. LYNCH, AND J. THEADE. 1984. Circumstances associated with predation rates on sheep and goats. J. Range Manage., 37:423-426. 
NAVARRO-LOPEZ, D., AND J. H. RAPPOLE. 1985. South Texas status and zoogeography of the ocelot. Caesar Kleberg Res. Prog. Wildlife Ecol., Ann. Rept. Texas Agric. Exp. Sta., p. 35.

Navarro-Lopez, D., M. Tewes, D. D. EveretT, AND J. H. Rappole. 1984. Historic and pre-historic distribution of the ocelot in North America. Caesar Kleberg Res. Prog. Wildlife Ecol., Ann. Rept. Texas Agric. Exp. Sta., p. 33.

NunLEY, G. L. 1981. Emergency use request of compound 1080 bait station in Texas for the control of coyotes. Texas Rodent Predatory Animal Control Serv., San Antonio, 22 pp.

Olsen, G. H., S. B. Linhart, R. A. Holmes, G. J. Dasch, and C. B. Male. 1986. Injuries to coyotes caught in padded and unpadded steel foothold traps. Wildlife Soc. Bull., 14:219-223.

Pearson, E. W., AND M. Caroline. 1981. Predator control in relation to livestock losses in central Texas. J. Range Manage., 34:435-441.

Poglayen-Neuwall, I., AND D. E. Toweill. 1988. Bassariscus astutus. Mamm. Species, 327:1-8.

RADOMSKI, A. A., AND D. B. PENCE. 1988. Community ecology of gastrointestinal helminths of coyotes. Research Highlights-1988, Noxious Brush and Weed Control, Texas Tech Univ., 19:37.

RapPole, J. H. 1985. Extensive survey for the ocelot and jaguarundi in South Texas. Caesar Kleberg Res. Prog. Wildlife Ecol., Ann. Rept. Texas Agric. Exp. Sta., p. 36.

RAPPOLE, J. H., AND D. NAVARRO-LOPEZ. 1984. Development of a remote-trip camera for recording the presence of ocelots and jaguarundis. Caesar Kleberg Res. Prog. Wildlife Ecol., Ann. Rept. Texas Agric. Exp. Sta., p. 34.

RAPPOLE, J. H., AND M. E. TEWES. 1985. Ocelot habitat use at the Laguna Atascosa National Wildlife Refuge. Caesar Kleberg Res. Prog. Wildlife Ecol., Ann. Rept. Texas Agric. Exp. Sta., pp. 35-36.

RILEY, D. G. 1989. Controlling raccoon damage in urban areas. Proc. Great Plains Wildlife Damage Control Workshop, 9:85-86 (processed).

RITKE, M. E. 1990. Sexual dimorphism in the raccoon (Procyon lotor): morphological evidence for intrasexual selection. Amer. Midland Nat., 124:342-351.

RITKE, M. E., AND M. L. KENNEDY. 1988. Intraspecific morphologic variation in the raccoon (Procyon lotor) and its relationship to selected environmental variables. Southwestern Nat., 33:295-314.

SChmidLy, D. J., AND J. A. READ. 1986. Cranial variation in the bobcat (Felis rufus) from Texas and surrounding states. Occas. Papers Mus., Texas Tech Univ., 101:1-39.

SCRIVNER, J. H. 1983. Reducing goat losses to predators: past vs. present producers in Texas. Great Plains Wildlife Damage Control Workshop, 6:83-91 (processed).

1984. The 1080 toxic collar: economics of field use in Texas. Proc. Eastern Wildlife Damage Control Conf., 1:201-204.

SCRIVNER, J. H., AND J. R. CONNER. 1984. Costs and returns of angora goat enterprises with and without coyote predation. J. Range Manag., 37:166-171.

SeYmour, K. L. 1989. Felis onca. Mamm. Species, 340:1-9.

SWEPSTON, D. A. 1981. New records of the red fox (Vulpes vulpes) in West Texas. Southwestern Nat., 25:565.

TEWES, M. E. 1983. Ocelot and jaguarundi-brush country cats. Texas Parks Wildlife, 4l(2):2-5. 1989. Consultation on the endangered cats. Caesar Kleberg Res. Prog. Wildlife Ecol., Ann. Rept. Texas Agric. Exp. Sta., p. 31.

1990a. Cat country. Texas Parks Wildlife, 48(11):4-11.

$1990 \mathrm{~b}$. Public education and consultation on the endangered cats. Caesar Kleberg Res. Prog. Wildlife Ecol., Ann. Rept. Texas Agric. Exp. Sta., p. 27. 
1990c. The feline research program. Caesar Kleberg Res. Prog. Wildlife Ecol., Ann. Rept. Texas Agric. Exp. Sta., p. 27.

1990d. Habitat mapping for the ocelot in South Texas. Caesar Kleberg Res. Prog. Wildlife Ecol., Ann. Rept. Texas Agric. Exp. Sta., p. 28.

TEWES, M. E., AND D. D. EvERETT. 1983. Status and distribution of the endangered ocelot and jaguarundi in Texas. Pp. 147-158, in Cats of world: biology, conservation, and management (S. D. Miller and D. D. Everett, eds.), Nat. Wildlife Fed., Washington, D. C., xi + 501 pp.

TEWES, M. E., AND M. HoRNOCKER. 1985. Ecology of the ocelot in Texas. Welder Wildlife Foundation Biennial Rept., p. 14.

Tewes, M. E.,AND S. D. Miller. 1988. The feline research program of South Texas. Caesar Kleberg Res. Prog. Wildlife Ecol., Ann. Rept. Texas Agric. Exp. Sta., p. 39.

1989. The feline research program of South Texas. Caesar Kleberg Res. Prog. Wildlife Ecol., Ann. Rept. Texas Agric. Exp. Sta., p. 29.

TEWES, M. E., AND D. J. SCHMIDLY. 1987a. The neotropical felids: jaguar, ocelot, margay, and jaguarundi. Pp. 696-712, in Wild furbearer management and conservation in North America (M. Novak, J. A. Baker, M. E. Obbard, and B. Malloch, eds.), Ontario Min. Nat. Resources, xviii +1150 pp.

1987b. Literature survey and management of 4 Texas tropical cats. Caesar Kleberg Res. Prog. Wildlife Ecol., Ann. Rept. Texas Agric. Exp. Sta., p. 36.

1988. Literature survey and management of 4 Texas tropical cats. Caesar Kleberg Res. Prog. Wildlife Ecol., Ann. Rept. Texas Agric. Exp. Sta., p. 41.

Tewes, M. E., AND J. M. SCOTT. 1987. Bobcat harvest in the Western United States, 1975-86. Caesar Kleberg Res. Prog. Wildlife Ecol., Ann. Rept. Texas Agric. Exp. Sta., p. 35.

1988. Bobcat harvest in the Western United States. Caesar Kleberg Res. Prog. Wildlife Ecol., Ann. Rept. Texas Agric. Exp. Sta., pp. 18-19.

Tewes, M. E., D. D. EveretT, AND J. H. Rappole. 1984. Ecology of the ocelot in South Texas. Caesar Kleberg Res. Prog. Wildlife Ecol., Ann. Rept. Texas Agric. Exp. Sta., p. 33.

1987. Ecological and behavioral patterns of ocelots, 1982-85. Caesar Kleberg Res. Prog. Wildlife Ecol., Ann. Rept. Texas Agric. Exp. Sta., p. 34.

TEWES, M. E., L. L. LAACK, AND J. H. RAPPOLE. 1989. Long-term studies of ocelot ecology and behavior in Texas. Caesar Kleberg Res. Prog. Wildlife Ecol., Ann. Rept. Texas Agric. Exp. Sta., p. 31.

ToweILl, D. E., AND J. G. TEER. 1981. Home range and den habits of Texas ringtails (Bassariscus astatus flavus). Proc. Worldwide Furbearer Conf., 1:1103-1120 (processed).

TURKowSKI, F. J., A. R. ARMISTED, AND J. B. LiNhART. 1984. Selectivity and effectiveness of pan tension devices for coyote foothold traps. J. Wildlife Manag., 48:700-708.

TURKowsKi, F. J., M. L. PopelCA, AND R. W. BullaRD. 1982. Efficacy of odor lures and baits for coyotes. Wildlife Soc. Bull., 10:136-145.

TwEDT, D., AND J. H. RAPPOLE. 1986. Extensive survey for the ocelot and jaguarundi in South Texas. Caesar Kleberg Res. Prog. Wildlife Ecol., Ann. Rept. Texas Agric. Exp. Sta., p. 33.

TwedT, D. J., L. L. LAACK, AND J. H. RAPPOLE. 1987. Distribution of the ocelot and jaguarundi in South Texas. Caesar Kleberg Res. Prog. Wildlife Ecol., Ann. Rept. Texas Agric. Exp. Sta., pp. 34-35.

Wade, D. A., D. W. Hawthorne, G. L. Nunley, AND M. Caroline. 1984. History and status of predator control in Texas. Proc. Vert. Pest Conf., 11:122-131.

WAdE-Smith, J., AND B. J. VerTs. 1982. Mephitis mephitis. Mamm. Species, 173:1-7.

WALSH, P. B., AND J. M. INGLIS. 1989. Seasonal and diel rate of spontaneous vocalization in coyotes in South Texas. J. Mamm., 70:169-171. 
Walton, M. T. 1989. Texas Department of Agriculture predator management program. Proc. Great Plains Wildlife Damage Control Workshop, 9:44-49 (processed).

WAHLGREN, C. E., L. A. WINDBERG, AND S. L. BEASOM. 1984. Influence of territorial status on reproductive success and bait acceptance of coyotes in South Texas. Caesar Kleberg Res. Prog. Wildlife Ecol., Ann. Rept. Texas Agric. Exp. Sta., p. 34.

1985. Influence of territorial status on reproductive success and bait acceptance of coyotes in South Texas. Caesar Kleberg Res. Prog. Wildlife Ecol., Ann. Rept. Texas Agric. Exp. Sta., p. 25.

WAHLGREN, C. E., L. A. WINDBERG, AND F. F. KNOWLTON. 1985. Retention of biological markers in captive coyotes. Caesar Kleberg Res. Prog. Wildlife Ecol., Ann. Rept. Texas Agric. Exp. Sta., p. 43.

WaID, D. D., AND R. J. WARREN. 1983. Ecology of mountain lions in Big Bend National Park. Research Highlights-1983, Noxious Brush and Weed Control, Texas Tech Univ., 14:40.

WaID, D. D., D. B. PENCE, AND R. J. WARREN. 1985. The ecology of mountain lions in Big Bend National Park. Research Highlights-1985, Noxious Brush and Weed Control, Texas Tech Univ., 16:35-36.

- 1986. The ecology of mountain lions in Big Bend National Park. Research Highlights1986, Noxious Brush and Weed Control, Texas Tech Univ., 17:35.

WaiD, D. D., R. J. WARREN, AND D. B. PEnCE. 1984. Ecology of mountain lions in Big Bend National Park. Research Highlights-1984, Noxious Brush and Weed Control, Texas Tech Univ., 15:38-39.

- 1985. Ecology of mountain lions in the vicinity of Big Bend National Park and the TransPecos region of Texas. Caesar Kleberg Found. Wildlife Conserv., Ann. Rept., Texas Tech Univ., 6:11-12.

Whiteside, R. W., AND F. S. Guthrey. 1981a. Coyote use of playas in the Texas High Plains. Prairie Nat., 13:42-44.

1981b. Coyote use of playas in the Texas Panhandle. Research Highlights-1981, Noxious Brush and Weed Control, Texas Tech Univ., 12:48-49.

WILCOX, D., AND F. C. BRYANT. 1982. Cultivated forages for supplementing mule deer habitat in the Texas Panhandle. Caesar Kleberg Found. Wildlife Conserv., Ann. Rept., Texas Tech Univ., 3:3-4.

WindBERG, L. A., AND F. F. KNOWLTON. 1988. Management implications of coyote spacing patterns in southern Texas. J. Wildlife Manag., 52:632-640.

WindBERG, L. A., AND C. D. MitChELL. 1990. Winter diets of coyotes in relation to prey abundance in southern Texas. J. Mamm., 71:439-447.

WindBerG, L. A., H. L. ANDERSON, AND R. M. ENGEMAN. 1985. Survival of coyotes in southern Texas. J. Wildlife Manag., 49:301-307.

WINDBERG, L. A., S. L. BEASOM, AND C. E. WAHLGREN. 1983. The relationship between territorial status and reproductive success of coyotes. Caesar Kleberg Res. Prog. Wildlife Ecol., Ann. Rept. Texas Agric. Exp. Sta., p. 12.

WILLEY, R. B., AND R. E. RICHARDS. 1981. Vocalizations of the ringtail (Bassariscus astutus). Southwestern Nat., 26:23-30.

\section{SIRENIA}

Fernandez, S., AND S. C. Jones. 1990. Manatee stranding on the coast of Texas. Texas J. Sci., 42:103. 


\section{ARTIODACTYLA}

AвbotT, M. J., AND R. D. Brown. 1984. Physiological and physical indices of the nutritional condition of white-tailed deer. Caesar Kleberg Res. Prog. Wildlife Ecol., Ann. Rept. Texas Agric. Exp. Sta., pp. 15-16.

AdAmS, C. E., AND J. K. Thomas. 1985. Socioeconomic factors affecting land access to hunt white-tailed deer. Wildlife Soc. Bull., 13:388-394.

ADAMS, N. E., JR. 1988. Hunting management to achieve ranch goals on the Welder and McCan Ranch, Texas. Proc. 1988 Internat. Ranchers Roundup, San Antonio, pp. 121-127 (processed).

ALLEN, C. 1982. Analysis of an East Texas quality or "trophy" white-tailed deer management program. P. 11, in Fifth Ann. Meeting Southeast Deer Study Group, Charleston, South Carolina, $24 \mathrm{pp}$.

ANDERSON, A. E., AND O. C. Wallmo. 1984. Odocoileus hemionus. Mamm. Species, 219:1-9.

ARMSTRONG, W. E. 1981. White-tailed deer competition with goats, sheep, cattle and exotic wildlife. Proc. 1981 Internat. Ranchers Roundup, Del Rio, Texas, pp. 343-348 (processed). 1984a. Key foot plants for deer-Edwards Plateau. Proc. 1984 Internat. Ranchers Roundup, San Angelo, Texas, pp. 277-280 (processed).

1984b. How to manage deer habitat: Edwards Plateau. Proc. 1984 Internat. Ranchers Roundup, San Angelo, Texas, pp. 316-327 (processed).

BACCUS, J. T., AND R. D. WeLCH. 1983. Asymmetry in the antler structure of sika deer from the Edwards Plateau of Texas. Pp. 211-222, in Antler development in Cervidae (R. D. Brown, ed.), Proc. First Internat. Symp. Caesar Kleberg Wildlife Res. Inst., Kingsville, Texas, xiii $+480 \mathrm{pp}$.

BAER, D. J., AND R. D. BROWN. 1987. Volatile fatty acids in the digestive tract of the collared peccary. Caesar Kleberg Res. Prog. Wildlife Ecol., Ann. Rept. Texas Agric. Exp. Sta., p. 34.

BAILEY, M. A., AND S. DemaraIS. 1987. Dietary interactions among native and exotic deer in the Edwards Plateau region. Research Highlights-1987, Noxious Brush and Weed Control, Texas Tech Univ., 18:30.

BAKER, R. H. 1984. Origin, classification and distribution. Pp. 1-18, in White-tailed deer ecology and management (L. K. Halls, ed.), Wildlife Manag. Inst., Washington, D. C., and Stackpole Books, Harrisburg, Pennsylvania, xxiii +870 pp.

BAREISS, L. J., AND C. A. DeYoung. 1986. Mortality rates and causes in white-tailed bucks on 2 South Texas ranches. Caesar Kleberg Res. Prog. Wildlife Ecol., Ann. Rept. Texas Agric. Exp. Sta., p. 21.

Bareiss, L. J., D. S. DAVIS, AND R. D. Brown. 1985. Mortality of white-tailed bucks on 2 South Texas ranches. Caesar Kleberg Res. Prog. Wildlife Ecol., Ann. Rept. Texas Agric. Exp. Sta., p. 24.

BAREISS, L. J., T. FUlBRIGHT, AND S. L. BEASOM. 1985. Roller-chopping to improve white-tailed deer habitat. Caesar Kleberg Res. Prog. Wildlife Ecol., Ann. Rept. Texas Agric. Exp. Sta., pp. 2-3.

_ 1986a. Roller chopping to improve white-tailed deer habitat. Caesar Kleberg Res. Prog. Wildlife Ecol., Ann. Rept. Texas Agric. Exp. Sta., pp. 8-9.

1986b. Condition of white-tailed deer after roller chopping of brush. Caesar Kleberg Res. Prog. Wildlife Ecol., Ann. Rept. Texas Agric. Exp. Sta., p. 9.

Barnes, T. G., L. W. Varner, L. H. Blankenship, T. J. Fillinger, and S. C. Heineman. 1990. Macro and trace mineral content of selected South Texas deer forages. J. Range Manag., 43:220-223. 
Barnett, D. A., S. Demarais, And R. Zaiglin. 1985. Orphaning effects of white-tailed deer fawns in South Texas. Research Highlights-1985, Noxious Brush and Weed Control, Texas Tech Univ., 16:39.

BARNETT, D. A., F. ZAIGLIN, AND S. Demarais. 1985. Home range and activity patterns of mature male white-tailed deer in South Texas. Research Highlights-1985, Noxious Brush and Weed Control, Texas Tech Univ., 16:37-38.

1986. Home range of adult male white-tailed deer in south Texas-preliminary results. P. 18, in Ninth Annual Meeting Southeast Deer Study Group, Gatlinburg, Tennessee, 20 pp.

BarnetT, D. A., M. L. Richardson, S. Demarais, And R. E. ZaiGlin. 1987. An effective expansible transmitter collar for white-tailed deer fawns. Research Highlights-1987, Noxious Brush and Weed Control, Texas Tech Univ., 18:34-35.

BARTUSH, B., AND C. A. DeYOUNG. 1989. Mortality in female white-tailed deer on Fort Sill, Oklahoma. Caesar Kleberg Res. Prog. Wildlife Ecol., Ann. Rept. Texas Agric. Exp. Sta., p. 3.

BEASOM, S. L. 1981. Habitat interrelationships between mule and white-tailed deer in fenced enclosure. Research Highlights-1981, Noxious Brush and Weed Control, Texas Tech Univ., 12:72-73.

1984. Response of white-tailed deer to roller chopping of brush. Caesar Kleberg Res. Prog. Wildlife Ecol., Ann. Rept. Texas Agric. Exp. Sta., p. 2.

BEASOM, S. L., AND J. D. BURD. 1981. Ear tag retention in mule and white-tailed deer. Research Highlights-1981, Noxious Brush and Weed Control, Texas Tech Univ., 12:73.

1983. Retention and visibility of plastic ear tags on deer. J. Wildlife Manag., 47:1201-1203.

BEASOM, S. L., AND J. L. INGLIS. 1981. Deer response to herbicidal treatment of a wooded bottomland habitat. P. 7, in Fourth Ann. Meeting Southeast Deer Study Group, Tallahassee, Florida, 20 pp.

BEASOM, S. L., AND L. J. KRYSL. 1981. Diet similarity of mule and white-tailed deer in a fenced enclosure. Research Highlights-1981, Noxious Brush and Weed Control, Texas Tech Univ., 12:68.

BEASOM, S. L., AND F. G. LEON, III. 1983. Evaluation of spotlight, fixed-wing aircraft, and helicopter censusing of white-tailed deer. Caesar Kleberg Res. Prog. Wildlife Ecol., Ann. Rept. Texas Agric. Exp. Sta., p. 11.

BEASOM, S. L., AND M. D. SPRINGER. 1981. Response of deer body quality to prescribed burning in southeast Texas. P. 10, in Fourth Ann. Meeting Southeast Deer Study Group, Tallahassee, Florida, $20 \mathrm{pp}$.

BEASOM, S. L., AND B. WANGLER, 1981. Hair scale characteristics of selected ungulate species in the southwestern U.S. Research Highlights-1981, Noxious Brush and Weed Control, Texas Tech Univ., 12:78-79.

BeAsom, S. L., AND E. P. WigGers. 1981. Productivity of mule and white-tailed deer. Research Highlights-1981, Noxious Brush and Weed Control, Texas Tech Univ., 12:73.

BeAsom, S. L., J. BRUNer, AND E. Davis. 1985. Determining sustainable yield in white-tailed deer through experimental harvest. Caesar Kleberg Res. Prog. Wildlife Ecol., Ann. Rept. Texas Agric. Exp. Sta., p. 23.

BeAsom, S. L., T. Fulbright, AND J. A. BAZzo. 1988. Wildlife habitat development: deer and quail. Caesar Kleberg Res. Prog. Wildlife Ecol., Ann. Rept. Texas Agric. Exp. Sta., p. 25.

BEASOM, S. L., J.C. HoOD, AND J. R. CAIN. 1981. The effect of strip width on helicopter censusing of deer. J. Range Manag., 34:36-37.

BEASOM, S. L., J. M. INGLIS, AND C. J. SCIFRES. 1982. Vegetation of white-tailed deer responses to herbicide treatment of a mesquite drainage habitat type. J. Range Manag., 35:790-794.

BEASOM, S. L., L. LAPLANT, AND V. W. HowARD, JR. 1982. Fecal pH of pronghorn and sheep as related to diet. J. Wildlife Manag., 46:1101-1103. 
BEASOM, S. L., F. LEON, AND D. P. SYNATYSKE. 1986. Accuracy and precision of censusing whitetailed deer by helicopter. Wildlife Soc. Bull., 14:364-368.

BEASOM, S. L., B. WANGLER, AND D. Rollins. 1981. Identification of ungulate feces by hair content. Research Highlights-1981, Noxious Brush and Weed Control, Texas Tech Univ., 12:79-80.

Beasom, S. L., D. D. EveretT, A. J. GARZA, JR., AND T. F. Kohl. 1983. Response of white-tailed deer, turkeys, and bobwhite quail to short duration grazing by cattle. Caesar Kleberg Res. Prog. Wildlife Ecol., Ann. Rept. Texas Agric. Exp. Sta., p. 10.

BisSONETTE, J. A. 1982. Ecology and social behavior of the collared peccary in Big Bend National Park. Sci. Monogr. Ser., Nat. Park Serv., U. S. Dept. Interior, 16:xi + 1-85.

BLAIR, R. M., R. ALCANIZ, AND H. F. MORRIS, JR. 1984. Yield, nutrient composition, and ruminent digestibility of fleshy fungi in southern forests. J. Wildlife Manag., 48:1344-1352.

Blair, K., S. Demarais, AND D. N. UeKerT. 1985. Evaluation of food plots for deer in the Rolling Plains of Texas. Research Highlights-1985, Noxious Brush and Weed Control, Texas Tech Univ., 16:36-37.

- 1986. Evaluation of food plots for deer in the Rolling Plains of Texas. Research Highlights-1986, Noxious Brush and Weed Control, Texas Tech Univ., 17:32.

- 1987. Evaluation of food plots for white-tailed deer in the Rolling Plains of Texas. Pp. 23-24, in Tenth Ann. Meeting Southeast Deer Study Group, Gulf Shores, Alabama, 30 pp.

Blankenship, L. H. 1981. Ranch management for deer and livestock. Proc. 1981 Internat. Ranchers Roundup, Del Rio, Texas, pp. 398-403 (processed).

BLANkenship, L. H., L. W. VARner, T. J. Fillinger, AND G. WAmPler. 1985. Competition for food among herbivores on Texas rangelands: preliminary report. Proc. First Internat. Wildlife Symp., Mexico City, 2:1020-1055.

Bone, T. L. 1983 Age composition and horn development of Texas pronghorns. Proc. Antelope State Workshop, 11:105-112.

Borden, B. D. 1981. Evaluation of the either-sex hunt concept in East Texas. Pp. 1-3, in Fourth Ann. Meeting Southeast Deer Study Group, Tallahassee, Florida, 20 pp.

Boydston, G.A., AND H. GoRE. 1987. Archery wounding rates: a synopsis. Pp. 16-17, in Tenth Ann. Meeting Southeast Deer Study Group, Gulf Shores, Alabama, 30 pp.

Bozzo, J. A., S. L. BEASOM, AND T. E. FulBriGHT. 1989a. Effects of discing whitebrush communities on white-tailed deer use. Caesar Kleberg Res. Prog: Wildlife Ecol., Ann. Rept. Texas Agric. Exp. Sta., p. 12.

1989b. Effects of roller chopping on white-tailed deer habitat use. Caesar Kleberg Res. Prog. Wildlife Ecol., Ann. Rept. Texas Agric. Exp. Sta., pp. 12-13.

$1990 a$. Effects of discing whitebrush communities on white-tailed deer use. Caesar Kleberg Res. Prog. Wildlife Ecol., Ann. Rept. Texas Agric. Exp. Sta., p. 17.

1990b. Effects of roller chopping on white-tailed deer habitat use. Caesar Kleberg Res. Prog. Wildlife Ecol., Ann. Rept. Texas Agric. Exp. Sta., p. 17.

BRADLEY, L. C., F. C. BRYANT, AND C. A. TAYLOR. 1989. Diet similarity among deer, goats and sheep in the Edwards Plateau. Research Highlights-1989, Noxious Brush and Weed Control, Texas Tech Univ., 20:33.

Brown, R. D. 1985a. Consumption of protein blocks by white-tailed deer. Caesar Kleberg Res. Prog. Wildlife Ecol., Ann. Rept. Texas Agric. Exp. Sta., p. 20.

1985b. Observations on the genetics of antler growth. Caesar Kleberg Res. Prog. Wildlife Ecol., Ann. Rept. Texas Agric. Exp. Sta., p. 24.

BRown, R. D., AND M. AвBOTT. 1985. Prediction of diet from physiological and physical indices in white-tailed deer-preliminary results. Caesar Kleberg Res. Prog. Wildlife Ecol., Ann. Rept. Texas Agric. Exp. Sta., p. 41. 
BROWN, R. D., AND D. BAER. 1985. Digestive physiology of the collared peccary. Caesar Kleberg Res. Prog. Wildlife Ecol., Ann. Rept. Texas Agric. Exp. Sta., pp. 40-41.

Brown, R. D., AND K. P. H. PrITZKER. 1985. Osteoporosis in white-tailed deer. Caesar Kleberg Res. Prog. Wildlife Ecol., Ann. Rept. Texas Agric. Exp. Sta., p. 39.

1986. Osteoporosis in white-tailed deer. Caesar Kleberg Res. Prog. Wildlife Ecol., Ann. Rept. Texas Agric. Exp. Sta., p. 28.

BROWN, R. D., AND D. SWAKON. 1981. The comparative degestive efficiency of deer, goats, cattle and horses. Caesar Kleberg Res. Prog. Wildlife Ecol., Ann. Rept. Texas Agric. Exp. Sta., p. 27.

BRown, R. D., AND C. WhEATON. 1981. Seasonal feed intake and digestive efficiency in whitetailed deer. Caesar Kleberg Res. Prog. Wildlife Ecol., Ann. Rept. Texas Agric. Exp. Sta., p. 24.

BROWN, R. D., AND V. K. ZBUZEK. 1987. Effect of water restriction on vasopressin levels in whitetailed deer. Caesar Kleberg Res. Prog. Wildlife Ecol., Ann. Rept. Texas Agric. Exp. Sta., p. 33.

Brown, R., M. ABbotT, AND R. Bingham. 1986. Effect of recent diet on physiological indices in white-tailed deer. Caesar Kleberg Res. Prog. Wildlife Ecol., Ann. Rept. Texas Agric. Exp. Sta., p. 30.

BRown, R., T. DAILEY, AND J. KIDWELL. 1986. Intramuscular vs. intravenous administration of yohimbine hydrochloride as an antidote for rompun in white-tailed deer. Caesar Kleberg Res. Prog. Wildlife Ecol., Ann. Rept. Texas Agric. Exp. Sta., p. 29.

Brown, R. D., K. V. D. EEmS, AND V. Ramirez. 1984. The effect of immobilizing agents on feed intake on white-tailed deer. Caesar Kleberg Res. Prog. Wildlife Ecol., Ann. Rept. Texas Agric. Exp. Sta., pp. 16-17.

Brown, R. D., A. J. GARZA, JR., AND G. CARL. 1981. The comparative digestive and nutrient requirements of javelina (collared peccary). Caesar Kleberg Res. Prog. Wildlife Ecol., Ann. Rept. Texas Agric. Exp. Sta., p. 28.

1982. The comparative digestive efficiency and nutrient requirements of javelina (collared peccary). Caesar Kleberg Res. Prog. Wildlife Ecol., Ann. Rept. Texas Agric. Exp. Sta., pp. 15-16.

1983. The comparative digestive efficiency and nutrient requirements of javelina (collared peccary). Caesar Kleberg Res. Prog. Wildlife Ecol., Ann. Rept. Texas Agric. Exp. Sta., p. 4.

Brown, R. D., A. J. Garza, JR., AND J. C. Priebe. 1981a. The effects of maternal nutrition on fawn growth and lactational performance of white-tailed deer in South Texas. Caesar Kleberg Res. Prog. Wildlife Ecol., Ann. Rept. Texas Agric. Exp. Sta., pp. 25-26.

1981b. The digestive efficiency and nutrient requirements of nilgai antelope. Caesar Kleberg Res. Prog. Wildlife Ecol., Ann. Rept. Texas Agric. Exp. Sta., p. 29.

1982a. The effects of maternal nutrition on fawn growth and lactational performance of white-tailed deer in South Texas. Caesar Kleberg Res. Prog. Wildlife Ecol., Ann. Rept. Texas Agric. Exp. Sta., p. 13.

1982b. The digestive efficiency and nutrient requirements of nilgai antelope. Caesar Kleberg Res. Prog. Wildlife Ecol., Ann. Rept. Texas Agric. Exp. Sta., p. 14.

1983. The digestive efficiency and nutrient requirements of nilgai antelope. Caesar Kleberg Res. Prog. Wildlife Ecol., Ann. Rept. Texas Agric. Exp. Sta.. p. 5.

Brown, R. D., M. W. MEYER, AND C. A. WhEATON. 1985. Nutritional management of whitetailed deer (Odocoileus virginianus) for hunting in South Texas. Pp. 428, in Biology of deer production (P. F. Fennessy and K. R. Drew, eds.), Proc. Internat. Conf., Dunedin, New Zealand., xiii +1482 pp. 
BRown, R., V. RAMIREZ, AND J. KIDWELL. 1986. Further investigations of deer antler tissue incubation. Caesar Kleberg Res. Prog. Wildlife Ecol., Ann. Rept. Texas Agric. Exp. Sta., p. 29.

Brown, R. D., J. Thompson, AND J. Russell. 1987. Mineral analysis of deer antler tissue by scanning electron microscope. Caesar Kleberg Res. Prog. Wildlife Ecol., Ann. Rept. Texas Agric. Exp. Sta., p. 32.

Brown, R. D., D. Stephenson, C. C. Chao, J. Melendez, L. Melendez, and L. Pearson. 1982. Biomedical implications of antlerogenesis in deer. Caesar Kleberg Res. Prog. Wildlife Ecol., Ann. Rept. Texas Agric. Exp. Sta., p. 10.

Brown, R. D., A. J. Garza, JR., D. Stephenson, C. C. Chao, J. Melendez, L. Melendez, AND M. MELENDEZ. 1983. Biomedical implications of antlerogenesis in deer. Caesar Kleberg Res. Prog. Wildlife Ecol., Ann. Rept. Texas Agric. Exp. Sta., pp. 1-3.

Brown, R. D., D. Stephenson, L. Hubert, C. C. Chao, A. Salinas, L. Gonzalez, and L. PearSON. 1981. The biomedical implications of antlerogenesis in deer. Caesar Kleberg Res. Prog. Wildlife Ecol., Ann. Rept. Texas Agric. Exp. Sta., pp. 32-33.

BROWN, W. M., AND J. M. INGLIS. 1982. Social organization and group dynamics of white-tailed deer on brush-free coastal prairie in Texas. P. 16, in Fifth Ann. Meeting Southeast Deer Study Group, Charleston, South Carolina, $24 \mathrm{pp}$.

BRYANT, F. C., AND B. MORRISON. 1985. Managing plains mule deer in Texas and eastern New Mexico. Manag. Notes, Range and Wildlife Dept., Texas Tech Univ., 7:1-5.

Bryant, L. D., AND C. Maser. 1982. Classification and distribution. Pp. 1-59, in Elk of North America ... (J. W. Thomas and D. E. Toweill, eds.), Stackpole Books, Harrisburg, Pennsylvania, $x \mathrm{x}+698 \mathrm{pp}$.

BUBENIK, G. A., AND R. D. BROWN. 1985. Influence of the pituitary-adrenal axis on the LH-RHinduced release of LH and testosterone in the male white-tailed deer. Caesar Kleberg Res. Prog. Wildlife Ecol., Ann. Rept. Texas Agric. Exp. Sta., pp. 38-39.

BUBENIK, G., AND R. BROWN. 1986a. Influence of the pituitary-adrenal axis on the LH-RH-induced release on $\mathrm{LH}$ and testosterone in the male white-tailed deer. Caesar Kleberg Res. Prog. Wildlife Ecol., Ann. Rept. Texas Agric. Exp. Sta., p. 28.

Bubenik, G., AND R. BROWN. 1986b. Reproductive cycle of axis deer. Caesar Kleberg Res. Prog. Wildlife Ecol., Ann. Rept. Texas Agric. Exp. Sta., p. 30.

BUBENIK, G. A., AND R. D. BROWN. 1987a. Effect of zylazine hydrochloride on plasma throxine and cortisol in white-tailed deer. Caesar Kleberg Res. Prog. Wildlife Ecol., Ann. Rept. Texas Agric. Exp. Sta., p. 31.

BUBENIK, G. A., AND R. D. BROWN. 1987b. Seasonal changes in plasma thyroxine and cortisol levels in axis deer. Caesar Kleberg Res. Prog. Wildlife Ecol., Ann. Rept. Texas Agric. Exp. Sta., p. 33.

Bubenik, G. A., AND R. D. Brown. 1987c. Response of LHRH and ACTH in axis deer. Caesar Kleberg Res. Prog. Wildlife Ecol., Ann. Rept. Texas Agric. Exp. Sta., pp. 33-34.

Butts, G. L., M. J. AnderegG, W. E. Armstrong, D. E. Harmel, C. W. Ramsey, and S. H. SOROLA. 1982. Food habits of five exotic ungulates of Kerr Wildlife Management area, Texas. Texas Parks and Wildlife Dept. Tech Ser., 30:1-47 (processed).

CARL, G. R., AND R. D. BROWN. 1984. Protein requirements of collared peccaries. Caesar Kleberg Res. Prog. Wildlife Ecol., Ann. Rept. Texas Agric. Exp. Sta., p. 17.

1985. Protein requirement of adult collared peccaries. J. Wildlife Manag., 49:351-355.

1986. Comparative digestive efficiency and feed intake of the collared peccary. Southwestern Nat., 31:79-85.

CAMPO, J. J., F. E. SPENCER, AND B. ORTEGO. 1987. White-tailed deer hunting with dogs in East Texas. Proc. Southeastern Assoc. Fish and Wildlife Agencies, 41:404-409. 
CANON, S. K., AND F. C. BRYANT. 1989a. Fawning habitat and adult habitat use of established pronghorn in western Texas. Research Highlights-1989, Noxious Brush and Weed Control, Texas Tech Univ., 20:33.

1989b. Fawning habitat characteristics and peri-natal and adult habitat use of transplanted pronghorn antelope. Welder Wildlife Foundation Biennial Rept., p. 10.

1990. Fawn survival and bed site characteristics of Trans Pecos pronghorn. Research Highlights-1990, Noxious Brush and Weed Control, Texas Tech Univ., 21:21.

CAPEN, D. E., T. F. KoHL, D. J. Hyde, AND C. A. DeYoung. 1986. An analysis of habitat preference by white-tailed deer on a South Texas ranch. Caesar Kleberg Res. Prog. Wildlife Ecol., Ann. Rept. Texas Agric. Exp. Sta.,p. 13.

Carr, S. M., S. W. Ballinger, J. N. Derr, L. H. Blankenship, and J. W. Bickham. 1986. Mitochondrial DNA analysis of hybridization between sympatric white-tailed deer and mule deer in West Texas. Proc. Nat. Acad. Sci., 83:9576-9580.

CARroll, B. K., D. H. ReID, AND R. W. JurRIES. 1987. Survivability and dispersal of adult whitetailed deer in southern central Texas. Pp. 9-10, in Tenth Ann. Meeting Southeast Deer Study Group, Gulf Shores, Alabama, 30 pp.

Chaney, A. H., AND C. Baskin. 1984. Grazing effects on wildlife use of oak mottes. Caesar Kleberg Res. Prog. Wildlife Ecol., Ann. Rept. Texas Agric. Exp. Sta., p. 8.

Chao, C. C., AND R. D. Brown. 1984a. Relationships between hormonal, climatic, and nutritional factors in South Texas white-tailed deer. Caesar Kleberg Res. Prog. Wildlife Ecol., Ann. Rept. Texas Agric. Exp. Sta., p. 16.

1984b. Measurement of parathyroid hormone in white-tailed deer. Caesar Kleberg Res. Prog. Wildlife Ecol., Ann. Rept. Texas Agric. Exp. Sta., pp. 34-35.

Chao, C. C., R. D. Brown, AND L. J. Deftos. 1984a. Parathyroid hormone, calcitonin, and alkaline phosphatase in relation to antler cycles in white-tailed deer. Caesar Kleberg Res. Prog. Wildlife Ecol., Ann. Rept. Texas Agric. Exp. Sta., p. 35.

1984b. Lack of an endocrine response to rompun on white-tailed deer. Caesar Kleberg Res. Prog. Wildlife Ecol., Ann. Rept. Texas Agric. Exp. Sta., p. 35.

1984c. Calcium metabolism during pregnancy and lactation in white-tailed deer. Caesar Kleberg Res. Prog. Wildlife Ecol., Ann. Rept. Texas Agric. Exp. Sta., p. 36.

COHEN, W. E., AND F. C. BRYANT. 1982. Deer movement and habitat response to short-duration grazing. Research Highlights-1982, Noxious Brush and Weed Control, Texas Tech Univ., 13:73.

1983. Deer movement and habitat response to short duration grazing. Research Highlights-1983, Noxious Brush and Weed Control, Texas Tech Univ., 14:55.

1984. Deer behavior response to short duration grazing. Research Highlights-1984, Noxious Brush and Weed Control, Texas Tech Univ., 15:40.

1985a. Deer movement and habitat response to short duration grazing in the Texas Coastal Bend. Research Highlights-1985, Noxious Brush and Weed Control, Texas Tech Univ., 16:35.

1985b. Short duration grazing effect on white-tailed deer home range and travel distance. Welder Wildlife Foundation Biennial Rept., p. 8.

COHEN, W. E., AND J. P. WORKMAN. 1987. Economic strategies for deer and quail production and management on Central and South Texas ranches. Welder Wildlife Found. Biennial Rept.,p. 10.

Cohen, W. E., D. L. Drawe, F. C. Bryant, and L. C. Bradley. 1989. Observations on whitetailed deer in habitat response to livestock grazing in South Texas. J. Range Manag., 42:361-365. 
Cohen, W. E., R. J. Reiner, F. C. Bryant, D. L. Drawe, and L. C. Bradley. 1989. Daytime activity of white-tailed deer in response to short-duration and continuous grazing. Southwestern Nat., 34:428-431.

CONNER, P., T. FUlbright, D. RANSOM, JR., AND F. S. GuTHERY. 1987a. Wildlife food response to herbicide application on disced rangeland. Caesar Kleberg Res. Prog. Wildlife Ecol., Ann. Rept. Texas Agric. Exp. Sta., p. 13.

- $1987 \mathrm{~b}$. Wildlife food plant response to seasonal discing on native South Texas rangeland. Caesar Kleberg Res. Prog. Wildlife Ecol., Ann. Rept. Texas Agric. Exp. Sta., p. 13.

- 1988. Wildlife food plant response to herbicide application on disced rangeland. Caesar Kleberg Res. Prog. Wildlife Ecol., Ann. Rept. Texas Agric. Exp. Sta., p. 31.

CoOK, R. L. 1981. Hunt management to accomplish harvest goals. Proc. 1981 Internat. Ranchers Roundup, Del Rio, Texas, pp. 376-381 (processed).

1984. Texas. Pp. 457-474, in White-tailed deer ecology and management (L. K. Halls, ed.), Wildlife Manag. Inst., Washington, D. C., and Stackpole Books, Harrisburg, Pennsylvania, xiii +870 pp.

CoOK, R. L., AND E. R. FuchS. 1989. Quality white-tailed deer management in central Texas. P. 8, in Twelfth Ann. Meeting Southeast Deer Study Group, Oklahoma City, 22 pp.

CoOK, R. L., G. R. FuchS, AND S. Demarais. 1987. Antlerless deer harvest effects on a whitetailed deer population. P. 19, in Tenth Ann. Meeting Southeast Deer Study Group, Gulf Shores, Alabama, $30 \mathrm{pp}$.

CORN, J. L., AND R. J. WARREN. 1982. Ecology of the collared peccary in Texas. Research Highlights-1982, Noxious Brush and Weed Control, Texas Tech Univ., 13:75.

1983. Physiological ecology of the collared peccary in South Texas. Research Highlights-1983, Noxious Brush and Weed Control, Texas Tech Univ., 14:53-54.

1985a. Seasonal food habits of the collared peccary in South Texas. J. Mamm., 66:155159.

1985b. Seasonal variation in nutritional indices of collared peccaries in South Texas. J. Wildlife Manag., 49:57-65.

Corn, J. L., D. M. Kavanaugh, D. A. Osborn, S. Demarais, D. M. Miller, and V. F. Nettles. 1990. Survey for diseases and parasites in exotic ruminants in Texas. Research Highlights-1990, Noxious Brush and Weed Control, Texas Tech Univ., 21:20.

Coughlin, S., C. A. Deyoung, S. L. Beasom, And J. HefFlefinger. 1987. Effects of heavy harvest on South Texas deer populations. Caesar Kleberg Res. Prog. Wildlife Ecol., Ann. Rept. Texas Agric. Exp. Sta., pp. 21-22.

1988. Effects of heavy harvest on South Texas deer populations. Caesar Kleberg Res. Prog. Wildlife Ecol., Ann. Rept. Texas Agric. Exp. Sta., p. 13.

Coughlin, S., C. A. Deyoung, S. L. Beasom, J. Heffelfinger, J. Sullivan, and M. HellickSON. 1989. Effects of heavy harvest on South Texas deer populations. Caesar Kleberg Res. Prog. Wildlife Ecol., Ann. Rept. Texas Agric. Exp. Sta., p. 1.

Crenshaw, D. B. 1982. Antler quality prediction by testosterone radioimmunoassay after GnRH challenge in immature white-tailed bucks. Caesar Kleberg Res. Prog. Wildlife Ecol., Ann. Rept. Texas Agric. Exp. Sta., pp. 19-21.

1983. Antler quality prediction by testosterone radioimmunoassay after GnRH challenge in immature white-tailed bucks. Caesar Kleberg Res. Prog. Wildlife Ecol., Ann. Rept. Texas Agric. Exp. Sta., pp. 8-9.

DAhABAN, Z., R. D. BROWN, AND A. GARZA. 1987. Fecal indices of dietary quality of white-tailed deer in South Texas. Caesar Kleberg Res. Prog. Wildlife Ecol., Ann. Rept. Texas Agric. Exp. Sta., p. 31. 
DAILEY, T., R. Brown, AND T. MCCALL. 1986. Nutritional habitat assessment of South Texas rangeland for the carrying capacity of white-tailed deer. Caesar Kleberg Res. Prog. Wildlife Ecol., Ann. Rept. Texas Agric. Exp. Sta., p. 16.

DASMAN, W. 1981. Deer range-improvement and management. McFarland \& Co., Inc., Jefferson, North Carolina, $168 \mathrm{pp}$.

DAvis, D. S. 1984. Oral anthrax vaccination in white-tailed deer. Caesar Kleberg Res. Prog. Wildlife Ecol., Ann. Rept. Texas Agric. Exp. Sta., p. 19.

DAvIS, D. S., AND R. G. WARD. 1984. Winter die-off of nilgai antelope along the South Texas Coast. Caesar Kleberg Res. Prog. Wildlife Ecol., Ann. Rept. Texas Agric. Exp. Sta., p. 19.

Davis, D. S., AND J. D. Williams. 1984. Phenotypic genetic selection for quality white-tailed deer. Caesar Kleberg Res. Prog. Wildlife Ecol., Ann. Rept. Texas Agric. Exp. Sta., p. 21.

1985. Genetic selection for quality white-tailed deer. Caesar Kleberg Res. Prog. Wildlife Ecol., Ann. Rept. Texas Agric. Exp. Sta., pp. 23-24.

DAVIS, E. 1984a. Basic white-tailed deer biology and habitat requirements. Pp. 52-55, in Proc. Brush Country Wildlife Symp. Texas Agric. Ext. Serv., College Station, 72 pp.

1984b. How to manage deer habitat: South Texas. Proc. 1984 Internat. Ranchers Roundup, San Angelo, Texas, pp. 311-315 (processed).

1990. Deer management in the South Texas Plains. Texas Parks Wildlife Dept., FA Rept. Ser., 27:1-32.

Demarais, S. 1989a. Marketing wildlife: a job and an adventure. Texas Safari Quart., 3(1):6-8, 48.

1989b. The project: spring season. J. Texas Trophy Hunters, pp. 2-5, (July-August).

1989c. The project: summer stress. J. Texas Trophy Hunters, pp. 12-14, (SeptemberOctober).

1989d. Population dynamics of desert mule deer in the Trans Pecos Region. Research Highlights-1989, Noxious Brush and Weed Control, Texas Tech Univ., 20:31.

1989e. Cost effectiveness of supplementally feeding white-tailed deer in the Edward's Plateau. Research Highlights-1989, Noxious Brush and Weed Control, Texas Tech Univ., 20:32.

Demarais, S., AND D. A. BarnetT. 1984. Orphaning effects on white-tailed deer fawns in South Texas. Research Highlights-1984, Noxious Brush and Weed Control, Texas Tech Univ., 15:40.

Demarais, S., AND B . LAmBERT. 1990. Cost-effectiveness of supplementally feeding whitetailed deer in the Edwards Plateau region. Research Highlights-1990, Noxious Brush and Weed Control, Texas Tech Univ., 21:19.

Demarais, S., AND D. A. OsBoRn. 1988. Exotic big game in Texas: status of our knowledge. Proc. 1988 Internat. Ranchers Roundup, San Antonio, Texas, pp. 138-145 (processed).

Demarais, S., AND R. E. ZAiglin. 1986. Home range and survival of mature male white-tailed deer in South Texas. Research Highlights-1986, Texas Tech Univ., 17:34-35.

1987. Home range and survival of mature male white-tailed deer in South Texas. Research Highlights-1987, Noxious Brush and Weed Control, Texas Tech Univ., 18:33.

1988. Doe harvest effects. Rangelands, 10:220-223.

Demarais, S., AND B. Zaiglin. 1987. The effect of doe harvest on white-tailed deer populations. Proc. 1987 Internat. Ranchers Roundup, Kerrville, Texas, pp. 120-124 (processed).

DemaraIS, S., D. A. OSBORN, AND J. J. JACKLEY. 1990. Exotic big game: a controversial resource. Rangelands, 12:121-125.

Demarais, S., M. L. Richardson, and S. L. Beasom. 1984. Orphaning effects on white-tailed deer fawns in South Texas. Caesar Kleberg Res. Prog. Wildlife Ecol., Ann. Rept. Texas Agric. Exp. Sta., pp. 21-22. 
Demarais, S., R. E. Zaiglin, AND D. A. Barnetr. 1986. Orphaning effects on white-tailed deer fawns in South Texas. Research Highlights-1986, Noxious Brush and Weed Control, Texas Tech Univ., 17:32-33.

1987a. The effect of orphaning on survival and home range of white-tailed deer fawns. P. 20, in Tenth Ann. Meeting Southeast Deer Study Group, Gulf Shores, Alabama, 30 pp.

1987b. Orphaning effects on white-tailed deer fawns in South Texas. Research Highlights-1987, Noxious Brush and Weed Control, Texas Tech Univ., 18:34.

1988. Physical development of orphaned white-tailed deer fawns in southern Texas. J. Range Manag., 41:340-342.

Demarais, S., R. E. Zaiglin, And K. Etling. 1989. Blueprinting big bucks. Outdoor Life, 1984(1):61-63, 108-113.

Demarais, S., R. E. Zaiglin, AND M. J. Pollock. 1988. Home range and survival of mature male white-tailed deer in South Texas. Pp. 25-26, in Eleventh Ann. Meeting Southeast Deer Study Group, Paducah, Kentucky, 26 pp.

Demarais, S., R. E. Zaiglin, M. J. Pollock, and D. G. Whittaker. 1989. Environmental effects on activity patterns of mature white-tailed deer. Pp. 20-21, in Twelfth Ann. Meeting Southeast Deer Study Group, Oklahoma City, 22 up.

Delmonte, B. D., AND H. G. KothmanN. 1983. Evaluation of Texas antelope transplants. Proc. Antelope State Workshop, 11:146-150.

DELIBERTO, T. J., AND J. A. PFISTER. 1987. A stable source for post-mortem sampling of urea nitrogen in white-tailed deer. Pp. 13-14, in Tenth Ann. Meeting Southeast Deer Study Group, Gulf Shores, Alabama, $30 \mathrm{pp}$.

Deliberto, T. J., J. A. Pfister, AND S. Demarais. 1986. A stable source for postmortem sampling of urea nitrogen in white-tailed deer. Research Highlights-1986, Noxious Brush and Weed Control, Texas Tech Univ., 17:33.

Deliberto, T. J., J. A. Pfister, S. Demarais, and U. S. Seal. 1988. Urea nitrogen in serum and vitreous humor of white-tailed deer. J. Wildlife Manag., 52:599-601.

Deliberto, T. J., G. V. Breede, J. A. Pfister, S. Demarais. AND F. C. Bryant. 1987. Energy and nitrogen-limiting seasons for white-tailed deer in the midwest oak/hickory forest. Research Highlights—1987, Noxious Brush and Weed Control, Texas Tech Univ., 18:31.

Deyoung, C. A. 1984. Accuracy of helicopter surveys of deer in South Texas. Caesar Kleberg Res. Prog. Wildlife Ecol., Ann. Rept. Texas Agric. Exp. Sta., p. 22.

1985a. Accuracy of helicopter surveys of deer in South Texas. Wildlife Soc. Bull., 13:149-153.

1985b. Factors limiting quality buck production in South Texas. Caesar Kleberg Res. Prog. Wildlife Ecol., Ann. Rept. Texas Agric. Exp. Sta., p. 25.

1987a. A pilot study of the genetic implications to deer of long-term confinement within a deer-proof fence. Caesar Kleberg Res. Prog. Wildlife Ecol., Ann. Rept. Texas Agric. Exp. Sta., p. 24.

1987b. Evaluation of a net gun for capturing deer in South Texas. Caesar Kleberg Res. Prog. Wildlife Ecol., Ann. Rept. Texas Agric. Exp. Sta., p. 32.

1987c. Evaluation of the effects of removing an incisor tooth from live deer. Caesar Kleberg Res. Prog. Wildlife Ecol., Ann. Rept. Texas Agric. Exp. Sta., p. 31.

1987d. White-tailed buck mortality in South Texas. Proc. 1987 Internat. Ranchers Roundup, Kerrville, Texas, pp. 108-110 (processed).

1987e. Factors limiting quality buck management: natural mortality. Pp. 8-9, in Tenth Ann. Meeting Southeast Deer Study Group, Gulf Shores, Alabama, $30 \mathrm{pp}$.

1988a. Comparison of net-gun and drive-net capture for white-tailed deer. Wildlife Soc. Bull., 16:318-320. 
1988b. Inefficiency in trophy buck harvest. Caesar Kleberg Res. Prog. Wildlife Ecol., Ann. Rept. Texas Agric. Exp. Sta., p. 12.

1988c. Approximating age-specific mortality rates in South Texas bucks. Caesar Kleberg Res. Prog. Wildlife Ecol., Ann. Rept. Texas Agric. Exp. Sta., pp. 12-13.

1988d. A pilot study of the genetic implications to deer of long-term confinement within a deer-proof fence. Caesar Kleberg Res. Prog. Wildlife Ecol., Ann. Rept. Texas Agric. Exp. Sta., p. 16.

1988e. Evaluation of 2 methods for aging live deer. Caesar Kleberg Res. Prog. Wildlife Ecol., Ann. Rept. Texas Agric. Exp. Sta., p. 45.

1988f. Evaluation of a netgun for capturing deer in South Texas. Pp. 13-14, in Eleventh Ann. Meeting Southeast Deer Study Group, Paducah, Kentucky, 26 pp.

1989a. Mortality of adult male white-tailed deer in South Texas. J. Wildlife Manag., 53:513-518.

1989b. Aging live white-tailed deer on southern ranges. J. Wildlife Manag., 53:519-523.

1989c. A pilot study of the genetic implications to deer of long term confinement within a deer proof fence. Caesar Kleberg Res. Prog. Wildlife Ecol., Ann. Rept. Texas Agric. Exp. Sta., p. 3.

$1989 d$. Trends in the quality of successive antler bucks in free ranging deer. Pp. 11-12, in Eleventh Ann. Meeting Southeast Deer Study Group, Paducah, Kentucky, 26 pp.

1990a. Inefficiency in trophy white-tailed deer harvest. Wildlife Soc. Bull., 18:7-12.

$1990 \mathrm{~b}$. Evaluation of bias in antler measurements of harvested white-tailed deer on a South Texas ranch. Texas J. Agric. Nat. Res., 3:24-25.

Deyoung, C. A., AND L. J. BAREISS. 1986. Factors limiting quality buck production in South Texas. Caesar Kleberg Res. Prog. Wildlife Ecol., Ann. Rept. Texas Agric. Exp. Sta., p. 20.

DeYoung, C. A., AND C. E. DAvis. 1982. An analysis of helicopter-assisted counts for censusing white-tailed deer in South Texas. Pp. 18-19, in Fifth Ann. Meeting Southeast Deer Study Group, Charleston, South Carolina, $24 \mathrm{pp}$.

Deyoung, C. A., AND R. J. Mouton. 1981. Possibilities for field recognition of white-tailed deer age groups based on antler size. Caesar Kleberg Res. Prog. Wildlife Ecol., Ann. Rept. Texas Agric. Exp. Sta., pp. 19-20.

1982. Possibilities for field recognition of white-tailed deer age groups based on antler size. Caesar Kleberg Res. Prog. Wildlife Ecol., Ann. Rept. Texas Agric. Exp. Sta., p. 18.

DEYOUNG, C. A., AND P. SCHULZ. 1987a. Factors limiting quality buck production in South Texas. Caesar Kleberg Res. Prog. Wildlife Ecol., Ann. Rept. Texas Agric. Exp. Sta.,p. 19.

1987b. Mortality rates and causes in white-tailed bucks on 2 South Texas ranches. Caesar Kleberg Res. Prog. Wildlife Ecol., Ann. Rept. Texas Agric. Exp. Sta., p. 19.

DeYoung, C. A., AND D. Woods. 1985. Effects of short duration grazing on range condition and white-tailed deer. Caesar Kleberg Res. Prog. Wildlife Ecol., Ann. Rept. Texas Agric. Exp. Sta., p. 9.

Deyoung, C. A., T. F. Kohl, And A. Garza. 1985. Diet analysis of white-tailed deer and cattle under short duration and continuous grazing. Caesar Kleberg Res. Prog. Wildlife Ecol., Ann. Rept. Texas Agric. Exp. Sta., p. 6.

Deyoung, C. A., S. L. Beasom, S. Coughlin, AND J. Hefrelfinger. 1988. Evaluation of bias in the proportion of fawns sighted during fall helicopter surveys. Caesar Kleberg Res. Prog. Wildlife Ecol., Ann. Rept. Texas Agric. Exp. Sta., p. 17.

1989. Evaluation of fawns sighted during fall helicopter surveys. Caesar Kleberg Res. Prog. Wildlife Ecol., Ann. Rept. Texas Agric. Exp. Sta., p. 4. 
Deyoung, C. A., S. L. Beasom, S. Coughlin, ANDP. Schulz. 1987. Evaluation of bias in the proportion of fawns sighted during fall helicopter surveys. Caesar Kleberg Res. Prog. Wildlife Ecol., Ann. Rept. Texas Agric. Exp. Sta., p. 18.

Deyoung, C. A., S. Coughlin, S. L. Beasom, AND J. HefFelfinger. 1987. Is deer harvest a compensatory or additive mortality factor in South Texas? Caesar Kleberg Res. Prog. Wildlife Ecol., Ann. Rept. Texas Agric. Exp. Sta., p. 22.

1988a. Is deer harvest a compensatory or additive mortality factor? Pp. 1-2, in Eleventh Ann. Meeting Southeast Deer Study Group, Paducah, Kentucky, 26 pp.

$1988 b$. Effects of heavy harvest on South Texas deer populations. Pp. 4-5, in Eleventh Ann. Meeting Southeast Deer Study Group, Paducah, Kentucky, 26 pp.

$1988 c$. Is deer havest a compensatory of additive mortality factor in South Texas? Caesar Kleberg Res. Prog. Wildlife Ecol., Ann. Rept. Texas Agric. Exp. Sta., p. 13.

Deyoung, C. A., J. R. Heffelfinger, S. P. Coughlin, And S. L. Beasom. 1988a. Accuracy of track counts to estimate white-tailed deer abundance. Proc. Southeastern Assoc. Fish Wildlife Agencies, 42:464-469.

1988b. Accuracy of track counts as an estimator of white-tailed deer abundance. Caesar Kleberg Res. Prog. Wildlife Ecol., Ann. Rept. Texas Agric. Exp. Sta., p. 16.

Deyoung, C. A., F. S. Guthrey, S. L. Beasom, S. Coughlin, And J. Heffelfinger. 1988. Reducing bias in helicopter surveys of deer. Caesar Kleberg Res. Prog. Wildlife Ecol., Ann. Rept. Texas Agric. Exp. Sta., p. 16.

$1989 a$. Improving estimates of white-tailed deer abundance from helicopter surveys. Wildlife Soc. Bull., 17:275-279.

$1989 \mathrm{~b}$. Reducing bias in helicopter surveys of white-tailed deer abundance. P. 17, in Twelfth Ann. Meeting Southeast Deer Study Group, Oklahoma City, 22 pp.

Deyoung, C. A., F. S. Guthery, S. L. Beasom, S. Coughlin, ANd P. Schulz. 1987. Evaluation of line transect estimates for improving accuracy and precision of helicopter surveys of deer. Caesar Kleberg Res. Prog. Wildlife Ecol., Ann. Rept. Texas Agric. Exp. Sta., p. 19.

Deyoung, C. A., K. J. Hyde, T. Kohl, A. GarZA, And S. L. Beasom. 1987. Deer relative abundance and fawn production in a short duration vs. continuously grazed area. Caesar Kleberg Res. Prog. Wildlife Ecol., Ann. Rept. Texas Agric. Exp. Sta., p. 6.

Deyoung, C. A., S. L. Beasom, J. Heffelfinger, S. Coughlin, M. Hellickson, and J. SulliVAN. 1989. Winter fawn mortality in 2 South Texas deer populations. Caesar Kleberg Res. Prog. Wildlife Ecol., Ann. Rept. Texas Agric. Exp. Sta., p. 3.

1990. Winter fawn mortality in South Texas deer populations. P. 16, in Thirteenth Ann. Meeting Southeast Deer Study Group, Pipestem, West Virginia, 26 pp.

Deyoung, C. A., S. L. Beasom, J. Heffelfinger, S. Coughlin, J. B. Sullivan, And M. W. HelLICKSON. 1990. Evaluating responses of South Texas deer to harvest and coyote reduction. Caesar Kleberg Res. Prog. Wildlife Ecol., Ann. Rept. Texas Agric. Exp. Sta., p. l.

Deyoung, C. A., S. Coughlin, S. L. Beasom, J. Heffelfinger, J. Sullivan, and M. HellickSON. 1989. Is deer harvest a compensatory or additive mortality factor in South Texas? Caesar Kleberg Res. Prog. Wildlife Ecol., Ann. Rept. Texas Agric. Exp. Sta., p. 2.

DROLL, J. C., AND B. HigGinBothan. 1988. Evaluation of supplemental forages for white-tailed deer in eastern Texas. Pp. 19-20, in Eleventh Ann. Meeting Southeast Deer Study Group, Paducah, Kentucky, 26 pp.

EEMS, D. V. D., AND R. D. BROWN. 1984. Biochemical investigation of bone metabolism in male white-tailed deer. Caesar Kleberg Res. Prog. Wildlife Ecol., Ann. Rept. Texas Agric. Exp. Sta., pp. 36-37.

1985a. Biomedical implications of antler growth in deer. Caesar Kleberg Res. Prog. Wildlife Ecol., Ann. Rept. Texas Agric. Exp. Sta., p. 40. 
$1985 \mathrm{~b}$. The effect of xylazine, ketamine, caffeine, and yohimbine on feed intake in whitetailed deer. Caesar Kleberg Res. Prog. Wildlife Ecol., Ann. Rept. Texas Agric. Exp. Sta., p. 40.

- 1987. Urinary C-AMP and GLA associated with antler growth periods in white-tailed deer. Caesar Kleberg Res. Prog. Wildlife Ecol., Ann. Rept. Texas Agric. Exp. Sta., p. 35.

ELLSWORTH, D. L., N. J. SILVY, AND J. W. BICKHAM. 1989. Evolutionary genetics of white-tailed deer in the southeastern United States inferred from allozymic and mitochondrial DNA analyses. Welder Wildlife Found. Biennial Rept., p. 9.

EVERITT, J. H., AND C. L. GoNZALES. 1981. Seasonal nutrient content in food plants of whitetailed deer on the South Texas plains. J. Range Manag., 34:506-510.

EVeritT, J. H., C. L. Gonzales, M. A. Alaniz, AND V. G. Latigo. 1981. Food habits of the collared peccary on South Texas rangelands. J. Range Manag., 34:141-144.

Fafarman, K. R., And C. A. Deyoung. 1986. Evaluation of spotlight counts of deer in South Texas. Wildlife Soc. Bull., 14:180-185.

FEATHER, C. L., AND T. E. FULBRIGHT. 1989. Palatibility and yield of winter food plants for whitetailed deer. Caesar Kleberg Res. Prog. Wildlife Ecol., Ann. Rept. Texas Agric. Exp. Sta., pp. 21-22.

- 1990. Palatibility and yield of summer food plants for white-tailed deer. Caesar Kleberg Res. Prog. Wildlife Ecol., Ann. Rept. Texas Agric. Exp. Sta., pp. 11-12.

Feldhamer, G. A., K. C. Farris-Renner, And C. M. Barker. 1988. Dama dama. Mamm. Species, 317:1-8.

Fleming, K. M. 1983a. Managing white-tailed deer on an East Texas hunting club. P. 17, in Sixth Ann. Meeting Southeast Deer Study Group, Athens, Georgia, 27 pp.

1983b. Quality white-tailed deer management on an East Texas hunting club. Proc. Southeastern Assoc. Fish and Wildlife Agencies, 37:118-126.

1987a. Long-term effects of mechanical treatment on white-tailed deer browse. Wildlife Soc. Bull., 15:560-564.

1987b. Effects of roller chopping rangeland on use by white-tailed deer and bobwhites. Caesar Kleberg Res. Prog. Wildlife Ecol., Ann. Rept. Texas Agric. Exp. Sta., p. 3.

FULBRIGHT, T., AND S. BEASOM. 1987a. Effects of roller chopping on nutritional status of whitetailed deer. Caesar Kleberg Res. Prog. Wildlife Ecol., Ann. Rept. Texas Agric. Exp. Sta., pp. 2-3.

FULBRight, T., AND D. CASSELS. 1986. Effects of discing on brush species composition. Caesar Kleberg Res. Prog. Wildlife Ecol., Ann. Rept. Texas Agric. Exp. Sta., pp. 7-8.

FULBRIGHT, T., AND A.GARZA. 1985. Effects of tebuthiuron application on forage production and deer habitat on rangeland with dense live oak. Caesar Kleberg Res. Prog. Wildlife Ecol., Ann. Rept. Texas Agric. Exp. Sta., p. 4.

1989. Effects of treating live oak with tebuthiuron on white-tailed deer diets. Caesar Kleberg Res. Prog. Wildlife Ecol., Ann. Rept. Texas Agric. Exp. Sta., p. 11.

Fulbright, T. E., L. W. Brothers, E. Montemayor, and B. J. SChat. 1989. Long-term effects of heavy discing on white-tailed deer browse. Caesar Kleberg Res. Prog. Wildlife Ecol., Ann. Rept. Texas Agric. Exp. Sta., p. 12.

Gallagher, J. F., AND L. H. BlankEnShip. 1987. Fecal indices of nutrient intake for the whitetailed deer. Welder Wildlife Found. Biennial Rept., p. 11.

GALLAGHER, J. F., AND L. W. VARNER. 1989. Fecal indices of nutrient intake for white-tailed deer. Welder Wildlife Found. Biennial Rept., p. 11.

Gallagher, J. F., L. W. Varner, AND W. E. Grant. 1984. Nutrition of the collared peccary in South Texas. J. Wildlife Mang., 48:749-761. 
GALlaGHeR, J. F., R. L. LOCHMILLER, AND W. E. GRANT. 1985. Immobilization of collared peccaries with ketamine hydrochloride. J. Wildlife Manag., 49:356-357.

GARZA, A. 1986. Use of fecal indices to estimate trends in diet quality of white-tailed deer. Caesar Kleberg Res. Prog. Wildlife Ecol., Ann. Rept. Texas Agric. Exp. Sta., p. 30.

1988. Mineral status of white-tailed deer in South Texas. Caesar Kleberg Res. Prog. Wildlife Ecol., Ann. Rept. Texas Agric. Exp. Sta., p. 46.

GARZA, A., AND T. FULBRIGHT. 1986. Effects of tebuthiuron application on forage production and deer habitat on rangeland with dense live oak. Caesar Kleberg Res. Prog. Wildlife Ecol., Ann. Rept. Texas Agric. Exp. Sta., p. 7.

1987. Effects of tebuthiuron application on forage and deer habitat on rangeland with dense live oak. Caesar Kleberg Res. Prog. Wildlife Ecol., Ann. Rept. Texas Agric. Exp. Sta., p. 1.

GEE, K. L. 1982. Home ranging and activity center establishment by white-tailed deer on brushfree Texas Coastal prairie. P. 17, in Fifth Ann. Meeting Southeast Deer Study Group, Charleston, South Carolina, $24 \mathrm{pp}$.

GLOVER, M. K., AND J. R. CONNER. 1988. A model for selecting optimal combinations of livestock and deer lease-hunting enterprises. Wildlife Soc. Bull., 16:158-163.

Goodrum, W.D., J. C. Kroll, D. R. DieTZ, AND D. STANLEY. 1989. Development of an optimum sustained yield management system for the southern mixed pine-hardwood forest. Pp. 8-9, in Twelfth Ann. Meeting Southeast Deer Study Group, Oklahoma City, 22 pp.

Gore, H. G. 1983. The spike buck paradox of Texas white-tailed deer management. Pp. 355-364, in Antler development in Cervidae (R. D. Brown, ed.), Proc. First Internat. Symp. Caesar Kleberg Wildlife Res. Ins., Kingsville, xiii + 1-480 pp.

1984. Potential impact of liberalized regulations to promote spike buck harvest in Texas. P. 16, in Seventh Ann. Meeting Southeast Deer Study Group, Little Rock, Arkansas, 19 pp.

1988. Benefits from deer management. Proc. 1988 Internat. Ranchers Roundup, San Antonio, pp. 128-137 (processed).

Gore, H. G., W. F. HARWELl, M. D. HobSON, AND W. J. Williams. 1985. Buck permits as a management tool in South Texas. Pp. 149-163, in Game harvest management (S. L. Beasom and S. F. Robertson, eds.), Caesar Kleberg Wildlife Res. Inst., Texas A\&I Univ., Kingsville, $x v i+374 \mathrm{pp}$.

Grant, D. L. 1981. Electric deer proof fence. Caesar Kleberg Res. Prog. Wildlife Ecol., Ann. Rept. Texas Agric. Exp. Sta., pp. 34-35.

GRAY, G. G., AND D. SIMPSON. 1982. Group dynamics of free-ranging barbary sheep in Texas. J. Wildlife Manag., 46:1096-1100.

1983. Population characteristics of free-ranging barbary sheep in Texas. J. Wildlife Manag., 47:954-963.

Green, W. E., W. E. Grant, and E. Davis. 1985. Effects of hunting on javelina in South Texas. Wildlife Soc. Bull., 13:153-157.

Guthrey, F. S. 1990. A new multiple capture population estimator. Caesar Kleberg Res. Prog. Wildlife Ecol., Ann. Rept. Texas Agric. Exp. Sta., pp. 26-27.

GuYnN, D. C., JR. 1981. How to manage deer populations. Proc. 1981 Internat. Ranchers Roundup, Del Rio, Texas, pp. 367-375 (processed).

1982. Deer census using spotlight and Hahn lines. Proc. 1982 Internat. Ranchers Roundup, Del Rio, Texas, pp. 324-331 (processed).

1983. Interpreting harvest records. Proc. 1983 Internat. Ranchers Roundup, San Angelo, Texas, pp. 418-426 (processed). 
GuYNN, D. C., JR., AND R. J. HAmiLton. 1986. The effects of adult sex ratio on reproduction in white-tailed deer. Proc. 1986 Internat. Ranchers Roundup, Kerrville, Texas, pp. 233240 (processed).

GuYnN, D. C., JR., R. L. MaRChinton, AND R. J. HAMilton. 1989. Consideration for harvest of spike-antlered white-tailed deer. Pp. 10-11, in Twelfth Ann. Meeting Southeast Deer Study Group, Oklahoma City, 22 pp.

HaLLS, L. K. 1980. Characteristics of deer browse plants growing in East Texas forests. Pp. 2122, in Third Ann. Meeting Southeast Deer Study Group, Nacogdoches, Texas, 27 pp.

1981 $a$. White-tailed deer. Pp. 12-15, in A forester's guide to observing wildlife use of a forest habitat in the South (N. A. Byrd, ed.), USDA Forest Serv., Southeastern Area, Atlanta, Georgia, Forest Rept., SA-FR 15:1-37.

1981b. A case history of two deer enclosures in East Texas. Pp. 9-10, in Fourth Ann. Meeting Southeast Deer Study Group, Tallahassee, Florida, 20 pp.

(ed.). 1984. White-tailed deer ecology and management. Wildlife Manag. Inst., Washington, D. C., and Stackpole Books, Harrisburg, Pennsylvania, xxiii +870 pp., 16 pls. (Book with 46 chapters, many of which make reference to Texas; three are cited separately in this bibliography.)

HALLS, L. K., AND C. E. BOYD. 1982. Influence of managed pine stands and mixed pine-hardwood stands on well being of deer. USDA Forest Serv. Res. Paper, SO-183:1-18.

HaNNON, P. G., AND W. E. GRANT. 1988. Biochemistry and hematology of collard peccaries (Tayassu tajacu) during postweaning growth. J. Mamm., 69:413-417.

Hanselka, C. W. 1984. Key food plants for deer-West Texas. Proc. 1984 Internat. Ranchers Roundup, San Angelo, Texas, pp. 292-301 (processed).

Hannon, P. G., R. M. Robinson, D. Synatzske, ANd W. E. Grant. 1987. Evidence against existence of the preorbital gland in collared peccaries (Tayassu tajacu). J. Mamm. 68:682-683.

HARMEL, D. E. 1983. Effects of genetics on antler quality and body size in white-tailed deer. Pp. 339-348, in Antler development in Cervidae (R. D. Brown, ed.), Proc. First Internat. Symp. Caesar Kleberg Wildlife Res. Ins., Kingsville, xiii + 480 pp.

1984. Spike bucks - nutritional or genetic. Proc. 1984 Internat. Ranchers Roundup, San Angelo, Texas, pp. 353-363 (processed).

HARMEL, D. E., AND W. E. ARMSTRONG. 1990. Use of a "deer crush" for handling captive whitetailed deer. P. 21, in Thirteenth Ann. Meeting Southeast Deer Study Group, Pipestem, West Virginia, $26 \mathrm{pp}$.

Harmel, D. E., W. E. ARmstrong, AND J. D. Williams. 1989. Comparison of antler characteristics for spike versus fork antlered deer at 1.5 through 6.5 years of age. P. 12, in Twelfth Ann. Meeting Southeast Deer Study Group, Oklahoma City, 22 pp.

Harmel, D. E., J. D. Williams, AND W. E. ARmStrong. 1989. Effects of genetics and nutrition on antler development and body size of white-tailed deer. Texas Parks Wildlife Dept., FA Rept. Ser., 26:1-55 (processed).

HaRWELL, F. 1989. Management recommendations for white-tailed deer on private lands and resultant harvest. P. 7, in Twelfth Ann. Meeting Southeast Deer Study Group, Oklahoma City, 22 pp.

HARWEll, F., R. L. COOK, AND J. C. BARRon. 1981. The spotlight count method for surveying white-tailed deer in Texas. P. 12, in Fourth Ann. Meeting Southeast Deer Study Group. Tallahasse, Florida, $20 \mathrm{pp}$.

Harwell, F., D. Harmel, and J. Perkins. 1985. A tale of two deer herds. Texas Parks Wildlife, 43(12):36-40.

HeFFELFINGER, J. R., AND S. L. BEASOM. 1989. Effects of intensive coyote control on post-rut mortality of male white-tailed deer. Welder Wildlife Found. Biennial Rept., pp. 11. 
Heffelfinger, J. R., S. Beasom, S. Coughlin, AND C. A. Deyoung. 1988. Effects of intensive coyote control on post-rut mortality of male white-tailed deer. P. 25, in Eleventh Ann. Meeting Southeast Deer Study Group, Paducah, Kentucky, 26 pp.

Heffelfinger, J., S. Coughlin, S. L. Beasom, and C. A. Deyoung. 1987. Effects of intensive coyote control on the post-rut mortality of adult buck white-tailed deer. Caesar Kleberg Res. Prog. Wildlife Ecol., Ann. Rept. Texas Agric. Exp. Sta., p. 20.

1988. Effects of intensive coyote control on post-rut mortality of buck white-tailed deer. Caesar Kleberg Res. Prog. Wildlife Ecol., Ann. Rept. Texas Agric. Exp. Sta., p. 14.

Heffelfinger, J., S. Coughlin, S. L. Beasom, C. A. DeYoung, M. Hellickson, and J. Sullivan. 1989. Effects of intensive coyote control on post-rut mortality of buck white-tailed deer. Caesar Kleberg Res. Prog. Wildlife Ecol., Ann. Rept. Texas Agric. Exp. Sta., p. 2.

Hellgren, E. C. 1989. Phophorus nutrition in white-tailed deer in South Texas. Caesar Kleberg Res. Prog. Wildlife Ecol., Ann. Rept. Texas Agric. Exp. Sta., p. 35.

Hellgren, E. C., R. L. Lochmiller, and W. E. Grant. 1984. Demographic, morphologic and reproductive status of a herd of collared peccaries (Tayassu tajacu) in south Texas. American Midland Nat., 112:402-407.

1985. Pregnancy diagnosis in the collared peccary by ultrasonic amplitude-depth analysis. J. Wildlife Manag., 49:71-73.

Hellgren, E. C., B. Grasman, AND L. J. Deftos. 1990. Effect of dietary phosphorus on antler growth and physiology in adult white-tailed deer. Caesar Kleberg Res. Prog. Wildlife Ecol., Ann. Rept. Texas Agric. Exp. Sta.,p. 11.

Hellgren, E. C., D. R. SynatzSKe, AND J. R. PACKARD. 1990. Demographic and condition characteristics of a harvested javelina population in South Texas. Caesar Kleberg Res. Prog. Wildlife Ecol., Ann. Rept. Texas Agric. Exp. Sta., pp. 2-3.

Hellgren, E. C., R. L. Lochmiller, M. A. Amoss, JR., AND W. E. Grant. 1985. Serum progesterone, estradiol-17B, and glucocorticoids in the collared peccary during gestation and lactation as influenced by dietary protein and energy. Gen. Comp. Endocrin., 59:358369.

Hellgren, E. C., R. L. Lochmiller, M. S. Amoss, JR., S. W. Seager, and W. E. GRant. 1985. P. 51 , in Reproductive biology of the male collared peccary. First Peccary Workshop, Univ. Arizona, Tucson, $82+8$ unnumbered pp.

Hellgren, E. C., R. L. Lochmiller, M. S. Amoss, JR., S. W. Seager, S. J. Magyar, K. P. CosCARELLI, AND W. E. GRANT. 1989. Seasonal variation in serum testosterone, testicular measurements, and seasonal characteristics in the collared peccary (Tayassu tajacu). J. Reprod. Fert., 85:677-686.

Hellickson, M. W., AND C. A. Deyoung. 1990. Predicting carrying capacity for white-tailed deer using grazeable aboveground biomass. Caesar Kleberg Res. Prog. Wildlife Ecol., Ann. Rept. Texas Agric. Exp. Sta., pp. 10-11.

HENKE, S. E., S. DemaraIS, AND J. PFISTER. 1987a. Digestive capacity as a factor in competition among white-tailed deer and exotic ruminants. P. 16, in Tenth Ann. Meeting Southeast Deer Study Group, Gulf Shores, Alabama, 30 pp.

$1987 \mathrm{~b}$. Is digestive capacity a factor in competition among white-tailed deer and exotic ruminants? Research Highlights-1987, Noxious Brush and Weed Control, Texas Tech Univ., 18:30.

1988. Digestive capacity and diet selectivity of white-tailed deer and exotic ruminants. J. Wildlife Manag., 52:595-598.

HigGinBothan, B., AND J. C. KROLL. 1989. Warm and cool season food plot strategies for southern white-tails: a two-year progress report. Pp. 18-19, in Twelfth Ann. Meeting Southeast Deer Study Group. Oklahoma City, 22 pp. 
HIRTH, D. H. 1985. Mother-young behavior in white-tailed deer, Odocoileus virginianus. Southwestern Nat., 30:297-302.

HORACE, G. G. 1984. Potential impact of liberalized regulations to promote spike buck harvest. Proc. Southeastern Assoc. Fish Wildlife Agencies, 38:33-42.

Hovis, J. A., K. A. Cearley, S. L. Beasom, J. M. Inglis, AND A. R. Tipton. 1985. The effect of brush management on white-tailed deer populations. Caesar Kleberg Res. Prog. Wildlife Ecol., Ann. Rept. Texas Agric. Exp. Sta., p. 2.

HOWERY, L. D., AND J. A. PFISTER. 1985. Fecal nutrient levels in relation to diet of pen-fed whitetailed deer. Research Highlights-1985, Noxious Brush and Weed Control, Texas Tech Univ., 16:38.

1986. Fecal nutrient levels in relation to diet of pen-fed white-tailed deer. Research Highlights-1986, Noxious Brush and Weed Control, Texas Tech Univ., 17:33.

1990. Dietary and fecal concentrations of nitrogen and phosphorus in penned whitetailed deer does. J. Wildlife Manag., 54:383-389.

Howery, L. D., J. A. PFISTER, AND S. DemaraIS. 1989. Seasonal reproductive activity of 4 exotic ungulates in Texas. J. Wildlife Manag., 53:613-617.

Howery, L. D., J. A. PfISTER, S. Demarais, AND C. Lox. 1985. Pregnancy diagnosis in exotic ungulates using fecal levels of estradiol. Research Highlights-1985, Noxious Brush and Weed Control, Texas Tech Univ., 16:36.

- 1986. Pregnancy diagnosis in exotic ungulates using fecal and serum levels of estradiol. Research Highlights-1986, Noxious Brush and Weed Control, Texas Tech Univ., 17:31-32.

HUNDLEY, K. B., AND C. D. SimPSON. 1981. Life table analysis of the Welder Wildlife Refuge deer herd. Research Highlights-1981, Noxious Brush and Weed Control, Texas Tech Univ., 12:67-68.

HyDE, K. J., C. A. DeYoung, AND D. E. CAPEN. 1987. Short duration cattle grazing and habitat preference by white-tailed deer. Caesar Kleberg Res. Prog. Wildlife Ecol., Ann. Rept. Texas Agric. Exp. Sta., p. 6.

Hyde, K. J., C. A. Deyoung, AND A. Garza, JR. 1987a. Bed sites of white-tailed deer fawns in South Texas. Proc. Southeastern Assoc. Fish Wildlife Agencies, 41:288-293.

1987b. Bed sites of white-tailed deer fawns in South Texas. Caesar Kleberg Res. Prog. Wildlife Ecol., Ann. Rept. Texas Agric. Exp. Sta., p. 7.

1987c. Effects of short duration grazing on white-tailed deer movement. Caesar Kleberg Res. Prog. Wildlife Ecol., Ann. Rept. Texas Agric. Exp. Sta., p. 7.

1987d. The effects of short duration grazing on white-tailed deer. P. 21, in Tenth Ann. Meeting Southeast Deer Study Group, Gulf Shore, Alabama, 30 pp.

HYDE, K. J., A. GARZA, AND C. A. DEYOUNG. 1986. Effects of short duration grazing on whitetailed deer movement. Caesar Kleberg Res. Prog. Wildlife Ecol., Ann. Rept. Texas Agric. Exp. Sta., p. 13.

ILTON, D. A., J. G. TEER, AND N. J. SiLvy. 1987. Accuracy and precision of line transect procedures for white-tailed deer. Proc. Southeastern Assoc. Fish Wildlife Agencies, 41:424-431.

INGLIS, J. M. 1981. Do white-tails select amongst brush types? P. 14, in Fourth Ann. Meeting Southeast Deer Study Group. Tallahassee, Florida, 20 pp.

1985. Status of white-tailed deer on the Gibbon's Creek Lignite Project Area-1984. Rept. Texas Municipal Power Agency, Project 5142, Texas A\&M Research Found., 15 pp. (processed).

INGLIS, J. M., L. J. FolSE, AND J. H. RoESE. 1988. A white-tailed deer herd management system. Proc. 1988 Internat. Ranchers Roundup, San Antonio, Texas, pp. 146- 156 (processed). 
Inglis, J. M., B. A. Brown, C. A. McMahan, AND R. E. Hood. 1986. Deer-brush relationships on the Rio Grande Plains, Texas. RM14/KS6 Kleberg Stud., Caesar Kleberg Res. Prog. Wildlife Ecol., Dept. Wildlife Fisheries Sciences, Texas A\&M Univ., College Station, 80 pp.

JACKLEY, J. J., AND S. DEMARAIS. 1989a. Dietary overlap among axis, fallow, sika, and whitetailed deer in the Edwards Plateau region of Texas. Welder Wildlife Found. Biennial Rept., p. 12.

1989b. Dietary overlap among axis, fallow, sika, and white-tailed deer in the Edwards Plateau. Research Highlights-1989, Noxious Brush and Weed Control, Texas Tech Univ., 20:30.

1990. Diet overlap among axis, fallow, sika, and white-tailed deer in the Edwards Plateau Region. Research Highlights-1990, Noxious Brush and Weed Control, Texas Tech Univ., 21:18-19.

JenKS, J. A., R. L. LoChmilleR, AND E. C. HellGREN. 1990. Glycosylated hemoglobin as a stable alternative to serum glucose in white-tailed deer. Caesar Kleberg Res. Prog. Wildlife Ecol., Ann. Rept. Texas Agric. Exp. Sta., p. 26.

JURRIES, R. W., AND B. K. CARROLL. 1985. Survival of marked white-tailed deer fawns to adulthood in south-central Texas. P. 20, in Eighth Ann. Meeting Southeast Deer Study Group, Wilmington, North Carolina, 24 pp.

Kelley, J. K., R. L. Lochmiller, E. C. Hellgren, and W. E. Grant. 1987. Vitamin A levels of blood in collared peccaries (Tayassu tajacu) from South Texas. Comp. Biochem. Physiol., 86A:751-753.

KIDWELL, J., AND R. D. BROWN. 1986. Feed and water intake of penned white-tailed deer. Caesar Kleberg Res. Prog. Wildlife Ecol., Ann. Rept. Texas Agric. Exp. Sta., p. 29.

KIE, J. G., AND M. WhITE. 1985. Population dynamics of white-tailed deer (Odocoileus virginianus) on the Welder Wildlife Refuge, Texas. Southwestern Nat., 30:105-118.

KIE, J. G., D. L. DRAWE, AND G. SCOTT. 1980. Changes in diet and nutrition with increased herd size in Texas white-tailed deer. J. Range Manag., 33:28-34.

KIE, J. G., M. White, AND D. L. DRAWE. 1983. Condition parameters of white-tailed deer in Texas. J. Wildlife Manag., 47:583-594.

KinG, K. A., J. LeleuX, AND B. M. MulheRN. 1984. Molybdenum and copper levels in whitetailed deer near uranium mines in Texas. J. Wildlife Manag., 48:267-270.

KOERTH, B. H., L. J. KRYSL, B. F. SOWELL, AND F. C. BRYANT. 1981. Estimating seasonal diet quality of pronghorn antelope from fecal analysis. Research Highlights-1981, Noxious Brush and Weed Control, Texas Tech Univ., 12:75.

1984. Estimating seasonal diet quality of pronghorn antelope from fecal analysis. J. Range Manag., 37:560-564.

Koerth, B. H., B. F. Sowell, F. C. Bryant, AND E. P. Wiggers. 1985. Habitat relations of mule deer in the Texas Panhandle. Southwestern Nat., 30:579-587.

KoHL, T. F., AND S. L. BEASOM. 1984. Population responses of white-tailed deer to cattle grazing movement. Caesar Kleberg Res. Prog. Wildlife Ecol., Ann. Rept. Texas Agric. Exp. Sta., pp. 7-8.

Kohl, T. F., C. A. DeYoung, AND A. GARZA. 1985a. White-tailed deer productivity and condition under short duration vs. continuous grazing. Caesar Kleberg Res. Prog. Wildlife Ecol., Ann. Rept. Texas Agric. Exp. Sta., pp. 5-6.

$1985 \mathrm{~b}$. Effects of short duration grazing white-tailed deer movements. Caesar Kleberg Res. Prog. Wildlife Ecol., Ann. Rept. Texas Agric. Exp. Sta., p. 6.

1987. Effects of short duration grazing on deer home ranges. Proc. Southeastern Assoc. Fish Wildlife Agencies, 41:299-302. 
Kohl, T. F., S. L. Beasom, A. Garza, AND P. A. Schulz. 1984. The influence of short duration grazing on white-tailed deer movements. Caesar Kleberg Res. Prog. Wildlife Ecol., Ann. Rept. Texas Agric. Exp. Sta., pp. 6-7.

Kohl, T. F., T. Fulbright, A. GARZA, AND C. A. Deyoung. 1985. Effects of short duration grazing on cattle distribution. Caesar Kleberg Res. Prog. Wildlife Ecol., Ann. Rept. Texas Agric. Exp. Sta., pp. 6-7.

KoPf, V., R. D. Brown, AND D. L. DraWE. 1984. Prediction of protein intake in white-tailed deer in South Texas. J. Wildlife Manag., 48:518-520.

KothmanN, J. G. 1982. Status of pronghorn antelope in Texas. Proc. Antelope State Workshop, 10:39-42.

Krausman, P. R., AND E. D. Ables. 1981. Ecology of the Carmen Mountains white-tailed deer. U.S. Dept. Int., Nat. Parks Serv., Sci. Monogr. Ser., 15:1-114.

KRAUSMAN, P. R., AND B. D. LeOPOLD. 1988. Influence of large herbivores on Chihuahuan Desert vegetation. Southwestern Nat., 33:107-110.

KRONEMANN, L. A., AND C. BRITTON. 1982. Nutritional changes of selected wildlife browse after fire. Research Highlights_-1982, Noxious Brush and Weed Control, Texas Tech Univ., 13:70-71.

1983. Effects of fire on selected mule deer browse in the Guadalupe Mountains. Caesar Kleberg Found. Wildlife Conserv., Ann. Rept., Texas Tech Univ., 4:17-19.

Kronemann, L. A., C. D. Simpson, AND C. M. Britton. 1981. Nutritional changes of selected wildlife browse after fire. Research Highlights-1981, Noxious Brush and Weed Control, Texas Tech Univ., 12:75.

1982. Fire effects on ungulate browse in a desert shrub community. Caesar Kleberg Found. Wildlife Conserv., Ann. Rept., Texas Tech Univ., 3:27-29.

KROLL, J. C. 1990. Are streamside areas attractive to white-tailed deer? Pp. 11-12, in Thirteenth Ann. Meeting Southeast Deer Study Group. Pipestem, West Virginia, $26 \mathrm{pp}$.

KROLl, J. C., AND C. E. SAMFORD. 1983. Electric fences to control deer movements. P. 8, in Sixth Ann. Meeting Southeast Deer Study Group. Athens, Georgia, 27 pp.

KROLL, J. C., P. J. BEHRMAN, AND W. D. GoODRUM. 1986. Twenty-seven years of overbrowsing: implications to white-tailed deer management. Pp. 6-7, in Ninth Ann. Meeting Southeast Deer Study Group, Gatlinburg, Tennessee, 20 pp.

KROLL, J. C., R. L, RAYBURN, AND D. E. EVANS. 1983. Factors affecting home range size in whitetailed deer. Pp. 21-22, in Sixth Ann. Meeting Southeast Deer Study Group, Athens, Georgia, $27 \mathrm{pp}$.

Krueger, D. M., AND C. A. Deyoung. 1985. The effects of intensive, short duration cattle grazing on white-tailed deer. Welder Wildlife Found. Biennial Rept., p. 8.

KRYSL, L. J., J. D. MoODY, AND G. D. SimpSON. 1980. Mule deer food habits and preferences in Guadalupe Mountains National Park, Texas. P. 25, in Third Ann. Meeting Southeast Deer Study Group, Nacogdoches, Texas, $27 \mathrm{pp}$.

KrysL, L. J., C. D. Simpson, AND G. G. Gray. 1980. Dietary overlap of sympatric mule deer and barbary sheep in Palo Duro Canyon, Texas. Pp. 25-26, in Third Ann. Meeting Southeast Deer Study Group. Nacogdoches, Texas, $27 \mathrm{pp}$.

LAUTIER, J. K., T. V. DAILEY, AND R. D. BRowN. 1988. Effect of water restriction on feed intake of white-tailed deer. J. Wildlife Manag., 52:602-606.

LaUTiER, J. K., R. D. BRown, AND T. V. Dall.eY. 1987. Effect of water restriction on feed intake in white-tailed deer. Caesar Kleberg Res. Prog. Wildlife Ecol., Ann. Rept. Texas Agric. Exp. Sta., pp. 10-11. 
Lawrence, R. K., S. Demarais, R. D. Brown, and M. AbBotT. 1985. Nutrition effects on thyroid and ovarian activity and thymus weight in white-tailed deer. Research Highlights - 1985, Noxious Brush and Weed Control, Texas Tech Univ., 16:40.

- 1986. Nutritional effects on thyroids, ovaries, and thymuses in white-tailed deer. Proc. Southeastern Assoc. Fish Wildlife Agencies, 40:416-423.

- 1987. Nutritional effects on thyroids, ovaries, and thymuses in white-tailed deer. Caesar Kleberg Res. Prog. Wildlife Ecol., Ann. Rept. Texas Agric. Exp. Sta., pp. 32-33.

Lawrence, R. K., S. Demarais, and R. S. Lutz. 1990. Population dynamics and habitat selection of desert mule deer in the Trans Pecos region. Research Highlights-1990, Noxious Brush and Weed Control, Texas Tech Univ., 21:21.

LEE, T. 1987. Marketing hunting and the Sheffer experience. Proc. 1987 Internat. Ranchers Roundup, Kerrville, Texas, pp. 146-151 (processed).

LEE, T. E., JR., J. N. DERR, J. W. BICKHAM, AND T. L. CLARK. 1989. Genetic variation in pronghorn from West Texas. J. Wildlife Manag., 53:890-896.

Leopold, B. D., AND P. R. Krausman. 1983. Status of bighorn sheep in Texas. Texas J. Sci., 35:157-159.

1987a. Diurnal activity patterns of desert mule deer in relation to temperature. Texas J. Sci., 39:49-53.

1987b. Diets of two desert mule deer herds in Big Bend National Park, Texas. Southwestern Nat., 32:449-455.

LEON, F., AND S. BEASOM. 1984. Evaluation of census techniques for white-tailed deer. Caesar Kleberg Res. Prog. Wildlife Ecol., Ann. Rept. Texas Agric. Exp. Sta., pp. 22-23.

- 1985. Reliability of deer herd composition data obtained from helicopters. Caesar Kleberg Res. Prog. Wildlife Ecol., Ann. Rept. Texas Agric. Exp. Sta., p. 22.

LEON, F., S. L. BEASOM, AND D. SYNATZSKE. 1985a. Accuracy and precision of helicopter censusing for white-tailed deer. Caesar Kleberg Res. Prog. Wildlife Ecol., Ann. Rept. Texas Agric. Exp. Sta., p. 21.

- 1985b. Accuracy and precision of 3 white-tailed deer census techniques. Caesar Kleberg Res. Prog. Wildlife Ecol., Ann. Rept. Texas Agric. Exp. Sta., pp. $21-22$.

1985c. Accuracy and precision of helicopter censusing for white-tailed deer. Pp. 21-22, in Eight Ann. Meeting Southeast Deer Study Group, Wilmington, North Carolina, 24 pp.

LEON, F. G., III, C. A. DeYoung, AND S. L. BeASOM. 1987a. Bias in age and sex composition of white-tailed deer observed from helicopters. Wildlife Soc. Bull., 15:426-429.

1987b. Are deer encountered at random during helicopter surveys? Caesar Kleberg Res. Prog. Wildlife Ecol., Ann. Rept. Texas Agric. Exp. Sta., p. 18.

LoChmiller, R. L., AND W. J. ShefFIELD. 1989. Reproductive traits in male nilgai antelope in Texas. Southwestern Nat., 34:276-278.

Lochmiller, R. L., E. C. Hellgren, AND W. E. GRANT. 1984. Selected aspects of collared peccary (Dicotyles tajacu) reproductive biology in a captive Texas herd. Zoo Biol., 3:145-149. 1985a. Relationships between internal morphology and body mass in the adult collared peccary, Tayassu tajacu (Tayassuidae). Growth, 49:154-166.

$1985 \mathrm{~b}$. Sensitivity of the female collared peccary reproductive cycle to periodic malnutrition. P. 45, in First Peccary Workshop, Univ. Arizona, Tucson, $82+8$ unnumbered pp. 1986a. Reproductive responses to nutritional stress in adult female collared peccaries. J. Wildlife Manag., 50:295-300.

1986b. Absolute and allometric relationships between internal morphology and body mass in the adult collared peccary, Tayassu tajacu (Tayassuidae). Growth, 50:296-316. 1987. Physical characteristics of neonate, juvenile, and adult collared peccaries (Tayassu tajacu) from South Texas. J. Mamm., 68:188-194. 
1987. Influence of moderate nutritional stress during gestation on reproduction of collared peccaries. J. Zool., 211:321-328.

LOCHMRler, R. L., L. W. VARNER, AND W. E. GRANT. 1985a. Hematology of the collared peccary. J. Wildlife Manag., 49:66-71.

$1985 \mathrm{~b}$. Metabolic and hormonal responses to dietary restriction in adult female collared peccaries. J. Wildlife Manag., 49:733-741.

Lochmiller, R. L., E. R. Hellgren, W. E. Grant, AND L. W. VARner. 1985. Bone martow fat and kidney fat indices of condition in collared peccaries. J. Mamm., 66:790-795.

Lochmiller, R. L., E. C. Hellgren, L. W. VARNER, AND W. E. Grant. 1985. Serum and urine biochemical indicators of nutrition al status in adult female collared peccaries, Tayassu tajacu (Tayassuidae). Comp. Biochem. Physiol., 83A:473-485.

Lochmiller, R. L., E. C. Hellgren, W. E. Grant, L. W. Greene, and C. W. Dill. 1985. Description of collared peccary (Tayassu tajacu) milk composition. Zoo Biol., 4:375-379.

Lochmiller, R. L., E. C. Hellgren, L. W. Varner, K. McBeE, and W. E. Grant. 1989. Body condition indices for malnourished collared peccaries. J. Wildlife Manag., 53:205-209.

Lochmiller, R. L., E. C. Hellgren, L. W. Varner, L. W. Greene, M. S. Amoss, S. W. J. Seager, AND W. E. GRANT. 1985. Physiological responses of the adult male collared peccary, Tayassu tajacu (Tayassuidae), to severe dietary restriction. Comp. Biochem. Physiol., 82A:49-58.

Maltsberger, B. 1981. Trophy hunting south Texas style. Proc. 1981 Internat. Ranchers Roundup, Del Rio, Texas, pp. 396-397 (processed).

MCALPINE, S. 1990. Continued decline of elk populations within Guadalupe Mountains National Park, Texas. Southwestern Nat., 35:362-363.

MCCALL, T. C., AND R. D. BROWN. 1988. Comparison of tame deer enclosures and forage analyses for determining the carrying capacity of white-tailed deer. Caesar Kleberg Res. Prog. Wildlife Ecol., Ann. Rept. Texas Agric. Exp. Sta., p. 34.

MCCALL, T. C., R. D. BRown, AND T. Dalley. 1987. Comparison of 3 techniques for determining carrying capacity of white-tailed deer on South Texas ranches. P. 26, in Tenth Ann. Meeting Southeast Deer Study Group, Gulf Shores, Alabama, 30 pp.

MCCALL, T. C., R. D. Brown, AND C. A. Deyoung. 1987. Comparison of mortality of pen-raised deer to wild deer. Caesar Kleberg Res. Prog. Wildlife Ecol., Ann. Rept. Texas Agric. Exp. Sta., p. 21.

1988a. Comparitive mortality of pen-raised and wild white-tailed deer bucks. Caesar Kleberg Res. Prog. Wildlife Ecol., Ann. Rept. Texas Agric. Exp. Sta., p. 15.

1988b. Mortality of pen-raised and wild white-tailed deer bucks. Wildlife Soc. Bull., 16:380-384.

McCall, T. C., R. D. Brown, A. Garza, and T. V. Dalley. 1987. Comparison of tame deer enclosures and vegetation biomass techniques for assessing carrying capacity of whitetailed deer. Caesar Kleberg Res. Prog. Wildlife Ecol., Ann. Rept. Texas Agric. Exp. Sta., p. 11.

MCDonaLD, J. M. North American bison: their classification and evolution. Univ. California Press, Berkeley, $316 \mathrm{pp}$.

McLendon, T., M. W. Graham, M. C. Smith, R. M. Garcia, and H. L. Lieck, 1981. Productivity and vegetation response of a mesquite-mixed brush community utilized by 5 species of herbivores under semi-confinement. Caesar Kleberg Res. Prog. Wildlife Ecol., Ann. Rept. Texas Agric. Exp. Sta., pp. 9-10.

Mclendon, T., M. W. Graham, M. C. Smith, M. A. Bailey, S. C. Garner, R. J. Lamermayer, H. L. LIECK, AND C. E. TAYLOR. 1982. Productivity and vegetation response of a mesquite-mixed brush community utilized by 5 species of herbivores under semi- 
confinement. Caesar Kleberg Res. Prog. Wildlife Ecol., Ann. Rept. Texas Agric. Exp. Sta., pp. 31-40.

Meagher, M. 1986. Bison bison. Mamm. Species, 266:1-8.

MEIER, M. C. 1987. National forest system management perspectives: timer, livestock, wildlife. Proc. Southern Eval. Proj. Workshop, pp. 11-14.

MEYER, G. R. 1987. Game management for absentee land owners. Proc. 1987 Internat. Ranchers Roundup. Kerrville, Texas, pp. 125-130 (processed).

Meyer, M. W., R. D. Brown, AND M. W. Graham. 1984. Protein and energy content of whitetailed deer diets in the Texas Coastal Bend. J. Wildlife Mang., 48:527-534.

Meyer, M., M. Graham, AND R. D. Brown. 1984. Nutrient content of deer diets in South Texas. Caesar Kleberg Res. Prog. Wildlife Ecol., Ann. Rept. Texas Agric. Exp. Sta., p. 17.

Monson, G., And L. Sumner (eds.). 1980. The desert bighorn .... Univ. Arizona Press, Tucson, $\mathrm{xxii}+370 \mathrm{pp}$.

MorriLl, W. I. 1985. Deer census-how to use it to calculate harvest. Proc. 1985 Internat. Ranchers Roundup. Laredo, Texas, pp. 428-437 (processed).

MurPhy, B. R., L. M. SMITh, D. J. LeE, AND D. R. TerRE. 1988. Forensic discrimination of exotic and native ungulates. Wildlife Soc. Bull., 16:24-27.

NeLLE, S. 1984. Key food plants for deer-South Texas. Proc. 1984 Internat. Ranchers Roundup. San Angelo, Texas, pp. 281-291 (processed).

1985. How to manage for deer food. Proc. 1985 Internat. Ranchers Roundup. Laredo, Texas, pp. 417-427 (processed).

Nelson, J. T., AND K. GraCE. 1987. Habitat preference of elk in the Glass Mountains, Brewster County, Texas. Contrib. papers Second Symp. Resources Chihuahuan Desert region..., Chihuahuan Desert Res. Inst., Alpine, Texas, 11:1-5 (processed).

Oldenburg, P. W., P. J. ETtestad, W. E. Grant, And E. Davis. 1985a. Size, overlap, and temporal shifts of collared peccary herd territories in South Texas. J. Mamm., 66:378-380.

1985 $\mathrm{b}$. Structure of collared peccary herds in South Texas: spatial and temporal dispersion of herd members. J. Mamm., 66:764-770.

ORTEGA, I. M., AND F. C. BRYANT. 1987. Comparative diets of deer and cattle under short duration and continuous grazing. Welder Wildlife Found. Biennial Rept., pp. 10-11.

1989. Diets of white-tailed deer and cattle under short duration and continuous grazing. Welder Wildlife Found. Biennial Rept., p. 19.

ORTEGo, B., AND J. CAMPO. 1985. Helicopter drive trapping of deer in east Texas. P. 21, in Eight Ann. Meeting Southeast Deer Study Group, Wilmington, North Carolina, 24 pp.

OrTEGa, I. M., F. C. BryANT, AND S. Soltero. 1989. White-tailed deer diets under short duration and continuous grazing. Research Highlights-1989, Noxious Brush and Weed Control, Texas Tech Univ., 20:31-32.

1990. White-tailed deer and cattle diets under short duration and continuous grazing. Research Highlights-1990, Noxious Brush and Weed Control, Texas Tech Univ., 21:20.

Ortega, I. M., L. D. Perry, D. L. Drawe, and F. C. Bryant. 1988. Obtaining white-tailed deer fawns from wild-trapped does. Research Highlights-1988, Noxious Brush and Weed Control, Texas Tech Univ., 19:31-32.

1990. Observations on obtaining white-tailed deer fawns for experimental purposes. Texas J. Sci., 42:69-72.

OSBORN, D. A., AND S. DEMARAIS. 1987. Health status of sympatric populations of axis, fallow, sika, and white-tailed deer in the Edwards Plateau. Research Highlights-1987, Noxious Brush and Weed Control, Texas Tech Univ., 18:31. 
PACKARD, J. M., K. J. Babbitt, P. G. Hannon, AND W. E. Grant. 1990. Infanticide in captive collared peccaries (Tayassu tajacu). Zoo Biol., 9:49-53.

Packard, J. M., D. D. Dowdell, W. E. Grant, E. C. Hellgren, and R. L. Lochmiller. 1987. Parturition and related behavior of the collared peccary (Tayassu tajacu). J. Mamm., 68:679-681.

PAYNE, J. M. 1987. Impact of fee and lease hunting on wildlife management in Texas. P. 22, in Proc. Fifth National Extension Wildlife and Fisheries Workshop, Univ. Georgia, 95 pp.

PAYNE, R. M., AND C. D. SiMPSON. 1981. Pronghorn fawn home range expansion and movement. Research Highlights-1981, Noxious Brush and Weed Control, Texas Tech Univ., 12:76.

1982. Pronghorn fawn mortality in the Texas Panhandle. Caesar Kleberg Found. Wildlife Conserv., Ann. Rept., Texas Tech Univ., 3:22-23.

PAYNE, J. M., R. D. BRown, AND F. S. Guthery. 1987. Wild game in Texas. Rangelands, 9:207-211.

Pollock, M. T., S. Demarais, AND R. E. Zaiglin. 1988. Selection of habitat by mature male white-tailed deer during winter and spring in South Texas. Research Highlights-1988, Noxious Brush and Weed Control, Texas Tech Univ., 19:32.

- 1989. Selection of habitat characteristics by mature male white-tailed deer during winter and spring in South Texas. P. 21, in Twelfth Ann. Meeting Southeast Deer Study Group, Oklahoma City, $22 \mathrm{pp}$.

Pollock, M. T., S. Demarais, R. E. Zaiglin, and T. McNeil. 1987. An efficient mobile telemetry tower for radio-telemetry studies. Research Highlights-1987, Noxious Brush and Weed Control, Texas Tech Univ., 18:34.

Pollock, M. T., D. G. WhitTaker, S. Demarais, and R. E. Zaiglin. 1987. Seasonal habitat use by mature, male white-tailed deer in South Texas. Research Highlights-1987, Noxious Brush and Weed Control, Texas Tech Univ., 18:33-34.

PraSAD, N. L. N. S. 1985. A survey of management of blackbuck antelope in Texas. Caesar Kleberg Res. Prog. Wildlife Ecol., Ann. Rept. Texas Agric. Exp. Sta., p. 43.

Prasad, N. L. N. S., AND F. S. Guthery. 1984. Comparative wildlife use of water facilities with short duration and continuous grazing. Caesar Kleberg Res. Prog. Wildlife Ecol., Ann. Rept. Texas Agric. Exp. Sta., pp. 5-6.

- 1985. Wildlife use of water facilities under short duration and continuous grazing. Caesar Kleberg Res. Prog. Wildlife Ecol., Ann. Rept. Texas Agric. Exp. Sta., p. 5 (also in Welder Wildlife Biennial Rept., p. 9, under same title for same year).

Priebe, J. C., AND R. D. Brown. 1984. Digestive efficiency and protein requirements of nilgai antelope. Caesar Kleberg Res. Prog. Wildlife Ecol., Ann. Rept. Texas Agric. Exp. Sta., pp. 17-18.

Priebe, J. C., R. D. Brown, AND D. Swakon. 1984. Comparative in vitro digestive efficiency of cattle, goats, nilgai antelope, white-tailed deer, and collared peccaries. Caesar Kleberg Res. Prog. Wildlife Ecol., Ann. Rept. Texas Agric. Exp. Sta., p. 15.

RAKESTRAW, D. L., R. J. STAPPER, AND N. J. SiLVY. 1989. A comparison of three census methods for deer. P. 16, in Twelfth Ann. Meeting Southeast Deer Study Group, Little Rock, Arkansas, $19 \mathrm{pp}$.

RAmiReZ, V., AND R. D. BROWN. 1984. In vitro tissue incubation of white-tailed deer antler. Caesar Kleberg Res. Prog. Wildlife Ecol., Ann. Rept. Texas Agric. Exp. Sta., p. 37.

1985. In vitro incubation of deer antler tissue. Caesar Kleberg Res. Prog. Wildlife Ecol., Ann. Rept. Texas Agric. Exp. Sta.,p. 41.

RAMSEY. C. W. 1981. Use of deer census and harvest information. Proc. 1981 Internat. Ranchers Roundup, Del Rio, Texas, pp. 349-356 (processed).

1983. A look at ultralight aircraft for use in deer census. Proc. 1983 Internat. Ranchers Roundup, San Angelo, Texas, pp. 427-433 (processed). 
Rayburn, R. L., J. C. Kroll, AND D. E. Evans. 1983. Seasonal deer use of East Texas timber stands. Pp. 20-21, in Sixth Ann. Meeting Southeast Deer Study Group, Athens, Georgia, $27 \mathrm{pp}$.

RelyeA, R., AND S. Demarais. 1990. Movement and behavior of desert mule deer in the Trans Pecos Region. Research Highlights-1990, Noxious Brush and Weed Control, Texas Tech Univ., 21:20-21.

REYNOLDS, J. P., T. FUlbRight, AND S. L. BEASOM. 1988a. Effects of roller chopping rangeland on use by white-tailed deer and bobwhites. Caesar Kleberg Res. Prog. Wildlife Ecol., Ann. Rept. Texas Agric. Exp. Sta., pp. 23-24.

- $1988 b$. Effects of roller chopping on nutritional status of white-tailed deer. Caesar Kleberg Res. Prog. Wildlife Ecol., Ann. Rept. Texas Agric. Exp. Sta., p. 24.

1990. Effects of roller chopping a guajillo-blackbrush community on white-tailed deer diets. Caesar Kleberg Res. Prog. Wildlife Ecol., Ann. Rept. Texas Agric. Exp. Sta., p. 18.

RoEbuCK, C. M., AND C. D. Simpson. 1981. Food habits of pronghorn antelope and cattle in the Texas Panhandle. Research Highlights-1981, Noxious Brush and Weed Control, Texas Tech Univ., 12:76-77.

- 1982. Pronghorn and livestock food habits. Caesar Kleberg Found. Wildlife Conserv., Ann. Rept., Texas Tech Univ., 3:24-25.

Roebuck, C. M., B. E. Dahl, And C. D. Simpson. 1983. Pronghorn and livestock food habits. Caesar Kleberg Found. Wildlife Conserv., Ann. Rept., Texas Tech Univ., 4:24.

Roebuck, C. M., C. D. Simpson, AND B. E. DAHL. 1982. Food habits and preferences in three habitats of the Texas Panhandle. Proc. Antelope State Workshop, 10:71-85.

Rollins, D., AND F. C. BRYANT. 1981a. Managing ashe juniper for optimum white-tailed deer production on the Edwards Plateau. Research Highlights-1981, Noxious Brush and Weed Control, Texas Tech Univ., 12:66-67.

$1981 \mathrm{~b}$. Behavioral responses of exotic ungulates to brush clearing. Research Highlights-1981, Noxious Brush and Weed Control, Texas Tech Univ., 12:78.

1982a. Optimal clearing intensity for white-tailed deer on the Edwards Plateau. Research Highlights-1982, Noxious Brush and Weed Control, Texas Tech Univ., 13:72-73.

1982b. Response of exotic ungulates to brush control on the Edwards Plateau. Research Highlights-1982, Noxious Brush and Weed Control, Texas Tech Univ., 13:74-75.

Rollins, D., F. C. BRyant, AND R. Montondon. 1982. Fecal $\mathrm{pH}$ and defecation rates of eight ruminants fed controlled diets. Research Highlights-1982, Noxious Brush and Weed Control, Texas Tech Univ., 13:74.

Rollins, D., F. C. BRyant, D. D. Waid, AND L. C. Bradley. 1988. Deer response to brush management in central Texas. Wildlife Soc. Bull., 16:277-284.

Russ, W. B. 1983. Antelope status report of Texas. Proc. Antelope State Workshop, 11:31-32.

1984. Muleys and whitetails side by side. Texas Parks Wildlife, 42(11):30-34.

Ruthben, C., E. C. Hellgren, AND S. L. BeAsom. 1990. White-tailed deer nutrition and population status at 2 levels of brush diversity. Caesar Kleberg Res. Prog. Wildlife Ecol., Ann. Rept. Texas Agric. Exp. Sta., pp. 16-17.

SASSER, R. 1983. Woodland deer. Texas Parks Wildlife 41(11):2-7.

SChWEITZER, S., AND F. C. BRYANT. 1986. Establishment of browse and forbs on the Rolling Plains. Research Highlights-1986, Noxious Brush and Weed Control, Texas Tech Univ., 17:34.

1988. Improving Rolling Plains habitat for deer. Research Highlights-1988, Noxious Brush and Weed Control, Texas Tech Univ., 19:30-31. 
SCRIBNER, K. T., R. J. WARREN, AND S. L. BEASOM. 1983. Electrophoretic identification of whitetailed and mule deer fecal pellets. Research Highlights-1983, Noxious Brush and Weed Control, Texas Tech Univ., 14:54-55.

_. 1984a. Electrophoretic identification of white-tailed deer feces: a preliminary assessment. J. Wildlife Manag., 48:656-658.

1984b. Electrophoretic identification of white-tailed and mule deer fecal pellets. Pp. 1415, in Seventh Ann. Meeting Southeast Deer Study Group, Little Rock, Arkansas, 19 pp.

SCRiBner, J. H., W. E. Howard, R. TERANiShi, AND D. B. FAGRE. 1985. Toward a more effective coyote lure. Rangelands, 7:52-54.

Seager, S. W., S. J. Magyar, K. P. Coscarelli, E. C. Hellgren, R. L. Lochmiller, and W. E. GRANT. 1985. Electroejaculation and semen analysis in the collared peccary. Pp. 6061 , in First Peccary Workshop, Univ. Arizona, Tucson, $82+8$ unnumbered pp.

SERGIO, S., AND F. C. BRYANT. 1987. Comparative nutrition of deer and cattle under short duration and continuous grazing. Welder Wildlife Found. Biennial Rept., p. 11.

ShackLETON, D. M. 1985. Ovis canadensis. Mamm. Species, 230:1-9.

SHEFFIELD, W. J. 1983. Food habits of nilgai antelope in Texas. J. Range Manag., 36:316-322.

Shively, C. L., F. M. Whiting, R. S. Swingle, W. H. Brown, AND L. K. SowlS. 1985. Some aspects of the nutritional biology of the collared peccary. J. Wildlife Manag., 49:729-732.

SHuLT, M. J. 1984. Wildlife management alternatives for large or small ranches. Proc. 1984 Internat. Ranchers Roundup, San Angelo, Texas, pp. 347-352 (processed).

SHUPE, T. E., AND S. L. BEASOM. 1987. Response of a white-tailed deer herd to managed harvest. Caesar Kleberg Res. Prog. Wildlife Ecol., Ann. Rept. Texas Agric. Exp. Sta., pp. 22-23.

ShUPE, T. E., S. L. BEASOM, AND F. LEON. 1985. Effects of helicopter speed on census of whitetailed deer. Caesar Kleberg Res. Prog. Wildlife Ecol., Ann. Rept. Texas Agric. Exp. Sta., pp. 22-23.

- 1986. Effects of helicopter altitude on census of white-tailed deer. Caesar Kleberg Res. Prog. Wildlife Ecol., Ann. Rept. Texas Agric. Exp. Sta., p. 21.

Simpson, C. D., AND G. G. GraY. 1983. Topographic and habitat use by sympatric barbary sheep and mule deer in Palo Duro Canyon, Texas. J. Range Mang., 36:190-194.

SMITH, M., AND S. C. GARNER. 1983. Effect of range burning on white-tailed deer diets on a South Texas mesquite shrubland. Caesar Kleberg Res. Prog. Wildlife Ecol., Ann. Rept. Texas Agric. Exp. Sta., p. 37.

Smith, M., J. D. Williams, AND D. S. Davis. 1986. Harvest strategies inside a deer proof fence with supplementation and live-stock removal. P. 3, in Ninth Ann. Meeting Southeast Deer Study Group, Gatlingburg, Tennessee, $20 \mathrm{pp}$.

SMITH, S. C., R. J. WARREN, AND B. R. MuRPhy. 1984. Hybridization of white-tailed deer and mule deer in the Trans Pecos region of Texas. Research Highlights-1984, Noxious Brush and Weed Control, Texas Tech Univ., 15:39-40.

1985. Hybridization of white-tailed deer and mule deer in the Trans-Pecos region of Texas. Caesar Kleberg Found. Wildlife Conserv. Ann. Rept., Texas Tech Univ., 6:15.

SMITH-STUBblefield, S. C., R. J. WARREN, AND B. R. MuRPhy. 1985. Hybridization of white-tailed deer and mule deer in the Trans Pecos region of Texas. Research Highlights-1985, Noxious Brush and Weed Control, Texas Tech Univ., 16:34-35.

Soltero, S., F. C. BRyAnT, AND I. M. ORTEGA. 1988. Deer habitat response to grazing systems and stocking rates. Research Highlights-1988, Noxious Brush and Weed Control, Texas Tech Univ., 19:30.

1989. Deer habitat response to grazing systems and stocking rates. Research Highlights-1989, Noxious Brush and Weed Control, Texas Tech Univ., 20:31. 
1990. Crude protein and digestibility of common forages of deer and cattle. Research Highlights-1990, Noxious Brush and Weed Control, Texas Tech Univ., 21:20.

Soltero-Gardea, S., AND F. C. BRYANT. 1989. Comparative nutrition of deer and cattle under short duration and continuous grazing. Welder Wildlife Found. Biennial Rept., pp. 19-20.

Sowel., B. F., B. H. KoERTH, AND F. C. BRYANT. 1981. Nutritional quality of mule deer diets in the Texas Panhandle. Research Highlights-1981, Noxious Brush and Weed Control, Texas Tech Univ., 12:74.

1985. Seasonal nutrient estimates of mule deer diets in the Texas Panhandle. J. Range Manag., 38:163-166.

Sowls, L. N. 1984. The peccaries. Univ. Arizona Press, Tucson, xvi +251 pp.

Stangl, F. B., JR., AND W. W. Dalquest, 1990. Status of the javelina, Tayassu tajacu, in northcentral Texas and southern Oklahoma. Texas J. Sci., 42:305-306.

STEPHENSON, D. C., AND R. D. BRown. 1984. Calcium absorption in male white-tailed deer. Caesar Kleberg Res. Prog. Wildlife Ecol., Ann. Rept. Texas Agric. Exp. Sta., p. 36.

STREY, O. F., III, AND R. D. BRown. 1984. Forage digestibilities for the 5 major herbivores of South Texas. Caesar Kleberg Res. Prog. Wildlife Ecol., Ann. Rept. Texas Agric. Exp. Sta., p. 15.

- 1985. Comparative in vivo-in vitro digestibilities for the 5 major herbivores of South Texas. Caesar Kleberg Res. Prog. Wildlife Ecol., Ann. Rept. Texas Agric. Exp. Sta., p. 39.

1987. In vivo and in vitro digestibilities for white-tailed deer, collared peccaries, and nilgai antelope. Caesar Kleberg Res. Prog. Wildlife Ecol., Ann. Rept. Texas Agric. Exp. Sta., p. 32.

- 1989a. Estimating digestibilities for white-tailed deer in South Texas. Texas J. Sci., 41:215-222.

$1989 \mathrm{~b}$. In vivo and in vitro digestibilities for collared peccaries. J. Wildlife Manag., 53:607-612.

StREy, O. F., G. R. CARL, J. C. Priebe, AND R. D. Brown. 1986. In vivo and in vitro digestion trials for collared peccaries in South Texas. P. 57, in Proc. Peccary Workshop (R. A. Okenfel, G. I. Day, and V. C. Supplee, eds.), Arizona Game and Fish Dept., Phoenix, 82 pp.

Stubblefield, S. S., R. J. WARREN, AND B. R. MurPhy. 1986. Hybridization of free-ranging white-tailed and mule deer in Texas. J. Wildlife Manag., 509:688-690.

Stuth, J. W., AND W. J. ShefField. 1986. Determining carrying capacity for combinations of livestock, white-tailed deer, and exotic ungulates. Proc. 1986. Internat. Ranchers Roundup, Kerrville, Texas, pp. 241-254 (processed).

Sullivan, J. B., C. A. Deyoung, S. L. Beasom, J. Heffelfinger, and S. Coughlin. 1990. Evaluation of bias in the proportion of fawns sighted during fall helicopter surveys. Caesar Kleberg Res. Prog. Wildlife Ecol., Ann. Rept. Texas Agric. Exp. Sta., p. 2.

Sullivan, J. B., C. A. Deyoung, S. L. Beasom, J. Heffelfinger, S. Coughlin, AND M. W. HelLICKSON. 1990. Drive-netting deer: incidence of myopathy and mortality. Caeser Kleberg Res. Prog. Wildlife Ecol., Ann. Rept. Texas Agric. Exp. Sta., p. 23.

SwaKon, D. H. D., R. D. Brown, AND G. KNOWLES. 1982. The comparative digestive efficiency of cattle, goats, deer, and horses. Caesar Kleberg Res. Prog. Wildlife Ecol., Ann. Rept. Texas Agric. Exp. Sta., p. 17.

- 1983. The comparative digestive efficiency of cattle, goats, deer, and horses. Caesar Kleberg Res. Prog. Wildlife Ecol., Ann. Rept. Texas Agric. Exp. Sta., p. 7.

SwANK, W. G. 1981. Wildlife laws and their effect of deer management. Proc. 1981. Internat. Ranchers Roundup. Del Rio, Texas, pp. 361-366 (processed).

SWEPSTON, D. A. 1982. Texas wapiti. Texas Parks Wildlife, 40(9):8-11. 
SYNATZSKE. D. R. 1981. Effectiveness of muzzle-loading firearms in harvesting white-tailed deer in Texas. P. 11, in Fourth Ann. Meeting Southeast Deer Study Group, Tallahassee, Florida, $20 \mathrm{pp}$.

1990. Effects of stand vs. pasture hunting on white-tailed deer harvest in south Texas. P. 10, in Thirteenth Ann. Meeting Southeast Deer Study Group, Pipestem, West Virginia, $26 \mathrm{pp}$.

TeER, J. G. 1984. Lessons from the Llano Basin, Texas. Pp. 261-290, in White-tailed deer ecology and management (L. K. Halls, ed.), Wildlife Manag. Inst., Washington, D. C., and Stackpole Books, Harrisburg, Pennsylvania, xxiii +870 pp.

TEGARDEN, C. H., AND D. H. S. SWAKON. 1988. Quality and acceptability of nilgai antelope meat. Caesar Kleberg Res. Prog. Wildlife Ecol., Ann. Rept. Texas Agric. Exp. Sta., p. 18.

ThоmAs, J. K., AND C. E. ADAMS. 1985. Socioeconomic factors affecting land access to hunt white-tailed deer. Wildlife Soc. Bull., 13:388-394.

TUCKER, R. D., AND G. W. GARNER. 1983. Habitat selection and vegetational characteristics of antelope fawn bedsites in West Texas. J. Range Manag., 36:110-113.

1984. Home range and diel movements of pronghorn antelope fawns in Brewster County, Texas. Proc. Antelope Workshop, 11:71-89.

Van Der Eems, K., AND R. Brown. 1986. Vitamin D in white-tailed deer. Caesar Kleberg Res. Prog. Wildlife Ecol., Ann. Rept. Texas Agric. Exp. Sta., pp. 29-30.

VARNER, L. W., AND L. H. BLANKENSHIP. 1985. Southern Texas shrubs-nutritive value and utilization by herbivores. Proc. Symp. Plant-Herbivore Interactions, Snowbird, Utah, pp. 108-112 (processed).

VARNER, L. W., L. H. BlankENSHIP, AND S. E. HEINEMAN. 1985. Nutritional value of deer food plants in South Texas. Proc. First Internat. Wildlife Symp., Mexico City, 2:1001-1017.

Van VReEde, G. B., F. C. BRyant, T. J. Deliberto, and K. GeE. 1987. Evaluation of forage preferences indices for white-tailed deer. Research Highlights-1987, Noxious Brush and Weed Control, Texas Tech Univ., 18:31-32.

Van VReede, G., L. C. Bradley, F. C. Bryant, and T. L. DeliberTo. 1989. Evaluation of forage preference indices for white-tailed deer. J. Wildlife Manag., 53:210-213.

WAID, D. D., AND R. J. WARREN. 1981. Brush control in white-tailed deer management on the Edwards Plateau. Research Highlights-1981, Noxious Brush and Weed Control, Texas Tech Univ., 12:68-69.

1982a. Effects of brush control on physiological indices in white-tailed deer. Research Highlights-1982, Noxious Brush and Weed Control, Texas Tech Univ., 13:70.

1982b. Evaluation of diet composition from rumen samples of white-tailed deer. Research Highlights-1982, Noxious Brush and Weed Control, Texas Tech Univ., 13:71-72.

1983. Seasonability of white-tailed deer diets and nutritional status in central Texas. Research Highlights-1983, Noxious Brush and Weed Control, Texas Tech Univ., 14:54.

1984. Seasonality of white-tailed deer diets and nutritional status in central Texas. Pp. 11-12, in Seventh Ann. Meeting Southeast Deer Study Group, Little Rock, Arkansas, 19 pp.

WAID, D. D., R. J. WARREN, AND D. B. PEnCE. 1984. Ecology of mountain lions in the vicinity of Big Bend National Park and the Trans-Pecos region of Texas. Caesar Kleberg Found. Wildlife Conserv., Ann. Rept., Texas Tech Univ., 5:7.

WALl, W. A., J. C. KROLL, W. D. Goodrum, AND D. Whitehouse. 1986. Do differential harvest strategies affect genetic variability in white-tailed deer populations? Pp. 1-2, in Ninth Ann. Meeting Southeast Deer Study Group, Gatlingburg, Tennessee, 20 pp. 
Wall, W. A., T. Bourland, D. Stewart, C. Hamilton, and J. Kroll. 1988. The biology and sociology of a mandated quality deer management program. Pp. 10-11, in Eleventh Ann. Meeting Southeast Deer Study Group, Paducah, Kentucky, 26 pp.

Walmo, O.C. (ed.). 1981. Mule and black-tailed deer of North America. Univ. Nebraska Press, Lincoln, $x$ vii $+605 \mathrm{pp}$.

WALSh, P. B., AND J. M. INGLIS. 1985. Population fluctuations of white-tailed deer on a ranch in South Texas. P. 19, in Eighth Ann. Meeting Southeast Deer Study Group, Wilmington, North Carolina, $24 \mathrm{pp}$.

WARD, R. G., AND M. L. KIMANI. 1984. Mineral and protein content of white-tailed deer ranges under 2 grazing management systems. Caesar Kleberg Res. Prog. Wildlife Ecol., Ann. Rept. Texas Agric. Exp. Sta., pp. 8-9.

WARD, R. G., D. S. DAVIS, AND C. TEGARDEN. 1984. Harvesting and marketing nilgai antelope. Caesar Kleberg Res. Prog. Wildlife Ecol., Ann. Rept. Texas Agric. Exp. Sta., p. 23.

WARREN, R. J., AND L. J. KRYSL. 1981. Comparative food habits and nutritional status of whitetailed deer in central Texas. Research Highlights-1981, Noxious Brush and Weed Control, Texas Tech Univ., 12:70.

1983. White-tailed deer food habitats and nutritional status as affected by grazing and deer-harvest management. J. Range Manag., 36:104-109.

WEAVER, R. A. 1986. Status of desert bighorn sheep in the U. S. and current management programs. North American Wildlife Nat. Res. Conf., 51:41.

Weishunn, L. L. 1983. Management of white-tailed deer of South Texas ranges. Pp. 349-354, in Antler development in Cervidae (R. D. Brown, ed.), Proc. First Internat. Symp. Caesar Kleberg Wildlife Res, Ins., Kingsville, Texas, xiii + 480 pp.

Weldon, P, J., S. A. Smith, AND E. C. Hellgren. 1990. Scent gland secretions and their role in javelina behavior. Caesar Kleberg Res. Prog. Wildlife Ecol., Ann. Rept. Texas Agric. Exp. Sta., p. 26.

WELGE, H. 1981. High deer numbers and high harvest for a profit. Proc. 1981 Internat. Ranchers Roundup, Del Rio, Texas, pp. 382-389 (processed).

Wheaton, C. 1985. Panhandle mule deer. Texas Parks Wildlife, 43(3):42-44.

WhEATON, C., AND R. D. BRown. 1982. Seasonal variation in feed intake and digestive efficiency in South Texas white-tailed deer. Pp. 13-14, in Fifth Ann. Meeting Southeast Deer Study Group, Charleston, South Carolina, $24 \mathrm{pp}$.

1983. Feed intake and digestive efficiency of South Texas white-tailed deer. J. Wildlife Manag., 47:442-452.

Whitehouse, D. B., R. E. Zaiglin, And K. R. Xerriman. 1985. Preliminary results of an intensive white-tailed deer management program in the post oak region of Texas. P. 14, in Eighth Ann. Meeting Southeast Deer Study Group, Wilmington, North Carolina, 24 pp.

WhitTAKer, D. G., S. Demarais, AND R. D. Zaiglin, 1989. Summer and fall habitat selection by mature, male white-tailed deer in southern Texas. Research Highlights-1989, Noxious Brush and Weed Control, Texas Tech Univ., 20:30-31.

WIGGERS, E. P., AND S. L. BEASOM. 1981. Characterization of overlapping mule and white-tailed deer range in West Texas. Research Highlights--1981, Noxious Brush and Weed Control, Texas Tech Univ., 12:72.

1982. Characterization of overlapping desert mule deer and white-tailed deer habitat in West Texas. Research Highlights-1982, Noxious Brush and Weed Control, Texas Tech Univ., 13:73-74.

1986. Characterization of sympatric of adjacent habitats of 2 deer species in West Texas. J. Wildlife Manag., 50:129-134. 
WigGERS, E. P., D. D. WILCOX, AND F. C. BryANT. 1984. Cultivated cereal grains as supplemental forages for mule deer in the Texas Panhandle. Wildlife Soc. Bull., 12:240-245.

WIGGERS, E. P., S. L. BEASOM, B. RUSS, AND S. SOROLA. 1981. Recent history of woody vegetation and deer species composition changes along the Pecos River, Texas. Research Highlights-1981, Noxious Brush and Weed Control, Texas Tech Univ., 12:71-72.

1988. Recent changes in woody brush and deer abundance along the Pecos River, Texas. Contrib. Papers Second Symp. Resources Chihuahuan Desert region .... Chihuahuan Desert Res. Inst., Alpine, Texas, 18:1-6 (processed).

WILCOX, D., AND F. C. BRYANT. 1981. Evaluating mule deer preferences of cultivated annual grasses using time-lapse photography. Research Highlights-1981, Noxious Brush and Weed Control, Texas Tech Univ., 12:74-75.

Williams, J. D., AND D. E. HaRmel. 1984. Selection for antler points and body weight in whitetailed deer. Proc. Southeastern Assoc. Fish Wildlife Agencies, 38:43-50.

1985. Phenotypic variability among white-tailed deer with 8 antler points at 2.5 years. P. 13, in Eighth Ann. Meeting Southeast Deer Study Group, Wilmington, North Carolina, $24 \mathrm{pp}$.

_ 1986a. Effect of early weaning on 180 day body measurements on white-tailed deer. Pp. 14-15, in Ninth Ann. Meeting Southeast Deer Study Group, Gatlinburg, Tennessee, 20 pp.

1986b. Predicting mature antler characteristics from yearling white-tailed deer. Pp. 1920, in Ninth Ann. Meeting Southeast Deer Study Group, Gatlingburg, Tennessee, 20 pp. 1988a. Predicting mature antler characteristics for yearling white-tailed deer. P. 10, in Eleventh Ann. Meeting Southeast Deer Study Group, Paducah, Kentucky, 26 pp.

1988b. Heritability estimates in white-tailed deer-progress report. Pp. 12-13, in Eleventh Ann. Meeting Southeast Deer Study Group, Paducah, Kentucky, 26 pp.

WINKLER, C. 1983. Raising bighorns. Texas Parks Wildlife, 41(10):22-24.

1988. Never say die. Texas Parks Wildlife, 46(6):12-17.

WINKLER, C. K. 1981 a. Texas' antlerless deer hunting system: methods and effectiveness. Proc. Southeastern Assoc. Fish Wildlife Agencies, 35:292-296.

- $1981 b$. Texas' antlerless deer hunting system: methods and effectiveness. P. 4, in Fourth Ann. Meeting Southeast Deer Study Group, Tallahassee, Florida, 20 pp.

- 1983. Deer management plans for private lands in Texas. Proc. Southeastern Assoc. Fish Wildlife Agencies, 37:14-18.

WinkLer, C. K., R. L. CoOK, AND W. F. Harwell. 1981. Whitetails in Texas. Part 1. The central ranges. Texas Parks Wildlife, 39(11):2-7.

1981. Whitetails in Texas. Part 2. The eastern range. Texas Parks Wildlife, 39(12):1013.

1982. Whitetails in Texas. Part 3. The western ranges. Texas Parks Wildlife, 40(1):2427.

WRAY, T., T. F. KOHL, AND S. L. BEASOM. 1984. Diet analysis of white-tailed deer and cattle under different grazing regimes. Caesar Kleberg Res. Prog. Wildlife Ecol., Ann. Rept. Texas Agric. Exp. Sta., p. 7.

Yantis, J. H., C. D. Frentress, W. S. Daniel, AND G. H. Veteto. 1983. Deer management in the post oak belt. Texas Parks and Wildlife Dept., P-R Prof. Rept. W-109-R and W-54-D, 28 pp. (processesd).

YARrow, G. K., AND J. K. KROLL. 1989. Coexistence of white-tailed deer and feral hogs: management implications. Pp. 13-14, in Twelfth Ann. Meeting Southeast Deer Study Group, Oklahoma City, 22 pp. 
ZaIGLIN, B., AND S. DemaraIS. 1987. Video-selective capture of white-tailed deer with a helicopter-assisted drive net. P. 17, in Tenth Ann. Meeting Southeast Deer Study Group, Gulf Shores, Alabama, $30 \mathrm{pp}$.

ZaIGLIN, R. E. 1987. Hunting program development. Proc. 1987 Internat. Ranchers Roundup, Kerrville, Texas, pp. 155-159 (processed).

Zaiglin, R. E., AND C. A. Deyoung. 1990. Supplemental feeding of free-ranging deer in South Texas. Texas J. Agric. Nat. Res., 3:39-41.

ZAIGLIN, R. E., AND L. SUMNER. 1987. The initiation and application of a white-tailed deer management program on a private ranch in South Texas. P. 10, in Tenth Ann. Meeting Southeast Deer Study Group, Gulf Shores, Alabama, 30 pp.

\section{Parasites and Diseases}

Anderson, R. C., AND A. K. Prestwood. 1981. Lungworms. Pp. 266-317, in Diseases and parasites of white-tailed deer (W. R. Davidson et al., eds.), Misc. Publ. Tall Timbers Res. Sta., Tallahassee, Florida, 7:1-458 pp.

Anonymous. 1980. Rabid bats in Texas classrooms. Bull. Field Mus. Nat. Hist., 51:24.

BARNES, A. M., V. J. TIPTON, AND J. A. WILDIE. 1977. The subfamily Anomiopsyllinae (Hystrichopsyllidae: Siphonaptera). I. A revision of the genus Anomiopsyllus Baker. Great Basin Nat., 37:138-206.

Blume, R. R., AND A. AGA. 1979. Additional records of Aphodius from pocket gopher burrows in Texas (Coleoptera: Scarabaeidae). Coleopt. Bull., 33:131-132.

Blume, R. R., AND J. W. Summerlin. 1988. Histeridae (Coleoptera) from pocket gopher burrows (Geomyidae) in east-central Texas. Coleopt. Bull., 42:202-204.

BURGESS, E., AND L. A. WINDBERG. 1989. Borrelia sp. infection in coyotes, black-tailed jackrabbits and desert cottontails in southern Texas. J. Wildlife Dis., 25:47-51.

CLARK, K. A. 1984. Rabies epidemiology: wildlife reservoirs in Texas. J. Amer. Vet. Med. Assoc., 185:329.

Clark, K. A., S. H. Kim, L. F. Boening, M. J. Taylor, T. G. BetZ, and F. V. McCasland. 1987. Leprosy in armadillos (Dasypus novemcinctus) from Texas. J. Wildlife Dis., 23:220-224.

Constantine, D. G. 1986. Absence of prenatal infection of bats with rabies virus. J. Wildlife Dis., 22:249-250.

CORN, J. L., D. B. PENCE, AND R. J. WARREN. 1985. Factors affecting the helminth community structure of adult collared peccaries in southern Texas. J. Wildlife Dis., 21:254-263.

Craig, T. M., J. M. Bowen, AND K. G. Ludwig. 1983. Transmission of equine cyathostomes (Strongylidae) in central Texas. Amer. J. Vet. Res., 44:1867-1869.

CUSTER, J. W., AND D. B. PENCE. 1981a. Ecological analyses of helminth populations of wild canids from the Gulf Coastal prairies of Texas and Louisiana. J. Parasitol., 67:289-307. 1981 b. Dirofilariasis in wild canids from the Gulf Coastal prairies of Texas and Louisiana, U.S.A. Vet. Parasit., 8:71-82.

1981c. Host-parasite relationships in wild canids of North America. II. Ecology of helminth infections in the genus Canis. Proc. Worldwide Furbearer Conf., pp. 730-750.

DAVIS, D. S. 1980. Serologic survey of four zoonotic diseases in coyotes (Canis latrans) in selected areas of Texas. Diss. Abstr. Internat. (B), 40:3610.

1983. Experimental infection of nilgai antelope with Brucella abortus strain. Caesar Kleberg Res. Prog. Wildlife Ecol., Ann. Rept. Texas Agric. Exp. Sta., p. 14.

1984. Experimental infection of nilgai antelope with bovine brucellosis and interspecific transmission trials to susceptible cattle. Caesar Kleberg Res. Prog. Wildlife Ecol., Ann. Rept. Texas Agric. Exp. Sta., pp. 18. 
DAVIS, D. S., AND T. QURESHI. 1983. The use of albendazole-treated feed to control Fascioloides magna infections in captive white-tailed deer. Caesar Kleberg Res. Prog. Wildlife Ecol., Ann. Rept. Texas Agric. Exp. Sta., p. 13.

DAVIS, D. S., T. G. ADAMS, AND J. D. Williams. 1985. Experimental infection of captive-raised white-tailed deer with bovine brucellosis. Caesar Kleberg Res. Prog. Wildlife Ecol., Ann. Rept., Texas Agric. Exp. Sta., p. 18.

DAvis, D. S., T. QURESHI, AND R. M. RoBINSON. 1985. Encephalitis-like disease of javelina in South Texas. Caesar Kleberg Res. Prog. Wildlife Ecol., Ann. Rept. Texas Agric. Exp. Sta., p. 17-18.

DAVIS, J. W., L. H. KARSTAD, AND D. O. Trainer. 1981. Infectious diseases of wild mammals. Iowa State Univ. Press, Ames, $446 \mathrm{pp}$.

Demarais, S., AND M. L. RiChARDSON. 1983. Comparison of parasites from sympatric endemic and exotic ruminant populations in South-Central Texas. Caesar Kleberg Res. Prog. Wildlife Ecol., Ann. Rept. Texas Agric. Exp. Sta., pp. 16-17.

Demarais, S., M. L. Richardson, AND D. S. Davis. 1984. Parasites of native and exotic deer under different livestock grazing systems on the Edwards Plateau. Caesar Kleberg Res. Prog. Wildlife Ecol., Ann. Rept. Texas Agric. Exp. Sta., p. 9.

EAdS, R. B., E. G. CAMPOS, AND G. O. MAUPIN. 1987. A review of the genus Meringis (Siphonaptera: Hystrichopsyllidae). J. Med. Ent., 24:467-476.

EMERSON, K.C., AND R. D. PRICE. 1979. Two new species of Bovicola (Mallophaga: Trichodectidae). J. Kansas Ent. Soc., 52:747-750.

1983. A review of the Felicola felis complex (Mallophaga: Trichodectidae) found on New World cats (Carnivora: Felidae). Proc. Ent. Soc. Washington, 85:1-9.

Fain, A., J. O. WhitaKeR, JR., AND H. H. Thomas. 1988. Two new species of Geomylichus Fain, 1970 (Acari, Listrophoridae) from California, U.S.A. Internat. J. Acarol., 14:121-125.

Fain, A., J. O. Whitaker, JR., T. G. SChwan, AND F. S. Lukoschus. 1978. Notes on the genus Geomylichus Fain, 1970 (Astigmata, Listrophoridae) and description of six new species. Internat. J. Acarol., 4:101-114.

FEDYNICH, A. M., D. B. PENCE, AND R. L. URUBEK. 1986. Helminth fauna of beaver from central Texas. J. Wildlife Dis., 22:579-582.

Fishbein, D. B., A. J. Belotto, R. E. PACER, J. S. Smith, W. G. Winkler, S. R. Jenkins, AND K. M. PORTER. 1986. Rabies in rodents and lagomorphs in the United States, 1971-1984: increased cases in the woodchuck (Marmota monax) in mid-Atlantic states. J. Wildlife Dis., 22:151-155.

FORD, P. L., AND D. W. DUSZYNSKI. 1988. Coccidian parasites (Apicomplexa: Eimeriidae) from insectivores. 6. Six new species from the eastern mole, Scalopus aquaticus. J. Protozool., 35:223-226.

FORD, P. L., D. W. DUSZYNSKI, AND C. T. MCAllisteR. 1990. Coccidia (Apicomplexa) from heteromyid rodents in the southwestern United States, Baja California, and northern Mexico with three new species from Chaetodipus hispidus. J. Parasit., 76:325-331.

FOREYT, W. J., AND D. L. DRAWE. 1985. Efficacy of clorsulon and albendazole against Fascioloides magna in naturally infected white-tailed deer. J. Amer. Vet. Med. Assoc., 187:1187-1188.

FOREYT, W. J., AND J. F. EVERMANN, 1985. Serologic survey of canine coronavirus in wild coyotes in the western United States, 1972-1982. J. Wildlife Dis., 21:428-430.

GARNETT, W. H., AND E. H. AHRENS. 1979. A tick survey of white-tailed deer in eight south Texas counties. Southwestern Ent., 4:192-194. 
GARnham, P. C. C., AND K. L. KuTtLeR. 1980. A malaria parasite of the white-tailed deer (Odocoileus virginianus) and its relation with known species of Plasmodium in other ungulates. Proc. Royal Soc. London (B), 206:395-402.

Gladney, W. J., C. C. DaWkins, AND M. A. PRICE. 1977. Amblyomma inornatum (Acarina: Ixodidae): Natural hosts and laboratory biology. J. Med. Ent., 14:85-88.

GoFF, W. L., AND N. C. RoNALD. 1979. The rolling plains of Texas. Internat. J. Parasit., 9:339-344. 1981. Certain aspects of the biology and life cycle of Heterobilharzia americana in east central Texas. Amer. J. Vet. Res., 42:1775-1777.

GRöGL, M., R. E. KUHN, D. S. DAVIS, AND G. E. GREEN. 1984. Antibodies to Trypanosoma cruzi in coyotes in Texas. J. Parasit., 70:189-191.

Guo, W., J. F. Evernmann, J. F. Foreyt, F. F. Knowlton, And L. A. WindberG. 1986. Canine distemper virus in coyotes: a serological survey. J. Amer. Vet. Med. Assoc., 189:1099-1100.

Hannon, P. G., R. L. Lochmiller, J. W. Mellen, T. M. Craig, and W. E. Grant. 1985. Eperythrozoon in captive juvenile collared peccaries in Texas. J. Wildlife Dis., 21:439-440.

Hellenthal, R. A., AND R. D. Price. 1989. Geomydoecus (Mallophaga: Trichodectidae) from the Texas and desert pocket gophers (Rodentia: Geomyidae). Proc. Ent. Soc. Washington, 91:1-8.

HELLGREN, E. C., R. L. LoCHMILLER, AND W. E. GRANT. 1984. Infection of captive adult collared peccaries, Dicotyles tajacu (Woodburne, 1968), with the nematode, Ascaris sum (Goeze, 1782). Proc. Helminth. Soc. Washington, 51:160-161.

Hellgren, E. C., R. L. Lochmiller, M. A. Amoss, JR., AND W. E. Grant. 1985. Endocrine and metabolic infection in captive juvenile collared peccaries in Texas. J. Wildlife Dis., 21:417-425.

Hellgren, E. C., R. L. Lochmiller, M. W. Thomas, and W. E. Grant. 1984. Cyclopia, congenital limb deformity, and osteomyelitis in the collared peccary, Tayassu tajacu (L.). J. Wildlife Dis., 20:354-357.

HENKE, S. E., AND S. DemaraIS. 1990. Effect of diet on condition indices in black-tailed jackrabbits. J. Wildlife Dis., 26:28-33.

HENKE, S. E., D. B. PEnCE, S. Demarais, AND J. R. Johnson. 1990. Serological survey of selected zoonotic disease agents in black-tailed jack rabbits from western Texas. J. Wildlife Dis., 26:107-111.

Hess, W. R., R. G. Endris, T. M. Haslett, M. J. Monahan, and J. P. MCCoy. 1987. Potential arthropod vectors of African swine fever virus in North America and the Caribbean basin. Vet. Parasit., 26:145-155.

HOLMAN, P. J., K. A. WALDRUP, AND G. G. WAGNER. 1988. In vitro cultivation of a Babesia isolated from a white-tailed deer (Odocoileus virginianus). J. Parasit., 74:111-115.

Hunt, L. M., AND B. N. GiLBERT. 1981. Ticks found on white-tailed deer from different ecological areas of Texas. Southwestern Ent., 6:341-345.

IKENGA, J. O., AND J. V. RiCheRSON. 1984. Trypanosoma cruzi (Chagas) (Protozoa: Kinetoplastida: Trypanosomatidae) in invertebrate and vertebrate hosts from Brewster County in Trans-Pecos Texas. J. Econ. Ent., 77:126-129.

Jones, R. H., R. O. Hayes, H. W. PotTeR, JR., AND D. B. FranCy. 1977. A survey of biting flies attacking equines in three states of the southwestern United States, 1972. J. Med. Ent., 14:441-447.

JONES, S. C., III. 1986. It's happening in Texas. Whalewatcher, 20:8-11.

KRANTZ, G. W., AND J. O. WhITAKER, JR. 1988. Mites of the genus Macrocheles (Acari: Macrochelidae) associated with small mammals in North America. Acarologia, 29:225-259. 
Lang, J. T., AND W. F. Chamberlain. 1986. Methoprene dust for flea (Siphonaptera: Ceratophyllidae) suppression on ground squirrels (Rodentia: Sciuridae). J. Med. Ent., 23:141145.

La Regina, M., J. Lonigro, AND M. WallaCe. 1986. Francisella tularensis infection in captive, wild caught prairie dogs. Lab. Anim. Sci., 36:178-180.

LEDUC, J. W., G. A. SMITH, AND K. M. JohnSON. 1984. Hantaan-like viruses from domestic rats captured in the United States. Amer. J. Trop. Med. Hygiene, 33:992-998.

LEFFINGWELL, L. M. AND S. U. NEILL. 1989. Naturally acquired rabies in an armadillo (Dasypus novemcinctus) in Texas. J. Clin. Microbiol., 27:174-175.

Leveson, J. E., A. J. Marengo-Rowe, R. L. Dotson, AND J. E. UbelaKer. 1989. Hermatology of cotton rats, Sigmodon hispidis, infected with Parastrongylus costaricensis (Metastrongyloidea: Angiostrongylidae). Trans. Amer. Micros. Soc., 108:380-386.

LEWIS, R. E., AND N. WILSON. 1982. A new species of Nycteridopsylla (Siphonaptera: Ischnopsyllidae) from southwestern United States, with a key to the North American species. J. Med. Ent., 19:605-614.

Lochmiller, R. L., E. C. Hellgren, P. G. Hannon, W. E. Grant, and R. M. Robinson. 1985. Coccidioidomycosis (Coccidioides immitis) in the collared peccary (Tayassu tajacu: Tayassuidae) in Texas. J. Wildlife Dis., 21:305-309.

Loomis, R. B. 1971. The genus Euschoengastoides (Acarina: Trombiculidae) from North America. J. Parasitol., 57:689-707.

LU, Y. S., J. REHG, AND G. LAWTON. 1982. Acute hepatitis in an opossum (Didelphis virginiana) infected with Salmonella turnidorp. Lab. Anim. Sci., 32:193-194.

MACKENZIE, W. F., L. S. MAGILL, AND M. HULSE. 1981. A filamentous bacterium associated with respiratory disease in wild rats. Vet. Path., 18:836-839.

Malek, E. A., R. B. Short, W. H. Teehan, AND A. JamA. 1987. Differential susceptibility of snail hosts to Heterobilharzia americana from Texas and Louisiana. J. Parasit., 73:872-873.

MARTIN, J. L., AND D. G. HuFFMAN. 1980. An analysis of the community and population dynamics of the helminths of Sigmodon hispidis (Rodentia: Cricetidae) from three central Texas vegetational regions. Proc. Helm. Soc. Washington, 47:247-255.

MCAllister, C. T. 1989. First record of Corrodopsylla hamiltoni (Siphonaptera: Hystrichopsyllidae) in Texas. Southwestern Nat., 34:561-563.

MCAllister, C. T., AND S. J. UPTON. 1988. Eimeria taylori n. sp. (Apicomplexa: Eimeriidae) and E. baiomysis from the northern pygmy mouse, Baiomy's taylori (Rodentia: Cricetidae), from Texas, U.S.A. Trans. Amer. Micros. Soc., 107:296-300.

1989a. Isospora peromysci Davis, 1967 (Apicomplexa: Eimeriidae) in Peromyscus leucopus and $P$. maniculatus (Rodentia: Cricetidae) from Texas. J. Protozool., 36:175-176.

1989b. Eimeria cryptotis n. sp. (Apicomplexa: Eimeriidae) from the least shrew, Cryptotis parva (Insectivora: Soricidae), in north-central Texas. J. Parasit., 75:212-214.

1989c. Eimeria lancasterensis (Apicomplexa: Eimeriidae) from the eastern fox squirrel, Sciurus niger (Rodentia: Sciuridae) in north-central Texas. J. Parasit., 75:642-644.

MCCONNELl, S., J. C. MORRILl, AND C. W. LivingSTON, JR. 1985. Use of a quadrivalent modified-live bluetongue virus vaccine in wildlife species. Prog. Clin. Biol. Res., 178:631638.

MCDANIEL, B. 1979. Host records of ectoparasites from small mammals of South Dakota. Southwestern Nat., 24:689-691.

MCHugh, C. P., M. GröGl, AND S. F. KerR. 1990. Isolation of Leishmania mexicana from Neotoma micropus collected in Texas. J. Parasit., 76:741-742.

McMurray, D. N., AND L. H. Russell. 1982. Contribution of bats to the maintenance of Histoplasma capsulatum in a cave microfocus. Amer. J. Trop. Med. Hyg., 31:527-531. 
Mercer, S. H., L. P. Jones, J. H. Rappole, D. Twedt, L. L. LaAck, and T. M. Craig. 1988. Hepatozoon sp. in wild carnivores in Texas. J. Wildlife Dis., 24:574-576.

MoOdy, J. K., E. C. HELlGREN, AND D. R. SYNATZSKE. 1990. Incidence of trichinosis in javelina from the Chaparral Wildlife Management Area. Caesar Kleberg Res. Prog. Wildlife Ecol., Ann. Rept. Texas Agric. Exp. Sta., pp. 25-26.

NAZARRO, W., JR. 1979. Survey of Trichuris vulpis infection in pound dogs from central Texas. Southwestern Vet., 32:105-107.

Oliver, J. H., JR., AND R. L. OSBURN. 1985. Cytogenetics of ticks (Acari: Ixodoidea): Chromosomes and timing of spermatogenesis in Amblyomma inornatum. J. Parasit., 71:124-126.

Osborn, D., S. Demarais, AND J. CORN. 1988. Disease survey of native and exotic big game in the Edwards Plateau. Research Highlights-1988, Noxious Brush and Weed Control, Texas Tech Univ., 19:32-33.

Parent, L. 1989. Lyme disease comes to Texas. Texas Parks and Wildlife, 47:18-22.

PARKER, O. S., AND A. H. ChANEY. 1979. Liomys irroratus (Rodentia: Heteromyidae), a new host for Cuterebra fontinella (Diptera: Cuterebridae). J. Med. Ent., 15:573.

PENCE, D. B. 1990. Helminth community of mammalian hosts: concepts at the infracommunity, component and compound community levels. Pp. 233-260, in Parasite communities: patterns and processes (G. W. Esch, A. O. Bush, and J. M. Aho, eds.), Chapman and Hall, New York, 335 pp.

PenCE, D. B., AND G. G. GRAY. 1981. Elaeophorosis in barbary sheep and mule deer from the Texas panhandle. J. Wildlife Dis., 17:49-56.

PenCE, D. B., AND L. A. WindBerg. 1984. Population dynamics across selected habitat variables of the helminth community in coyotes, Canis latrans, from south Texas. J. Parasit., 70:735-746.

PENCE, D. B., J. M. CRUM, AND J. A. ContI. 1983. Ecological analyses of helminth populations in the black bear, Ursus americanus, from North America. J. Parasit., 69:933-950.

PENCE, D. B., J. W. CuSTER, AND C. J. CARLEY. 1981. Ectoparasites of wild canids from the Gulf Coastal prairies of Texas and Louisiana. J. Med. Ent., 18:409-412.

Pence, D. B., F. D. MatThews, III., AND L. A. WindberG. 1982. Notoedric mange in the bobcat, Felis rufus, from south Texas. J. Wildlife Dis., 18:47-50.

Pence, D. B., F. F. KNOWLton, AND L. A. WindBerg. 1988. Transmission of Ancylostoma caninum and Alaria marcianae in coyotes (Canis latrans). J. Wildlife Dis., 24:560-563.

Pence, D. B., L. A. WindberG, B. C. Pence, ANd R. Sprowls. 1983. The epizootiology and pathology of sarcoptic mange in coyotes, Canis latrans, from south Texas. J. Parasit., 69:1100-1115.

Pence, D. B., R. M. Tran, M. L. Bishop, And S. H. Foster. 1983. Fibroma in a nine-banded armadillo (Dasypus novemcinctus). J. Comp. Path., 93:179-184.

Pfaffenberger, G. S., AND T. L. Best. 1989. Trichurus elatoris sp. n. (Nematoda: Trichuridae) from the Texas kangaroo rat (Dipodomys elator). Proc. Helm Soc. Washington, 56:76-81.

Pomeroy, L. V., AND R. B. LoOmis. 1984. A new genus of trombuline chiggers (Acari: Trombiculidae) from western North America. J. Med. Ent., 21:268-273.

POOL, G. E., AND C. S. HACKER. 1982. Geographic and seasonal distribution of rabies in skunks, foxes and bats in Texas. J. Wildlife Dis., 18:405-418.

PORTER, S. L. 1979. Microsporum gypseum infection in three Mexican prairie dogs. Vet. Med. Small Anim. Clin., 74:71-73.

Price, T. C., M. H. Dresden, T. Alvarado, J. Flanagan, and C. L. Chappell. 1989. Coenuriasis in a spectacled langue (Presbytis obscura): Praziquantel treatment and the antibody response to cyst antigens. Amer. J. Trop. Med. Hygene, 40:514-420. 
QURESHI, T., AND T. M. CRaIG. 1987. Control of the deer liver fluke at the Welder Wildlife Refuge. Welder Wildlife Found. Biennial Rept., pp. 12-13.

1989. Control of fascioloidiasis in deer on the Welder Wildlife Refuge. Welder Wildlife Found. Biennial Rept., p. 20.

QURESHI, T., AND D. S. DAVIS. 1984. The use of albendazole treated feed to control liver flukes in white-tailed deer. Caesar Kleberg Res. Prog. Wildlife Ecol., Ann. Rept. Texas Agric. Exp. Sta., pp. 19-20.

1985. The use of albendazole-treated feed to control deer liver fluke infections in captive white-tailed deer. Welder Wildlife Found. Biennial Rept., p. 13.

QUREShI, T., T. M. CRAIG, D. L. Drawe, AND D. S. DaVIS. 1989. Control of fascioloidiasis in deer on the Welder Wildlife Refuge: a preliminary report. P. 15, in Twelfth Ann. Meeting Southeast Deer Study Group, Oklahoma City, 22 pp.

1989. Efficacy of triclabendazole against fascioloidiasis (Fascioloides magna) in naturally infected white-tailed deer (Odocoileus virginianus). J. Wildlife Dis., 25:378-383.

RADOMSKI, A. A., AND D. B. PENCE. 1988. Hookworm morbidity and mortality in coyotes: an experimental study. Research Highlights-1988, Noxious Brush and Weed Control, Texas Tech Univ., 19:37-38.

Radomski, A. A., D. A. Osborn, D. B. Pence, M. Nelson, and R. J. Warren. 1988. Visceral helminths from an insular population of armadillos. Research Highlights-1988, Noxious Brush and Weed Control, Texas Tech Univ., 19:38.

Rawlings, J. A. 1986. Lyme disease in Texas. Zentral. Bacteriol. Microbiol. Hygiene, A263:483-487.

RICHARD, R. D., AND R. R. GERRISH. 1983. The first confirmed field case of myasis produced by Chrysomya sp. (Diptera: Calliphoridae) in the continental United States. J. Med. Ent., 20:685.

Robinson, R. M. 1988. Wildlife disease in the open range environment. Proc. 1988 Internat. Ranchers Roundup, San Antonio, pp. 100-102.

SChafFer, G. D., W. R. DAVIDSON, V. F. NeTtles, AND E. A. Roller, III. 1981. Helminth parasites of translocated raccoons (Procyon lotor) in the southeastern United States. J. Wildlife Dis., 17:217-227.

SHANE, S. 1978. Suckerfish attached to a bottlenose dolphin in Texas. J. Mamm., 59:439-440.

SHORT, J. A., L. F. MAYBERRY, AND J. R. BRISTOL. 1980. Eimeria chihuahuaensis sp. n. and other coccidia from Dipodomys spp. in El Paso County, Texas. J. Protozool., 27:361-364.

Smith, J. H., D. S. Folse, E. G. Long, J. D. Christie, D. T. Crouse, S. K. File, and M. T. Kelly. 1983. Leprosy in wild armadillos (Dasypus novemcinctus) of the Texas Gulf Coast: epidemiology and mycobacteriology. J. Reticuloendothelial Soc., 34:75-88.

Stewart, G. L., W. G. SMYTh, AND J. J. RedDington. 1979. Canine infection with Dirofilaria immitis in North Texas, U.S.A. Southwestern Vet., 32:199-202.

STOUT, C. A., AND D. W. DUSZYNSKI. 1983. Coccidia from kangaroo rats (Dipodomys spp.) in the western United States, Baja California, and northern Mexico with descriptions of Eimeria merriami sp. n. and Isospora sp. J. Parasitol., 69:209-214.

Stubblefield, S. S., D. B. PENCE, AND R. J. WARREN. 1987. Visceral helminth communities of sympatric mule and white-tailed deer from the Davis Mountains of Texas. J. Wildlife Dis., 23:113-120.

TABOR, S. P. 1986. The occurrence of plague (Yersinia pestis) in a bobcat from the Trans-Pecos area of Texas. Southwestern Nat., 31:135-136.

TANIGOSHI, L. K., AND R. B. Loomis. 1974. The genus Hyponeocula (Acarina, Trombiculidae) of western North America. Melanderia, 17:1-27. 
TEWES, M. E., L. L. LAACK, AND R. D. BLUETT. 1989. Diseases and physiological profiles of ocelots. Caesar Kleberg Res. Prog. Wildlife Ecol., Ann. Rept. Texas Agric. Exp. Sta., p. 30.

ThOMAS, H. H., J. O. WhitAKER, JR., AND T. L. BEST. 1990. Ectoparasites of Dipodomys elator from north-central Texas with some data from sympatric Chaetodipus hispidis and Perognathus flavus. Southwestern Nat., 35:111-114.

Thomas, N. J., W. J. Foreyt, J. F. Evermann, L. A. WindBerg, AND F. F. KNOwLton. 1984. Seroprevalence of canine parvovirus in wild coyotes from Texas, Utah, and Idaho (19721983). J. Amer. Vet. Med. Assoc., 185:1283-1287.

ThOMAS, R. E. 1988. A review of flea collections from Onychomys leucogaster with observations on the role of grasshopper mice in the epizoology of wild rodent plague. Great Basin Nat., 48:83-95.

Timm, R. M. 1983. Fahrenholz's rule and resource tracking: a study of host-parasite coevolution. Pp. 225-265, in Coevolution (H. M. Nitecki, ed.), Univ. Chicago Press, 392 pp.

Ubelaker, J. E., J. Caruso, and A. Pena. 1981. Experimental infection of Sigmodon hispidis with third-stage larvae of Angiostrongylus costaricensis. J. Parasit., 67:219-221.

WAID, D. D., AND D. B. PENCE. 1987. Helminth parasites of mountain lions from southwestern Texas. Research Highlights-1987, Noxious Brush and Weed Control, Texas Tech Univ., 18:35.

1988. Helminths of mountain lions (Felis concolor) from southwestern Texas, with a redescription of Cylicospirura subaequalis (Molina, 1860) Vevers, 1922. Canadian J. Zool., 66:2110-2117.

WAID, D. D., D. B. PENCE, AND R. J. WARREN. 1985. Effects of season and physical condition on the gastrointestinal helminth community of white-tailed deer from the Edwards Plateau. J. Wildlife Dis., 21:264-273.

WAID, D. D., R. J. WARREN, AND D. B. PENCE. 1984. Elaeophora schneideri Wehr and Dickmans, 1935 in white tailed-deer from the Edwards Plateau of Texas. J. Wildlife Dis., 20:342-345.

WALDRUP, K. A., A. A. KOCAN, AND G. G. WAGNER. 1989. Epidemiology of Babesia odocoilei infection in white-tailed deer (Odocoilius virginianus). P. 22, in Twelfth Ann. Meeting Southeast Deer Study Group, Oklahoma City, 22 pp.

Waldrup, K. A., E. Collisson, S. E. Bentsen, C. K. Winkler, and G. G. Wagner. 1989. Prevalence of erythrocytic protozoa and serologic reactivity to selected pathogens in deer in Texas. Prev. Vet. Med., 7:49-58.

Waldrup, K. A., A. A. Kocan, T. Qureshi, D. S. Davis, D. BagetT, and G. G. Wagner. 1989. Serological prevalence and isolation of Babesia odocoilei among white-tailed deer (Odocoileus virginianus) in Texas and Oklahoma. J. Wildlife Dis., 25:194-201.

WALSH, G. P., W. M. MEYERS, AND C. H. BINFORD. 1986. Naturally acquired leprosy in the ninebanded armadillo: a decade of experience 1975-1985. J. Leukocyte Biol., 40:645-656.

WebB, J. P., JR., AND R. B. Loomis. 1977. Ectoparasites. Pp. 57-119, in Biology of bats of the New World family Phyllostomatidae. Part II (R. J. Baker, J. K. Jones, Jr., and D. C. Carter, eds.), Spec. Publ. Mus., Texas Tech Univ., 13:1-364.

Whitaker, J. O., D. A. EASTERla, AND A. Fain. 1987. First records of the mite, Ewingana (Doreyana) doreyae Dusbabek 1968 (Acarina, Myobbidae) from the United States with notes on streblid flies from Big Bend National Park, Texas. Southwestern Nat., 32:505.

WiLson, G. T., D. GARIPPA, R. SHAKE, AND A. MANIS. 1981. A search of wood rat (Neotoma) nests in Taylor and Jones counties, Texas, for the presence of Reduviidae infected with Trypanosoma cruzi. Southwestern Nat., 25:565-566.

Wilson, G. T., P. Horton, W. C. Stevens, AND R. E. ShaKe. 1984. Absence of leprosy-like disease in the nine-banded armadillo (Dasypus novemcinctus) in and around Taylor County, Texas. Texas J. Sci., 36:73-79. 


\section{OTHER STUdies}

Adams, C. E., AND J. K. Thomas. 1983. Characteristics and opinions of Texas hunters. Proc. Southeastern Assoc. Fish Wildlife Agencies, 37:244-251.

AHRNS, J. 1982. Nonconsumptive wildlife issues. Pp. 83-91, in Texas wildlife resources and land use (J. T. Baccus, ed.), Texas Chap. Wildlife Soc., 199 pp.

BAKER, R. H. 1986. Barn owl prey selection: 1938 and 1984. Southwestern Nat., 31:401.

BEST, M. S., AND R. M. Whiting, JR. 1990. Trapping-induced changes in scent-station visits by opossums and raccoons. Manag. Wildlife Southwest Symp., Tucson, Arizona, pp. 94-99.

Bryant, F. C. 1989. Economic implications of wildlife. Proc. Western Sec., Amer. Soc. Animal Sci., 40:500-502.

EVERITT, J. H., AND M. A. AlANIZ. 1981. Nutrient content of cactus and woody plant fruits eaten by birds and mammals in South Texas. Southwestern Nat., 26:301-305.

FLICKINGER, E. L. 1981. Wildlife mortality at petroleum pits in Texas. J. Wildlife Manag., 45:560-564.

GoYer, N., A. L. BARR, AND A. R. P. JouRnET. 1981. Barn owl pellet analysis in north-western Harris County, Texas. Southwestern Nat., 26:202-204.

GunN, S. J., AND D. J. SChmidLy. 1984. Preventing nutria damage to seismic cables with chemical and physical deterrents. Texas J. Sci., 36:205-213.

GUTHERY, F. S., E. G. Bolen, AND F. A. STORMER. 1982. Wildlife research programs, goals and issues. Pp. 142-156, in Texas wildlife resources and land use (J. T. Baccus, ed.), Texas Chap. Wildlife Soc., 199 pp.

HAMILTON, K. L., AND R. L. NeILL. 1981. Food habits and bioenergetics of a pair of barn owls and owlets. Amer. Midland nat., 106:1-9.

INGLIS, J. M. 1985. Wildlife management and IBMS. Integrated brush management systems for South Texas: development and implementation. Bull. Texas Agric. Exp. Sta., 1493:35-40.

Killion, M. J., AND W. E. GRANT. 1989. Grassland small mammal community response to red imported fire ant invasion. Welder Wildlife Found. Biennial Rept., p. 17.

LAFFERTY, L. A., AND M. E. TeWES. 1988. Use of Conservation Reserve Program habitats by selected wildlife populations. Caesar Kleberg Res. Prog. Wildlife Ecol., Ann. Rept. Texas Agric. Exp. Sta., p. 37.

LEVERICH, W. J. 1983. Pocket gophers, tanks, and plant community composition. Southwestern Nat., 28:378.

MANNING, R. M., AND J. K. JONES, JR. 1990. Remains of small mammals recovered from barn owl pellets from Crosby County, Texas. Texas J. Sci., 42:311-312.

Masser, M. P., AND W. E. Grant. 1986. Fire ant-induced trap mortality of small mammals in east-central Texas. Southwestern Nat., 31:540-542.

MEENAKSHI, N., AND L. D. FLAKE. 1987. Impact of cattle grazing systems on rodent and cottontail rabbit populations in South Texas. Welder Wildlife Found. Biennial Rept., p. 12.

Mueller, A. J. 1985 . Vertebrate use of nontidal wetlands on Galveston Island, Texas. Texas J. Sci., 37:215-225.

Pesaturo, R. J., R. W. ManNing, AND J. K. Jones, JR. 1989. Small mammals captured by barn owls in Lamb County, Texas. Texas J. Sci., 41:433-434.

RAPPOLE, J. H. 1985. The remote-trip camera as a survey device for wildlife. Caesar Kleberg Res. Prog. Wildlife Ecol., Ann. Rept. Texas Agric. Exp. Sta., pp. 34-35.

Rhodes, M. J., T. J. Cloud JR., AND D. HAAG. 1983. Habitat evaluation procedures for planning surface mine reclamation in Texas. Wildlife Soc. Bull., 11:222-232.

RidLEHUBER, K. T., AND N. J. Silvy. 1981. Texas rat snake feeds on Mexican freetail bat and wood duck eggs. Southwestern Nat., 26:70-71. 
SHUPE, T. E., AND F. S. GUTHERY. 1983. Irrigation effects on Texas High Plains wildlife. Research Highlights-1983, Noxious Brush and Weed Control, Texas Tech Univ., 14:40.

STANGL, F. B., JR., AND E. M. JONES. 1987. An assessment of geographic and seasonal biases in systematic mammal collections from two Texas universities. Texas J. Sci., 39:129-137.

STEELE, D. G., K. E. BYRD, L. MCNATT, AND G. VENT. 1984. Human and non-human skeletal remains recovered from Sorcerer's Cave, Terrell County, Texas. Texas J. Sci., 36:169-184.

TEER, J. G. 1982. Texas wildlife: now and for the future. Pp. 9-20, in Texas wildlife resources and land use (J. T. Baccus, ed.), Texas Chap. Wildlife Soc., 199 pp.

WHITING, JR., R. M., AND R. R. FLEET. 1985. Small animal population inventories in a mixed pinehardwood forest of East Texas. USDA-Forest Service, Southern Forest Exp. Sta., Range Manag. Res., 19-330, CRIS no. FS-SO-1701-4.11, 396 pp.

WhitING, JR., R. M., R. R. FLEET, AND H. A.PEARSON. 1983. Implementing and maintaining a system to monitor small mammal and bird populations. Proc. Internat. Conf. Renewable Resource Inventories for Monitoring Changes and Trends, Corvallis, Oregon, pp. 420-424.

WhitTAKeR, D. G., S. DEMARAIS, AND M. T. Pollock. 1988. A computer package for analyzing habitat use by wildlife. Research Highlights-1988, Noxious Brush and Weed Control, Texas Tech Univ., 19:29.

- 1989. A computer package for analysis of habitat use by wildlife. Research Highlights-1989, Noxious Brush and Weed Control, Texas Tech Univ., 20:32-33.

WIGGERS, E. P., AND S. L. BEASOM. 1981. A land surface ruggedness index for wildlife habitat analysis. Research Highlights-1981, Noxious Brush and Weed Control, Texas Tech Univ., 12:70-71.

\section{Literature Cited}

JONES, J. K., JR., AND J. A. HoMAN. 1976. Contribution to a bibliography of Recent Texas mammals, 1961-1970. Occas. Papers Mus., Texas Tech Univ., 41:1-21.

JONES, J. K., JR., C. J. YOUNG, AND D. J. SChMIDLY. 1985. Contribution to a bibliography of Recent Texas Mammals, 1971-1980. Occas. Papers Mus., Texas Tech Univ., 95:1-44.

Raun, G. G. 1962. A bibliography of the Recent mammals of Texas. Bull. Texas Mem. Mus., 3:xi $+1-81$.

Address of authors: The Museum and Department of Biological Sciences, Texas Tech University, Lubbock 79409 (JKJ); Department of Range and Wildlife Management, Texas Tech University; Lubbock 79409 (SD); Department of Veterans Affairs Medical Center, Renal Metabolic Laboratory (151-G), 4500 South Lancaster Road, Dallas, Texas 75216 (CTM).

Professor J. Knox Jones, Jr. edited the Special Publication series from its inception in 1972 until his death in 1992. 


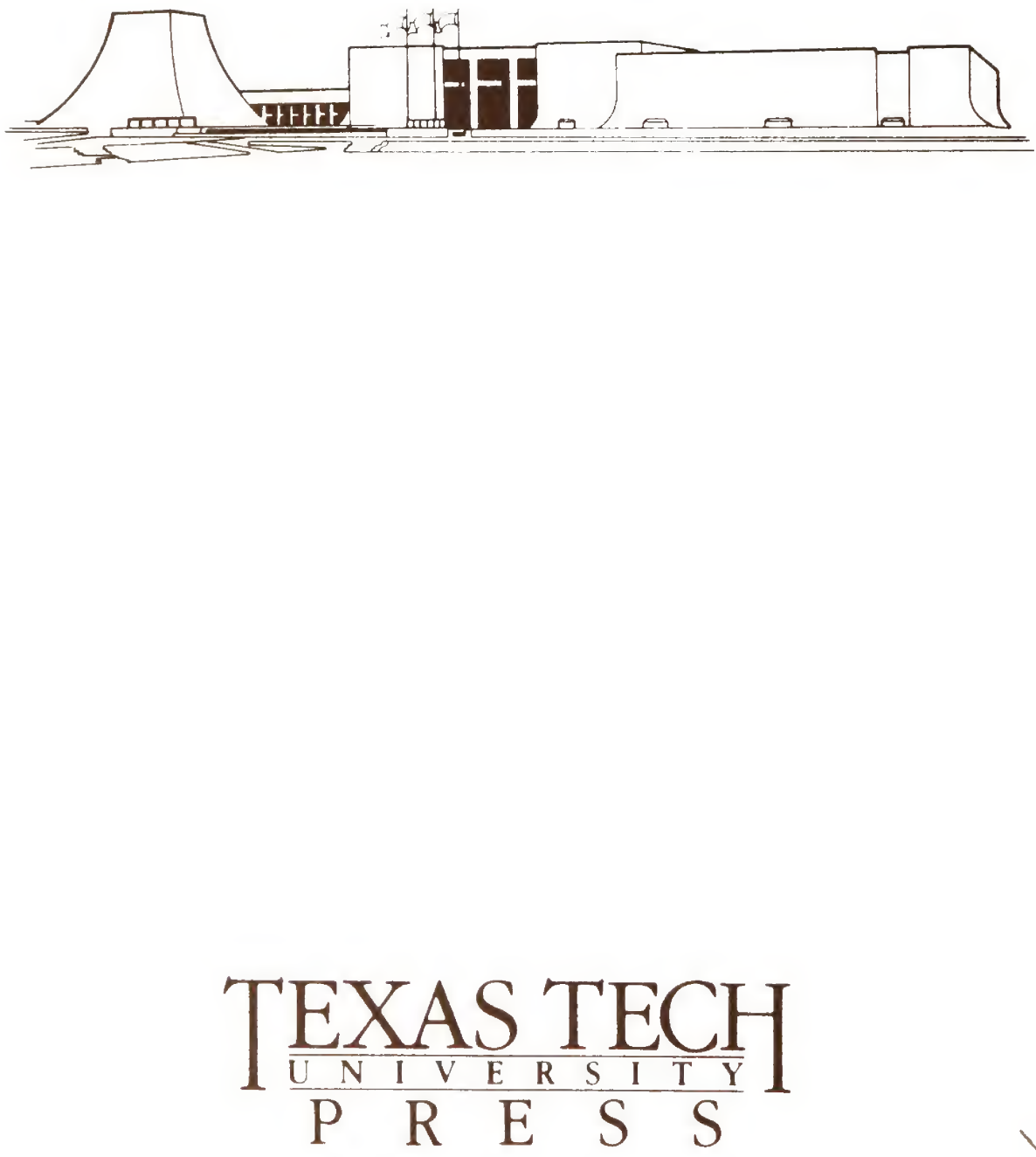